\title{
LATE ROMAN POTTERY FROM ROOM III/NORTH AT THE VISEGRÁD-GIZELLAMAJOR FORT
}

\author{
KATALIN OTTOMÁNYI
}

\author{
Ferenczy Museum Centre \\ 5., Kossuth Lajos Str, H-2000 Szentendre, Hungary \\ ottomanyi.katalin@gmail.com
}

\begin{abstract}
Pottery at the late Roman fort of Visegrád-Gizellamajor contains both forms common in the $4^{\text {th }}$ century as well as new ones, which appear at the turn of the $4^{\text {th }}$ and $5^{\text {th }}$ centuries. On traditional Roman household pottery and glazed vessels new surface ornaments (incised and notched) and new designs (fired yellowish-white, very gritty fabric) appear. Additionally, there are vessels with smoothed and smoothed-in ornaments. Although the excavators distinguished various layers in the fort, pottery from the layers often fit together. What survived to the greatest extent were the materials from the upper destruction debris. Room III of the north wing was a later addition to the fort; hence its pottery can be dated from the Valentinian period until the Hun period.
\end{abstract}

Keywords: Late Roman Period, Early Migration Period, pottery, Limes in Pannonia

\section{INTRODUCTION}

On the north-eastern border of Pannonia, along the Danube Limes (the province of Valeria) was a dense line of forts and watchtowers during the second half of the $4^{\text {th }}$ century (Fig. 1.1). ${ }^{1}$ Part of this chain was the rectangular small fort excavated between 1988 and 2003 at Visegrád-Gizellamajor. The small fort lies between the forts of Pilismarót and Visegrád-Sibrik Hill, within sight of the neighbouring watchtowers. Strategically, it was in the best location for sighting and defending against attacks by the Quadi from across the Danube, as well as for controlling trade across the river.

There were fan-shaped towers at the four corners of the fort. Attached to its main walls, on the inside, sidewings (6 metres wide) were built, symmetrically enclosing the inner drill ground. Its gate was on the northern side, facing the Danube. The gate is now partly underneath modern-day Route 11 (Fig. 1.2). ${ }^{2}$

Its construction can be dated to the mid- $4^{\text {th }}$ century, the reign of Constantius II. Remodelling during the Valentinian period can be detected throughout the fort, while at the turn of the $4^{\text {th }}$ and $5^{\text {th }}$ centuries only smaller rooms are attached to the main wings. The stratigraphic position of the latest buildings shows that they were built after the partial destruction of the fort. It was used according to its intended purpose until the 430s, after which it served as a burial site (and perhaps dwelling) of the Huns.

The analysis of the pottery, given the immense quantity, is carried out wing by wing, room by room. ${ }^{3}$ The present study presents the materials from room III of the north wing. This is simply due to the quantity of the mate-

${ }^{1}$ SOPRONI 1985; VISY 2003.

${ }^{2}$ The small fort was excavated by the archaeologists of the King Matthias Museum Visegrád, Péter Gróf and Dániel Gróh. GRóFGRÓH 1995; GRÓF-GRÓH-MrÁv 2001-2002; GRÓH 2000; GRÓH 2006.
${ }^{3}$ West wing: OTTOMÁNYi 2012 and OTTOMÁNYi 2015b; South wing: OTTOMÁNYI 2015a; Courtyard: OTTOMÁNYI 2018a; NW corner tower: OTTOMÁNYI 2018b; Room I North: OTTOMÁNYI 2018c.

Acta Archaeologica Academiae Scientiarum Hungaricae 71 (2020) 15-70

C 2020 The Author 

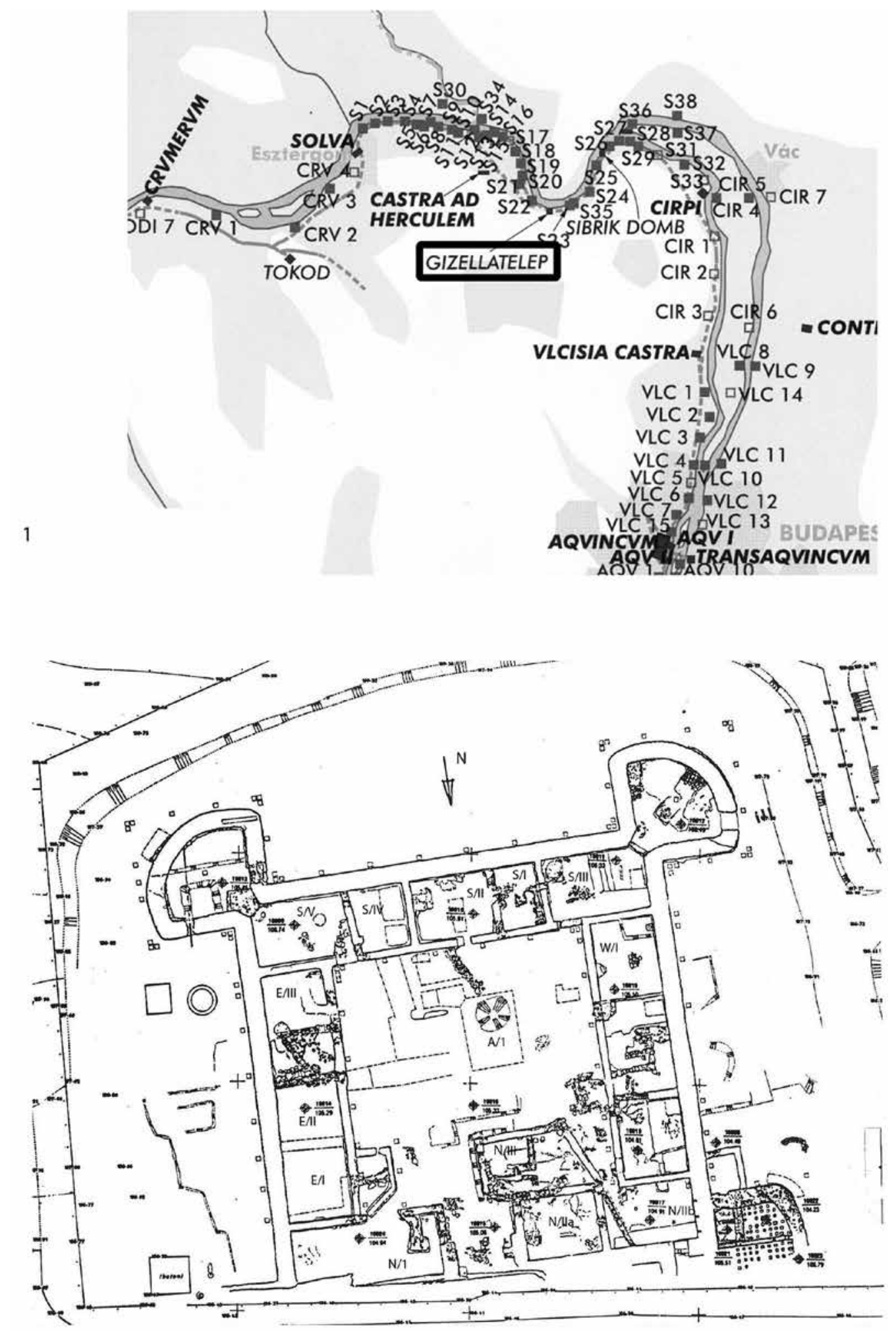

2

Fig. 1. 1: Late Roman forts in the Danube Bend between Solva and Aquincum (VISY 2003); 2: The ground plan of the fort uncovered in Visegrád-Gizellamajor 
rial, as its nature, forms and types cannot be separated from those in other parts of the wing; indeed there are fragments which match pieces from rooms I/N and IIb/N as well as the western half of the courtyard.

\section{THE STRATIGRAPHY OF ROOM III NORTH}

The north wing was built facing the Danube, parallel to the river. This was the location of the small fort's entrance, which split the wing into two parts in the middle. Originally there was a room on each side of the gate $(\mathrm{I}-\mathrm{II} / \mathrm{N})$, from which the corner towers could be accessed. During later modifications, the rooms were split into two, fitted with heating flues, and two new trapezoid-shape rooms were built in front of them. Of these, room III/N narrowed the gate passage. ${ }^{4}$

Room III/N was built later than the fort itself (Period 2). Its original shape was probably rectangular, since the diagonal wall, which gave the room its trapezoid shape, postdates the stone wall of the lower heating flue. ${ }^{5}$ Its walls were of lower quality; within them ran a heating flue heated from an external furnace from the west (Fig. 2).

The excavators distinguished three layers in the room. The lower heating flue is built on the lowest, clayey layer (this layer is stony on the western side). When the flue was filled in, an intact, glazed jug and an assemblage of jewellery were hidden under the flue cover $\left(\right.$ Fig. 10.1). ${ }^{6}$ The upper heating flue system with a furnace (on the same level as the external furnace in the middle of the west wing) is built on top of the filled in flue. ${ }^{7}$ The upper, new floor is a hard, clayey - with mortar patches in places - floor (Period 3), on which stood a large stone mortar (at the end of the diagonal wall). Above it was the destruction debris with daub and mortar (Period 4).

In terms of absolute chronology, the room which narrowed the gate passage was likely constructed during the remodelling, i.e. during the Valentinian period. ${ }^{8}$ The upper floor is later; it can be dated to the final third or end of the $4^{\text {th }}$ century. ${ }^{9}$ The upper destruction debris was the level of the first third of the $5^{\text {th }}$ century, when the room stopped being used in the 430s. In the Hun period a grave was dug into it (grave no. 94/1, in the western half of the room). ${ }^{10}$

\section{POTTERY BY LAYERS}

Separating pottery found in room III/N from those from room II/N as well as the western and northern part of the courtyard is problematic. Initially the excavation diary records all rooms west of the gate together. It is only in autumn 1995 that the area in the southern foreground of room II/N is designated room III/N. ${ }^{11}$ Altogether, I recorded 1045 fragments from room III/ $\mathrm{N}$ and its surroundings.

${ }^{4}$ GRÓF-GRÓH 1995, 65-66; GRÓH 2000, 20, 28; The other trapezoid-shape room was built in front of room I East and room I North on the mortared pavement of the courtyard, block the entrance of room $\mathrm{I} / \mathrm{N}$.

${ }^{5}$ GRÓH 2000, 20: the originally rectangular room became trapezoid shaped after the construction of the upper heating flue. The new floor, above the old flue, was built onto the western wall of this building.

${ }^{6}$ Military brooch, clasp, beads (including amber beads); somewhat farther: double-sided bone comb (GRÓH 2000, 28, Fig. 1.3).

${ }^{7}$ The daub debris and black timber beams are on the same level as the top of the lower flue (Fig. 2.2). On the bags there are materials from above the upper mortary layer and the upper clayey layer. This was likely the floor above the new heating-flue. Based on the above, the diagonal west wall would belong to the late-fourthcentury remodelling. However, the diagonal wall in room $\mathrm{IIb} / \mathrm{N}$ (which runs in the same direction) is recorded as a NW-SE wall connected with the lower floor, built on clay, above which the next floor was constructed (GRÓH 2000, 19).

${ }^{8}$ In room III/N several coins of Valens and a few of Constantius II were found, without closer identification of the layer. The earliest is a coin of Constantine II (337-341) from the mortary layer between rooms III/N and I/W. In the SE corner of the room was a brick fragment with a QUADRIBURG stamp.

${ }^{9}$ This may correspond to period D1 used in the research of the Migration Period. The upper destruction debris may correspond to horizon D2. See BIERBAuER 2015, 374 (Bierbauer D1: 370/380_ 400/410; D2a: 400/410-420/430; D2b: 420/430-440/450; D3: 450/460-480/490; Tejral D1: 360/370-400/410; D2: 390/400430/440; D2/D3: 430-460; D3: 450-470/480).

${ }^{10}$ GRÓH 2000, Fig. 60 (with bronze buttons as grave goods).

${ }^{11}$ It is unclear whether the area between rooms I/W and II/N, excavated in 1994, was the western edge of room III/N or the western part of the courtyard (2013.14.1-4.). It may perhaps belong to room IIb/N. It contains materials that match those of rooms IIb/N and III/N, hence I am publishing them here (Fig. 5.1). By 1996 the diary writes clearly about the area between III/N and I/W. The external furnace heating room III/N was located here, in the courtyard between the two buildings (2013.14.10-11.). It was published as part of the western half of the courtyard (OTTOMÁNYI 2018a, 116). The gate passage to the north and the areas to its south and west, excavated between 1993 and 1996, too, cannot be always clearly connected with a particular room (foreground of the northern gate: 2013.14.20. and 22; 2018.1.13. and 15.). 

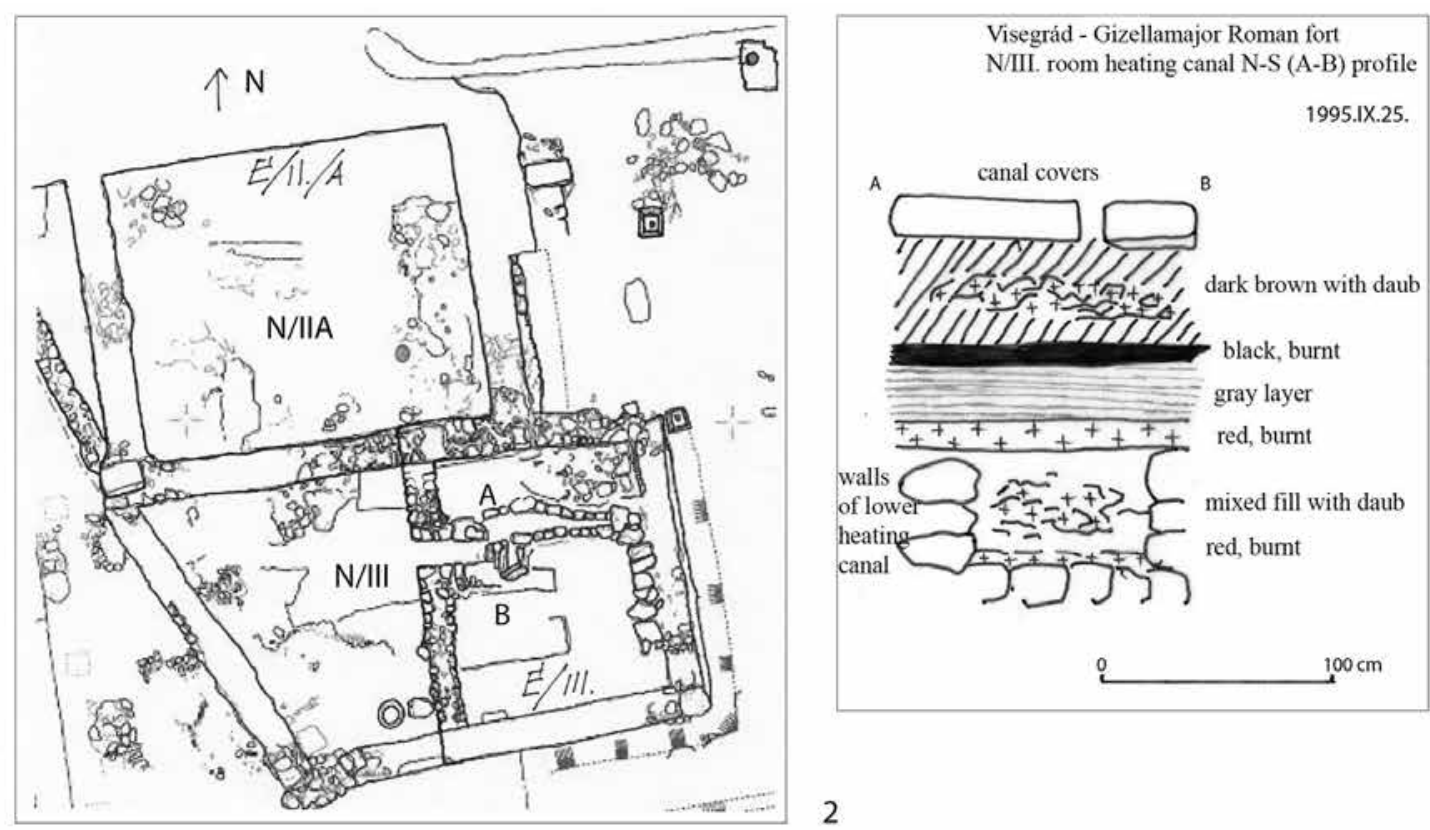

1
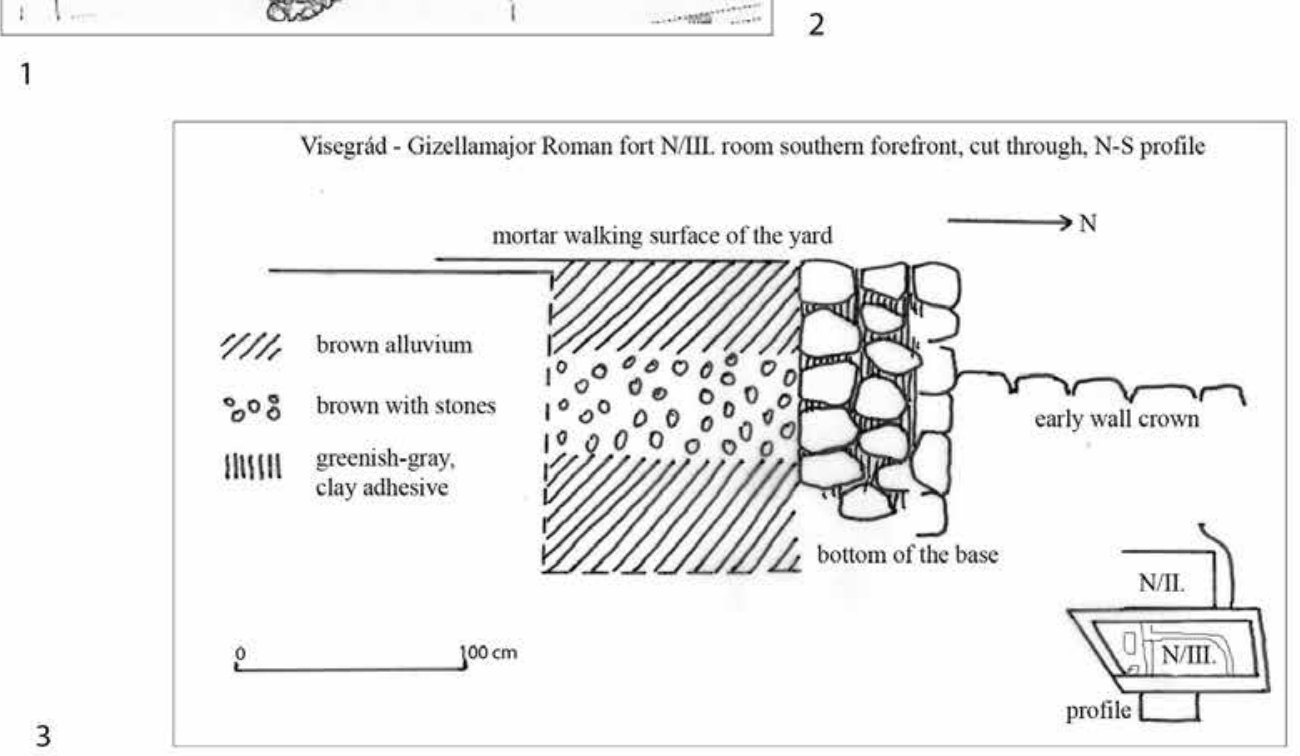

4

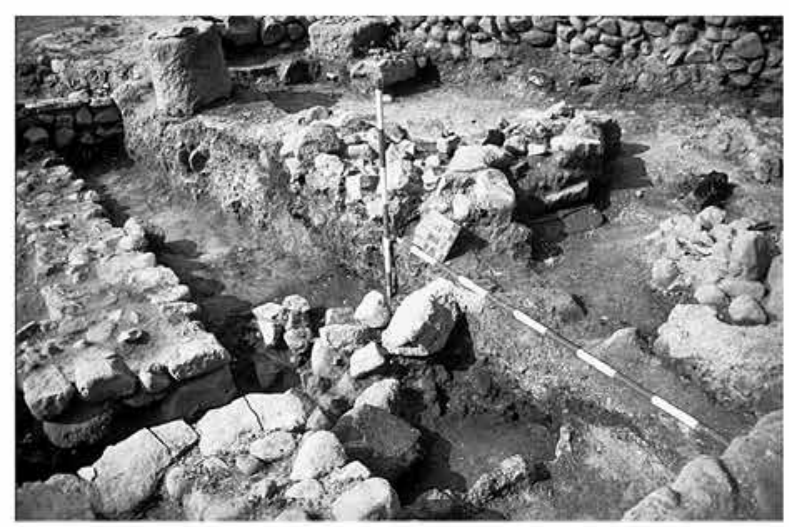

Fig. 2. Top view of room III/N $(1,4)$ and sections $(2 .:$ heating flue, $3 .:$ courtyard in front of the room's southern wall) Acta Archaeologica Academiae Scientiarum Hungaricae 71, 2020 
Room III/N was built during the remodelling of the fort (Period 2), therefore materials from before the Valentianian period could only appear here in a secondary context. Pottery could not be unequivocally connected with the lowest floor of the room. ${ }^{12}$ Belonging to the filling between the floors is perhaps the materials from the lower debris (2013.14.22.) and the daub debris above the lower clayey layer (2013.14.19.). In both we can find new-type household pottery and, among the lower debris, even smoothed-in vessels. The vessel and the assemblage of jewellery hidden inside the lower heating flue were buried during the late $4^{\text {th }}$ century remodelling (Period 3$)$. This is the only sealed layer; it is a pity that there were so few pieces of pottery in it (most being new-type household pottery). After the flue was filled in, a new, clayey, mortary floor was constructed above it (2013.14.7. and 12.). On this upper floor stood the stone mortar (2013.14.17.). During the excavation of the floor both smoothed-in and newtype household pottery were found. Most pieces of pottery in the room were found above it (upper yellowish-brown, upper stony brown, above the mortary layer, upper stone debris, upper daub). In this, latest period (Period 4), the whole fort is destroyed and filled in. The matching fragments in the daub layer may be the result of a deliberate infilling of the entire wing. The question is: by whom and when was it filled in?

\subsection{Pottery groups}

Based on the presence or absence of the various groups (early Roman pottery, glazed, smoothed-in, new, $5^{\text {th }}$ century pottery), I tried to distinguish pottery groups within the fort's material. ${ }^{13}$ This also meant chronological differences. Sometimes the pottery groups can be aligned with the layers (e.g. group IIa in the debris above the lower floor; group III in the upper daub). It is, however, more common that in the layers there is a mix of pottery from various groups, e.g. groups Ib and III in the upper debris, groups II-III in the layers above the upper floor etc. At times it even contradicts the stratigraphy, e.g. the latest group III in the lower debris (2013.14.22.). There are, therefore, no clear layers with connected pottery groups. This is a trend that lasts from the Valentinian period until the first half (or perhaps middle) of the $5^{\text {th }}$ century, and, as time progresses, more and more new-type pottery appears in the debris, while the amount of $4^{\text {th }}$ century pottery decreases.

Group Ia: mixed early and late Roman pottery. Typical $4^{\text {th }}$ century household pottery, few hand-made (no smoothed or glazed). See 2013.14.16. (layer uncertain).

Group Ib: no early Roman pottery. $4^{\text {th }}$ century glazed, smoothed, and household pottery. 2013.14.14. (upper debris) and 2013.14.18. (stone debris). Period 4.

Group IIa: In addition to $4^{\text {th }}$ century glazed and household pottery, also smoothed-in pottery group 2 or late smoothed (few early pottery and some can be later, household pottery): 2013.14.12. (excavation of the floor), 2013.14.13. (stone debris), 2013.14.17. (layer with the stone mortar), 2013.14.19. (daub debris above the lower clay layer). Period 2/3-4.

Group IIb or IIIb: $4^{\text {th }}$ century glazed, no smoothed-in, large amount of new-type household pottery (2013.14.7.: infill of the flue; 2018.1.15.: surface of the debris). Period 3-4.

Group IIc: $4^{\text {th }}$ century glazed (one piece possibly late), one late smoothed, no new-type household pottery (2013.14.15.: above the mortary layer). Period 3-4.

Group III: late glazed, smoothed-in, late smoothed, and new-type household pottery as well as hand-made materials. In some cases there is no late glazed only, smoothed-in, late smoothed and late household pottery (IIIa: 2013.14.5. 9.); no glazed or smoothed-in, only the household pottery represents the $5^{\text {th }}$ century (IIb or IIIb: 2013.14.7.; 2018.1.15.). Period 2/3-4.

Most of the pottery in room III/N belong to this group, although in some cases the $4^{\text {th }}$ century material still dominates and there are very few $5^{\text {th }}$ century vessels (3\%: 2013.14.2-4.). A third of the material may be new-type (28-36\%: 2013.14.1.,5.), but in most cases half of the material belongs to this kind of late pottery (2013.14.6. -7., 20., 22.; 2018.1.13., 15.).

\footnotetext{
${ }^{12}$ According to the excavation diary, in the furnace pit of lower level's heating flue there were fragments of a large barbarian vessel underneath the stone debris, as well as a small, squashed bronze
}

vessel, a millstone and burnt timber beams (diary: 1996.VIII.15.). So far, I have not seen this material.

${ }^{13}$ For more details on the groups see OTTOMÁNyi 2015a, 5-7. 
Its earliest layer is the lower debris (2013.14.22), but this, too, might already be post-Valentinian (Period 2-3). Most of the late material was found in the upper daub layer (Period 4). More than half (55-67.5\%) of the pottery from this layer is a new-type, $5^{\text {th }}$ century vessel. We have only one sealed layer - the infill of the lower heating flue (2013.14.7.) - where there was a conspicuously high amount of late household pottery (63.6\%), although the glazed vessels found next to them represent traditional, $4^{\text {th }}$ century forms (worn, leaky jug used for a long time). This sealed layer, which was formed through the construction of the new floor and flue above it (Period 3), dates the use of the following types: white; ribbed; with incised wave motifs; as well as the Leányfalu mug-pot type to the final quarter of the $4^{\text {th }}$ century the earliest or the turn of the $4^{\text {th }}$ and $5^{\text {th }}$ centuries.$^{14}$ Next to it, the military brooch and double-sided bone comb from the jewellery assemblage indicate that these vessels were used by a mixed group of Roman soldiers and a new, perhaps Germanic, populace (and their families).

\subsection{Matching fragments}

We can find matching fragments in the various parts of room III/N, and there are also matches with the material from rooms I/N and II/N and even in some cases with that of the west wing (see Table 1 ). ${ }^{15}$

Within room III/N: smoothed bowl fragments from the dark brown infill above the clay surface (2013.14.5.3.) and from a bag with an illegible label from room III/N (Fig. 7.1). From this same infill the fabric of a different smoothed bowl fragment (2013.14.5.12.) is very similar to that of a piece from above the clayey brown layer (2013.14.4.21.), so they may have belonged to the same vessel.

Room III/N and the western part of the courtyard: There is a glazed mortarium fragment from the daub debris of room III/N (2013.14.21.2.), which matches the material from above the clayey brown layer in the courtyard between the room and the west wing (2013.14.4.1.: Fig. 5.1). ${ }^{16}$

Room III/N and room I/N: the matching fragments of a white-slip vessel with a horizontal rim from the room's daub debris (2013.14.6.107.) and in the daub debris of the neighbouring room $\mathrm{I} / \mathrm{N}$ (2013.11.6.16.).

Room III/N and room II/N: from this same upper daub debris (2013.14.6.112.), a jug fragment with incised wave motifs matches the material from the upper $20-40 \mathrm{~cm}$ of room II/N (2013.12.1.10.: Fig. 13.4). A smoothed small bowl from the upper stony brown part between II/N and the west wing (2013.14.1.21.) matches the material from the infill above the clayey floor of room II/N (2013.13.23.4.: Fig. 7.5). The fragments of a smoothed-in jug come from the infill below and above the mortary floor of IIb/N (2013.13.2.+6.+9.+11.+16.), as well as room III/N (2013.14.23.1.: Fig. 8.1) ${ }^{17}$

Therefore, the upper debris (daub and greyish-brown) appeared at the same time on top of the walls of the entire wing. Moreover, there is a fragment from this northern daub debris, which fits with the material from the infill above the west wing's lower floor. ${ }^{18}$

Levelling in the north and west wing, therefore, took place at the same time. The question is: when? Perhaps when the original floor in room II/N was no longer in use, collapsed or decayed, it was filled up to form a level surface. ${ }^{19}$ Or, perhaps, when the lower-quality mud-brick walls were built on top and people were still living there (mixed Roman and Barbarian troops), or when these, too, were already levelled (by the Huns)? Since the material from the mud-brick debris, too, matches that of the layer below the floor (room IIb/N), the one from the ruins of these buildings may be the top layer of debris. This could only have happened at the end of occupation, during the first half of the $5^{\text {th }}$ century, or during the Hun period, when other ethnic groups settled among the ruins of the fort.

\footnotetext{
${ }^{14}$ In other parts of the fort there are a few such pieces already in the Period 2 layers from the Valentinian period (e.g. OTTOMÁNYI 2015a, 6-7: group III between layers 1-2, group IIIc: layer 2).

${ }^{15} \mathrm{Had}$ it been possible to lay out and compare the entire material, or at least that of the rooms of the various wings at the same time, there would be a much greater number of matching fragments. Now, matching pieces can only be found in the cases of conspicuous, unique and easily-distinguishable smoothed-in, glazed or ornamented vessels.

${ }^{16}$ From the same location comes a storage jar with yellowish-white slip (2013.14.4.17.), the other fragment of which comes from the debris above the courtyard's clayey, mortary layer (2013.14.3.8.). These three layers were excavated in different years

Acta Archaeologica Academiae Scientiarum Hungaricae 71, 2020
}

(1994 and 1999). In the absence, however, of data on depth, I cannot determine the connection between these layers.

${ }^{17}$ Smoothed-in jug: 2013.13.2.11-12. room IIb/N upper debris +2013.13 .6 .238 room $\mathrm{IIb} / \mathrm{N}$ greyish-brown infill above mortary floor +2013.13 .9 .2 . room IIb/N below the mortary floor +2013.13 .11 .27 . room $\mathrm{Ilb} / \mathrm{N}$ below the mortary clay debris +2013.13 .16 .91 . (2 pieces) mud-brick section wall, room $\mathrm{I} / \mathrm{W}$ above the layer $80 \mathrm{~cm}$ from the northern wall top + 2013.14.23.1. room III/N (bag without label).

${ }^{18}$ Smoothed-in pot rim fragment (OTTOMÁNYI 2012, 377, Fig. 12.10, Fig. 15.2, zs/32. + zs/53.).

${ }^{19}$ In room $\mathrm{IIb} / \mathrm{N}$, after all, there are matching fragments from the layer both below and above mortary floor. 
Table 1.

The pottery of Room III North by layers

\begin{tabular}{|c|c|c|c|c|c|c|c|c|c|c|}
\hline Cat. no. & $\begin{array}{l}\text { Layer } \\
\text { (Room } \\
\text { III/N) }\end{array}$ & $\begin{array}{l}\text { Glazed } \\
(115 \text { pcs })\end{array}$ & $\begin{array}{l}\text { Smoothed-in } \\
(19 \text { pcs })\end{array}$ & $\begin{array}{l}\text { Smoothed } \\
(124 \mathrm{pcs})\end{array}$ & $\begin{array}{l}\text { Household } \\
\text { pottery } \\
\text { (gritty, hard) } \\
(552 \text { pcs) }\end{array}$ & $\begin{array}{l}\text { Household } \\
\text { pottery } \\
\text { (well- } \\
\text { levigated) } \\
\text { (178 pcs) }\end{array}$ & $\begin{array}{l}\text { HM } \\
(52 \text { pcs }), \\
\text { SW } \\
(8 \text { pcs })^{20}\end{array}$ & Other & Period & $\begin{array}{l}\text { Pottery } \\
\text { group }^{21}\end{array}$ \\
\hline $\begin{array}{l}2013.14 .1 . \\
(+2013.13 .23 .)\end{array}$ & $\begin{array}{l}\text { Area between } \\
\text { r. II/N and } \\
\text { I/W, upper } \\
\text { stony brown, } \\
1994 \text {. } \\
\text { (+ IIb/N infill } \\
\text { above yel- } \\
\text { low, clayey } \\
\text { floor, 1996) }\end{array}$ & $\begin{array}{l}21 \text { ( } 5 \text { mor- } \\
\text { taria, } 11 \text { jugs, } \\
5 \text { other } \\
\text { bowls; } 6 \text { late } \\
\text { white) } \\
\text { Fig. } 5.5 \text {; } \\
\text { Fig. 10.2-3 }\end{array}$ & $\begin{array}{l}6 \text { ( } 1 \text { bowl, } \\
4 \text { jugs, } 1 \text { frag- } \\
\text { ment, } 2 \text { lattice, } \\
3 \text { vertical, } \\
\text { Fig. } 7.3 \text {; } \\
\text { Fig. } 8.4\end{array}$ & \begin{tabular}{|l|}
17 \\
$($ Fig. $7.4-5 ;$ \\
$\mathbf{1}$ black, \\
shiny)
\end{tabular} & $\begin{array}{l}55 \text { ( } 21 \text { pcs } \\
\text { late: } \\
10 \text { white, } \\
10 \text { ribbed, } \\
1 \text { wavy line } \\
\text { on horizontal } \\
\text { bowl rim, } \\
1 \text { impression } \\
\text { on jug shoul- } \\
\text { der })^{22} \text {. } \\
\text { Fig. } 11.2\end{array}$ & 17 & 4 & $\begin{array}{l}\text { African red } \\
\text { slip ware } \\
\text { rim }\end{array}$ & 4 & $\begin{array}{l}\text { III } \\
(28 \%)\end{array}$ \\
\hline $\begin{array}{l}2013.14 .2 .+ \\
14.3 .+14.4 .+ \\
14.21\end{array}$ & $\begin{array}{l}\text { Surface be- } \\
\text { tween r. } \\
\text { IIb/N and } \\
\text { I/W, upper } \\
\text { yellowish- } \\
\text { brown layer } \\
\text { (1994) + } \\
\text { above clayey, } \\
\text { mortary layer } \\
\text { (1999) + } \\
\text { above clayey } \\
\text { brown layer } \\
(1994)+\mathrm{r} \text {. } \\
\text { III/N NE cor- } \\
\text { ner, removal } \\
\text { of daub } \\
\text { debris } 30-40 \\
\text { cm from the } \\
\text { wall (1993) }\end{array}$ & $\begin{array}{l}20 \text { (10 mor- } \\
\text { taria, } 1 \text { bowl } \\
\text { with inverted } \\
\text { rim, } 1 \text { bowl } \\
\text { with horizon- } \\
\text { tal rim, } \\
1 \text { bowl with } \\
\text { glaze spot, } \\
7 \text { jugs } \\
\text { ( } 2 \text { late, } \\
\text { white) } \\
\text { Fig. } 4.2\end{array}$ & 1 jug (vertical) & $\begin{array}{l}51 \text { (1 bi- } \\
\text { conical } \\
\text { bowl: } \\
\text { Fig. } 7.7)\end{array}$ & $\begin{array}{l}59 \text { ( } 2 \text { late: } \\
1 \text { ribbed, } \\
1 \text { white; } \\
2 \text { densely } \\
\text { incised, } \\
1 \text { broom- } \\
\text { stroked) } \\
\text { Fig. 12.6; } \\
\text { Fig. } 14.4\end{array}$ & $\begin{array}{l}45 \text { ( } 5 \text { me- } \\
\text { dium-hard) }\end{array}$ & $\begin{array}{l}20+ \\
2 \mathrm{SW} \\
(\text { Fig. 16.2) }\end{array}$ & & 4 & $\begin{array}{l}\text { III } \\
(3 \%)\end{array}$ \\
\hline $\begin{array}{l}2013.14 .5 .+ \\
14.9 .\end{array}$ & $\begin{array}{l}\text { South of r. } \\
\text { II/N, room } \\
\text { with stone } \\
\text { mortar, dark } \\
\text { brown above } \\
\text { clay surface } \\
(1994)+\text { r. } \\
\text { III/N (1994) }\end{array}$ & $\begin{array}{l}3 \text { (morta- } \\
\text { rium, other } \\
\text { bowl, jug) }\end{array}$ & $\begin{array}{l}1 \text { (diagonal } \\
\text { lines) }\end{array}$ & $\begin{array}{l}10 \\
\text { (1 shiny, } \\
\text { black; } \\
\text { Fig. 7.1) }\end{array}$ & $\begin{array}{l}38 \text { ( } 22 \text { late: } \\
9 \text { white, } \\
1 \text { bowl with } \\
\text { horizontal } \\
\text { rim, } 1 \text { Leány- } \\
\text { falu, } 13 \text { trace } \\
\text { of wheel); } \\
\text { Fig. } 12.2\end{array}$ & 8 (Fig. 14.6) & 6 & & 4 & $\begin{array}{l}\text { IIIa } \\
(36.4 \%)\end{array}$ \\
\hline
\end{tabular}

${ }^{20} \mathrm{HM}=$ Hand-made $: 52$ pieces, one of which is smoothed $\mathrm{SW}=$ Slow-wheel: 8 pieces, of which two are smoothed. Since the 3 smoothed pieces already appear among the smoothed vessels, I only included 57 items in the total for hand-made and slow-wheel-made vessels.

${ }^{21} \mathrm{I}$ included here, in parentheses, the ratio (in percentage) within the layers' pottery of new-type vessels which appeared at the turn of the 4 th and $5^{\text {th }}$ centuries. In the table, written in bold, are the latest materials.
${ }^{22}$ Of the 10 white fragments, two are ribbed. One jug has impressed motifs. The other 8 ribbed motifs are on grey wall fragments.

${ }^{23}$ 2013.14.2.-4. Based on the sketch on the bag: not room III/N, but the western part of the courtyard. In 1994 the excavators had not designated room III/N yet, so the label is unclear. But this was also the location of the exterior furnace heating the room. Since it was left out of the paper presenting the courtyard's material, I am publishing it here, especially since one of the vessels matches the material from room III/N (Fig. 5.1). 


\begin{tabular}{|c|c|c|c|c|c|c|c|c|c|c|}
\hline Cat. no. & $\begin{array}{l}\text { Layer } \\
\text { (Room } \\
\text { III/N) }\end{array}$ & $\begin{array}{l}\text { Glazed } \\
(115 \text { pcs })\end{array}$ & $\begin{array}{l}\text { Smoothed-in } \\
(19 \text { pcs })\end{array}$ & $\begin{array}{l}\text { Smoothed } \\
(124 \mathrm{pcs})\end{array}$ & $\begin{array}{l}\text { Household } \\
\text { pottery } \\
\text { (gritty, hard) } \\
(552 \text { pcs) }\end{array}$ & $\begin{array}{l}\text { Household } \\
\text { pottery } \\
\text { (well- } \\
\text { levigated) } \\
(178 \mathrm{pcs}) \\
\end{array}$ & $\begin{array}{l}\text { HM } \\
(52 \text { pcs }), \\
\mathbf{S W} \\
(8 \text { pcs })^{20}\end{array}$ & Other & Period & $\begin{array}{l}\text { Pottery } \\
\text { group }^{21}\end{array}$ \\
\hline $\begin{array}{l}2013.14 .6 . \\
(+2013.12 .1 \\
+2013.11 .6 .)\end{array}$ & $\begin{array}{l}\text { III/N upper } \\
\text { daub layer: } \\
\mathrm{N} \text { gate, } \\
\text { southern } \\
\text { foreground } \\
\text { of II/N, } 1994 \\
(+\mathrm{r} . \mathrm{II} / \mathrm{N} \\
20-40 \mathrm{~cm} \\
(1994)+\mathrm{r} \text {. } \\
\mathrm{I} / \mathrm{N} \text { upper } \\
\text { daub debris } \\
\text { 1994) }\end{array}$ & $\begin{array}{l}18 \text { ( } 1 \text { bowl } \\
\text { with inverted } \\
\text { rim, } 3 \text { bowls } \\
\text { with horizon- } \\
\text { tal rim, } \\
4 \text { other } \\
\text { bowls, } \\
2 \text { mortaria, } \\
4 \text { jugs, } \\
4 \text { mugs; } \\
7 \text { late; }{ }^{24} \\
\text { Fig. } 4.1,4-6 \text {, } \\
\text { Fig. 5.3,7, } \\
\text { Fig. 6.2) }\end{array}$ & $\begin{array}{l}2 \text { biconical } \\
\text { bowls (verti- } \\
\text { cal; wave, in } \\
\text { bands; } \\
\text { Fig. } 7.8-9 \text {, } \\
\text { Fig. 10.5) }\end{array}$ & $\begin{array}{l}10 \\
(\text { Fig. 9.1) }\end{array}$ & $\begin{array}{l}134 \text { (89 late: } \\
55 \text { white, } \\
\text { 16 Leány- } \\
\text { falu, } 39 \text { trace } \\
\text { of wheel, } \\
11 \text { incisions, } \\
1 \text { broom- } \\
\text { stroked); } \\
\text { Fig. 11.3,5; } \\
\text { Fig. 12.5,7; } \\
\text { Fig. 13.1-4; } \\
\text { Fig. 15.2,6 }\end{array}$ & $\begin{array}{l}14 \text { (3 me- } \\
\text { dium-hard, } \\
\text { Fig. 6.4) }\end{array}$ & $\begin{array}{l}1 \\
(\text { Fig. 16.1) }\end{array}$ & $\begin{array}{l}1 \text { painted, } \\
\text { spindle } \\
\text { whorls } \\
\text { (Fig. 12.9- } \\
11 \text { ) }\end{array}$ & 4 & $\begin{array}{l}\text { III } \\
(55 \%)\end{array}$ \\
\hline 2013.14 .7 & $\begin{array}{l}\text { By the N } \\
\text { gate, fore- } \\
\text { ground of } \\
\text { II/N (r. III/N) } \\
\text { from the in- } \\
\text { fill of the } \\
\text { flue. } 1994 .+ \\
\text { same location } \\
-40 \mathrm{~cm} \text {, } \\
1995 .\end{array}$ & $\begin{array}{l}2 \text { (mortar- } \\
\text { ium, intact } \\
\text { jug: Fig. 6.1; } \\
\text { Fig. 10.1) }\end{array}$ & & & $\begin{array}{l}7 \text { ( } 7 \text { late: } \\
5 \text { white, } \\
5 \text { Leányfalu } \\
\text { (ribbed), } \\
1 \text { wavy line, } \\
1 \text { dense lines) }\end{array}$ & 1 (Fig. 14.5) & 1 & & 3 & $\begin{array}{l}\mathrm{IIb} / \mathrm{IIIb} \\
(63.6 \%)\end{array}$ \\
\hline 2013.14 .12$. & $\begin{array}{l}\text { Western half } \\
\text { of room } \\
\text { III/N, exca- } \\
\text { vation of the } \\
\text { floor. (In } \\
1996 \text { the } \\
\text { upper floor } \\
\text { with the } \\
\text { stone mortar } \\
\text { was exca- } \\
\text { vated) }\end{array}$ & $\begin{array}{l}9 \text { (4 mortaria, } \\
2 \text { bowls with } \\
\text { a horizontal } \\
\text { rim (of these } \\
\text { one with } \\
\text { wavy line), } \\
2 \text { other } \\
\text { bowls, } 1 \text { jug) }\end{array}$ & $\begin{array}{l}1 \text { jug (with } \\
\text { diagonal lines; } \\
\text { Fig. 8.2) }\end{array}$ & 9 & $\begin{array}{l}8 \text { (1 trace } \\
\text { of wheel- } \\
\text { ing, } 1 \text { in- } \\
\text { cised })\end{array}$ & $\begin{array}{l}24 \text { ( } 3 \text { me- } \\
\text { dium-hard), } \\
1 \text { rim of } \\
\text { waster } \\
\text { (Fig. 14.3) }\end{array}$ & 4 & $\begin{array}{l}2 \text { neutral- } \\
\text { coloured }\end{array}$ & 3 & IIa (2\%) \\
\hline 2013.14 .13$. & $\begin{array}{l}\text { Western half } \\
\text { of III/N, re- } \\
\text { moval of the } \\
\text { stone debris, } \\
1996\end{array}$ & $\begin{array}{l}3 \text { (1 bowl } \\
\text { with horizon- } \\
\text { tal rim, } \\
1 \text { other bowl, } \\
1 \text { jug) }\end{array}$ & $\begin{array}{l}3 \text { (2 jugs, } \\
1 \text { bowl; } \\
2 \text { vertical, } \\
1 \text { Murga; } \\
\text { Fig. 9.2-3) }\end{array}$ & 6 & 1 & $\begin{array}{l}6 \text { (1 me- } \\
\text { dium-hard, } \\
1 \text { with } \\
\text { pinches; } \\
\text { Fig. 12.8) }\end{array}$ & 2 & $\begin{array}{l}6 \text { early } \\
\text { (painted, } \\
\text { neutral- } \\
\text { coloured } \\
\text { lamps) }\end{array}$ & 4 & $\begin{array}{l}\text { IIa } \\
(11 \%)\end{array}$ \\
\hline 2013.14.14. & $\begin{array}{l}\text { Northern half } \\
\text { of Room } \\
\text { III/N, upper } \\
\text { debris, } 1996\end{array}$ & 2 mortaria & & 1 & 5 & $\begin{array}{l}4 \text { (1 me- } \\
\text { dium-hard) }\end{array}$ & & & 4 & $\mathrm{Ib}$ \\
\hline
\end{tabular}

${ }^{24} 3$ yellowish-white, 2 with impressions/notches (one with dented wall), 2 gritty Leányfalu types. There was a lump of green glaze on the burnt foot of one of the jugs.

Acta Archaeologica Academiae Scientiarum Hungaricae 71, 2020 


\begin{tabular}{|c|c|c|c|c|c|c|c|c|c|c|}
\hline Cat. no. & $\begin{array}{l}\text { Layer } \\
\text { (Room } \\
\text { III/N) }\end{array}$ & $\begin{array}{l}\text { Glazed } \\
(115 \text { pcs })\end{array}$ & $\begin{array}{l}\text { Smoothed-in } \\
(19 \text { pcs })\end{array}$ & $\begin{array}{l}\text { Smoothed } \\
(124 \mathrm{pcs})\end{array}$ & $\begin{array}{l}\text { Household } \\
\text { pottery } \\
\text { (gritty, hard) } \\
(552 \text { pcs) }\end{array}$ & $\begin{array}{l}\text { Household } \\
\text { pottery } \\
\text { (well- } \\
\text { levigated) } \\
\text { (178 pcs) }\end{array}$ & $\begin{array}{l}\text { HM } \\
(52 \text { pcs }), \\
\text { SW } \\
(8 \mathrm{pcs})^{20}\end{array}$ & Other & Period & $\begin{array}{l}\text { Pottery } \\
\text { group }^{21}\end{array}$ \\
\hline 2013.14.15. & $\begin{array}{l}\text { By the east- } \\
\text { ern wall of } \\
\text { Room III/N, } \\
\text { above the } \\
\text { mortary } \\
\text { layer, (1995) }\end{array}$ & $\begin{array}{l}10 \text { ( } 2 \text { bowls } \\
\text { with inverted } \\
\text { rim, } 1 \text { with } \\
\text { segmented } \\
\text { rim, } 1 \text { other } \\
\text { bowl, } 6 \text { jugs; } \\
\mathbf{1} \text { trace of } \\
\text { wheeling) } \\
\text { Fig. } 4.3\end{array}$ & & $\begin{array}{l}1 \text { shiny, } \\
\text { black }\end{array}$ & 11 & 2 & $1+2 S W$ & & $3-4$ & $\begin{array}{l}\text { IIc } \\
(7.4 \%)\end{array}$ \\
\hline 2013.14 .16$. & $\begin{array}{l}\text { Room III/N, } \\
\text { corner by the } \\
\text { western half, } \\
1996\end{array}$ & & & & 4 & $\begin{array}{l}5 \text { (1 Leány- } \\
\text { falu pot, } \\
3 \text { medium- } \\
\text { hard; } \\
\text { Fig. 15.1.) }\end{array}$ & 1 & $\begin{array}{l}9 \text { early } \\
\text { (painted, } \\
\text { brick- } \\
\text { coloured), } \\
\text { spindle } \\
\text { whorls }\end{array}$ & $?$ & $\mathrm{Ia}$ \\
\hline 2013.14 .17$. & $\begin{array}{l}\text { Western half } \\
\text { of r. III/N, } \\
\text { layer with } \\
\text { stone mortar, } \\
1996\end{array}$ & $\begin{array}{l}4 \text { (1 bowl, } \\
3 \text { jugs) }\end{array}$ & $\begin{array}{l}1 \text { bowl (lattice } \\
\text { and diagonal } \\
\text { band; Fig. } 8.3 \text { ) }\end{array}$ & 3 & 6 & $\begin{array}{l}2 \text { (1 me- } \\
\text { dium-hard) }\end{array}$ & 1 & $\begin{array}{l}1 \text { painted, } \\
2 \text { whet- } \\
\text { stones }\end{array}$ & 3 & $\begin{array}{l}\text { IIa } \\
(5.5 \%)\end{array}$ \\
\hline 2013.14 .18$. & $\begin{array}{l}\text { Room III/N, } \\
\text { stone debris } \\
\text { by the south } \\
\text { wall of the } \\
\text { room with } \\
\text { stone mortar, } \\
\text { south of the } \\
\text { gate } 1994\end{array}$ & 1 jug & & 2 & & 2 & & & 4 & $\mathrm{Ib}$ \\
\hline 2013.14.19. & $\begin{array}{l}\text { Gate, south } \\
\text { of room II/N. } \\
\text { Room with } \\
\text { stone mortar, } \\
\text { southern side } \\
\text { of heating } \\
\text { flue, daub } \\
\text { debris above } \\
\text { lower clay, } \\
1994\end{array}$ & $\begin{array}{l}2 \text { (mortar- } \\
\text { ium, jug; } \\
\text { Fig. 5.4) }\end{array}$ & & $\begin{array}{l}7 \text { (1 bi- } \\
\text { conical } \\
\text { bowl, } \\
\mathbf{1} \text { Leány- } \\
\text { falu rim: } \\
\text { Fig. 7.2; } \\
\text { Fig. 11.1) }\end{array}$ & $\begin{array}{l}12 \text { ( } 2 \text { trace } \\
\text { of wheel- } \\
\text { ing) }\end{array}$ & 6 & $2+2 \mathrm{SW}$ & 1 painted & $2-3$ & $\begin{array}{l}\text { IIa } \\
(12.5 \%)\end{array}$ \\
\hline 2013.14 .20 . & $\begin{array}{l}\text { South of the } \\
\text { gateway, } \\
\text { from daub, } \\
1993\end{array}$ & $\begin{array}{l}11 \text { ( } 2 \text { mor- } \\
\text { taria, } 1 \text { bowl } \\
\text { with horizon- } \\
\text { tal rim, } 1 \\
\text { other bowl, } \\
1 \text { mug, } 5 \\
\text { jugs/mugs, } \\
1 \text { handle with } \\
\text { glaze spot, } \\
1 \text { mug; } \\
6 \text { late; }{ }^{25} \\
\text { Fig. } 4.8 ; \\
\text { Fig. 5.6) }\end{array}$ & $\begin{array}{l}1 \text { pitcher } \\
\text { (Murga, lat- } \\
\text { tice, vertical, } \\
\text { trace of } \\
\text { wheeling: } \\
\text { Fig. 9.4) }\end{array}$ & 3 & $\begin{array}{l}83 \text { ( } 74 \text { late: } \\
12 \text { Leányfalu } \\
\text { type, } 37 \text { trace } \\
\text { of wheeling, } \\
5 \text { wavy line, } \\
1 \text { broom- } \\
\text { stroked; } \\
\text { Fig. } 12.3 \text {; } \\
\text { Fig. 15.3) }\end{array}$ & $\begin{array}{l}17 \text { (8 me- } \\
\text { dium-hard; } \\
\text { Fig. 14.1) }\end{array}$ & $6 \mathrm{pcs}$ & & 4 & $\begin{array}{l}\text { III } \\
(67.5 \%)\end{array}$ \\
\hline
\end{tabular}

${ }^{25} 5$ white (with trace of wheel-throwing on one of them) and one bowl with gritty fabric and wavy rim. 


\begin{tabular}{|c|c|c|c|c|c|c|c|c|c|c|}
\hline Cat. no. & $\begin{array}{l}\text { Layer } \\
\text { (Room } \\
\text { III/N) }\end{array}$ & $\begin{array}{l}\text { Glazed } \\
(115 \text { pcs })\end{array}$ & $\begin{array}{l}\text { Smoothed-in } \\
(19 \mathrm{pcs})\end{array}$ & $\begin{array}{l}\text { Smoothed } \\
(124 \mathrm{pcs})\end{array}$ & $\begin{array}{l}\text { Household } \\
\text { pottery } \\
\text { (gritty, hard) } \\
(552 \text { pcs) }\end{array}$ & \begin{tabular}{|l|} 
Household \\
pottery \\
(well- \\
levigated) \\
$(178 \mathrm{pcs})$ \\
\end{tabular} & $\begin{array}{l}\text { HM } \\
(52 \text { pcs }), \\
\text { SW } \\
(8 \text { pcs })^{20}\end{array}$ & Other & Period & $\begin{array}{l}\text { Pottery } \\
\text { group }^{21}\end{array}$ \\
\hline 2013.14 .22$. & $\begin{array}{l}\text { W fore- } \\
\text { ground of N } \\
\text { gate, lower } \\
\text { debris, }- \\
120-130 \mathrm{~cm}, \\
1994\end{array}$ & 1 mortarium & $\begin{array}{l}1 \text { jug (lattice, } \\
\text { ribbed: } \\
\text { Fig. } 6.3 \text {; } \\
\text { Fig. 10.4) }\end{array}$ & $2 \mathrm{pcs}$ & $\begin{array}{l}28 \text { (20 late: } \\
5 \text { Leányfalu, } \\
10 \text { trace of } \\
\text { wheeling, } \\
14 \text { yellowish- } \\
\text { red; } \\
\text { Fig. 15.4-5) }\end{array}$ & 1 & & $\begin{array}{l}1 \text { painted, } \\
\text { whetstone }\end{array}$ & $2-3$ & $\begin{array}{l}\text { III } \\
(62 \%)\end{array}$ \\
\hline $\begin{array}{l}2013.14 .23 \\
(+2013.13 .2 \\
+6 .+9 .+11 \\
+16 .)\end{array}$ & $\begin{array}{l}\text { R. III/N } \\
\text { without } \\
\text { label }^{26} \\
\text { (+ room } \\
\text { IIb/N upper } \\
\text { debris, and } \\
\text { greyish- } \\
\text { brown infill } \\
\text { above mor- } \\
\text { tary floor + r. } \\
\text { IIb/N under } \\
\text { mortary } \\
\text { floor, etc.) }\end{array}$ & & $\begin{array}{l}1 \text { jug (vertical } \\
\text { and wave, } \\
\text { shiny black: } \\
\text { Fig. } 8.1 \text {; } \\
\text { Fig. 10.6) }\end{array}$ & & & & & $\begin{array}{l}\text { glass jug } \\
\text { foot }\end{array}$ & 4 & III \\
\hline 2018.1.19.1. & $\begin{array}{l}\text { Next to grave } \\
\text { no. } 94 / 1 \mathrm{dug} \\
\text { in room III/N } \\
(1998)^{27}\end{array}$ & & & & & & $\begin{array}{l}1 \text { large pot } \\
(\text { Fig. 16.3) }\end{array}$ & & 4 & \\
\hline$?$ & $\begin{array}{l}\text { R. III/N. } \\
\text { From the } \\
\text { floor in the } \\
\text { room built } \\
\text { west and } \\
\text { south of the } \\
\text { gateway }^{28}\end{array}$ & & & & $\begin{array}{l}\text { intact mug } \\
\text { (white, } \\
\text { trace of } \\
\text { wheeling: } \\
\text { Fig. 11.6; } \\
\text { Fig. 13.5) }\end{array}$ & & & & $?$ & $\begin{array}{l}\text { IIIc } \\
?\end{array}$ \\
\hline 2018.1 .13 & $\begin{array}{l}\text { Daub close to } \\
\text { gateway, } \\
1998\end{array}$ & $\begin{array}{l}7 \text { (1 mortar- } \\
\text { ium, } 1 \text { bowl } \\
\text { with horizon- } \\
\text { tal rim, } 4 \text { jug/ } \\
\text { pot wall; } \\
6 \text { white; } \\
\text { Fig. } 4.7)\end{array}$ & $\begin{array}{l}1 \text { jug (lattice, } \\
\text { vertical: } \\
\text { Fig. 9. 5) }\end{array}$ & $\begin{array}{l}5 \text { pcs } \\
\text { (1 black; } \\
\text { Fig. 7.6) }\end{array}$ & $\begin{array}{l}98 \text { (72 late: } \\
2 \text { gravelly, } 1 \\
\text { perhaps SW; } \\
43 \text { trace of } \\
\text { wheeling, } \\
\text { many whit- } \\
\text { ish-grey); } \\
\text { Fig. 11.4; } \\
\text { Fig. 12.4) }\end{array}$ & $\begin{array}{l}20 \text { (2 me- } \\
\text { dium-hard); } \\
\text { Fig. } 14.2 \\
\text { (glaze spot) }\end{array}$ & 4 & 4 & 4 & $\begin{array}{l}\text { III } \\
(61 \%)\end{array}$ \\
\hline 2018.1.15. & $\begin{array}{l}\text { South of the } \\
\text { entrance to } \\
\text { N. wing, } \\
\text { from the sur- } \\
\text { face of the } \\
\text { debris, } 1993\end{array}$ & 1 (bowl foot) & & & $\begin{array}{l}3 \text { (3 late: } 2 \\
\text { yellowish- } \\
\text { white, one of } \\
\text { which } \\
\text { densely in- } \\
\text { cised) }\end{array}$ & $\begin{array}{l}2 \text { (1 not } \\
\text { hard) }\end{array}$ & & 1 & 4 & $\begin{array}{l}\mathrm{IIb} / \mathrm{IIIb} \\
(43 \%)\end{array}$ \\
\hline
\end{tabular}

${ }^{26}$ Two beautiful fragments were removed (smoothed-in vessel and glass foot), but there is no label on the bag.

${ }^{27}$ Only one large, hand-made vessel was removed from here. I have not seen the other material yet.
${ }^{28}$ The label on the vessel's box is no longer visible. Based on the diary, an intact vessel was found here in 1993. Other pieces of pottery have not been recorded from here. 


\section{POTTERY FORMS}

Only one imported vessel, an African red slip bowl rim, was found in the upper stony-brown infill (2013.14.1.34.). It is from a Hayes form $61 \mathrm{~b}$ bowl, which is one of the latest types in Pannonia (second half of $4^{\text {th }}$ century-first half of $5^{\text {th }}$ century).$^{29}$ The same form is attested in the upper, stony debris of room I/W. ${ }^{30}$

In Pannonia, in the $4^{\text {th }}$ century, they tried substitute the progressively decreasing number of imported vessels using local materials. Metal, glass and terra sigillata imitations were made using new techniques and ornaments. New techniques included the glazing or burnishing of the vessels' surface. The latest variants were decorated with incised and smoothed-in motifs. Many small workshops produced locally common everyday household pottery used for cooking and baking, on which, too, the incised and notched ornaments appear from the end of the century. It is characteristic of the period's pottery that the same bowl and jug types are often used on grey household, glazed or smoothed variants. Painting, still common in the $3^{\text {rd }}$ century, all but disappears in the $4^{\text {th }}$ century. Alongside wheelthrown pottery, from the second half of the $4^{\text {th }}$ century, the importance of hand-made and slow-wheel-made vessels gradually increases.

The composition of pottery in room III/N is similar to other parts of the fort (Fig. 3.1). Most are household pottery (70\%). The dominant group within these are the vessels with a gritty, hard-fired fabric (53\%). The quantity of glazed vessels $(11 \%)$ and pottery with smoothed surfaces (11.9\%) is almost the same. Hand-made and slowwheel-made ceramics make up $5.7 \%$. Least frequent are the smoothed-in ornaments $(1.8 \%){ }^{31}$

\subsection{Glazed pottery}

Glazed pottery appears in nearly every layer; altogether: 115 pieces. ${ }^{32}$ From the fort's construction until its destruction, its inhabitants used glazed vessels. We can make chronological observations based on their designs and ornaments. They were mostly produced in the usual, $4^{\text {th }}$ century way: well-levigated, fired medium-hard or hard. The latest vessels, characteristic of the first half of the $5^{\text {th }}$ century - yellowish-brown, gritty fabric, with surfaces sometimes decorated with impressed ornaments or traces of wheel - only appear in the topmost, yellowish-brown, stony and daub debris. There are altogether 28 such late fragments $(24.3 \%) .{ }^{33}$ Their form, too, differs from earlier types (Fig. 3.3): bowls with a horizontal rim and shoulder carination (impression, incision), jugs with one handle (dents, notches), a jug with a collared rim, and so-called Leányfalu-type mug/pot (with trace of wheel). On their surface only a very thin, light-coloured or burnt layer of glaze can be found.

\subsubsection{The colour of the glaze and the fabric}

The colour of the glaze: Most common are green (28 pieces, $24.3 \%)$, dark green (21 pieces, $18.3 \%)$, and greenish-brown (16 pieces, 14\%) glaze. There is an equal number of pieces with light green and yellowish-brown glaze (13 pieces each, i.e. 11.3\%). Of the rest there are only a few pieces: yellowish-green 1 piece, dark brown 3 pieces. There are certain colours, of which the majority are shiny, like dark brown (two out of three shiny) and greenish-brown (10 out of 16 shiny). All three yellowish-brown vessels are shiny, that is not the case with the other colours. A vessel can have glazes of different colours if the contiguous, thick glaze on the inside of the vessel is darker, while the glaze spilled on the outside is lighter, e.g. yellowish-brown on the inside, greenish-yellow on the outside (see 2013.14.15.7.). We can see such lines, spots and glaze patches on the outside of bowls, or the foot or

\footnotetext{
${ }^{29}$ I would like to thank Dénes Gabler for identifying the fragment; a similarly late African red slip fragment came to light in Visegrád-Lepence (GABLER 2016, 141, Fig. 18).

${ }^{30}$ OtTomÁnYi 2012, table 1 . (zs/5.1). In room I/W 3 African red slip bowl fragments were found in the upper, stony debris layer (zs/5., 10., 11.): a Hayes form 50 rim and wall (Type D: AD $320-380$ ), as well as a Hayes form 61 b bowl rim and a small wall fragment.

${ }^{31}$ OtTomÁnYi 2015a, 16, Fig. 7-8 (distribution of pottery in the south and west wing); OTTOMÁNYI 2018a, Fig. 1 and 6 (court-
}

yard); OtTományi 2018b, 4 (NW tower); Otтományi 2018c, Fig. 2 (Room I/N).

${ }^{32}$ The one layer without glazed pottery: inner corner, room III/N, in front of its western half (2013.14.16.). Here there are relatively many early painted and neutral-coloured fragments.

${ }^{33}$ Of these 22 pieces are whitish-grey; their fabric is, in all cases, gritty, fired 'ringing' hard. The others are reddish-grey, their fabric was hard-fired, or gritty, hard-fired. Ribbing with traces of wheel appears on 3 vessels, of these only one is whitish-grey. Notches appear on 3 vessels and the same number has a wavy rim. 

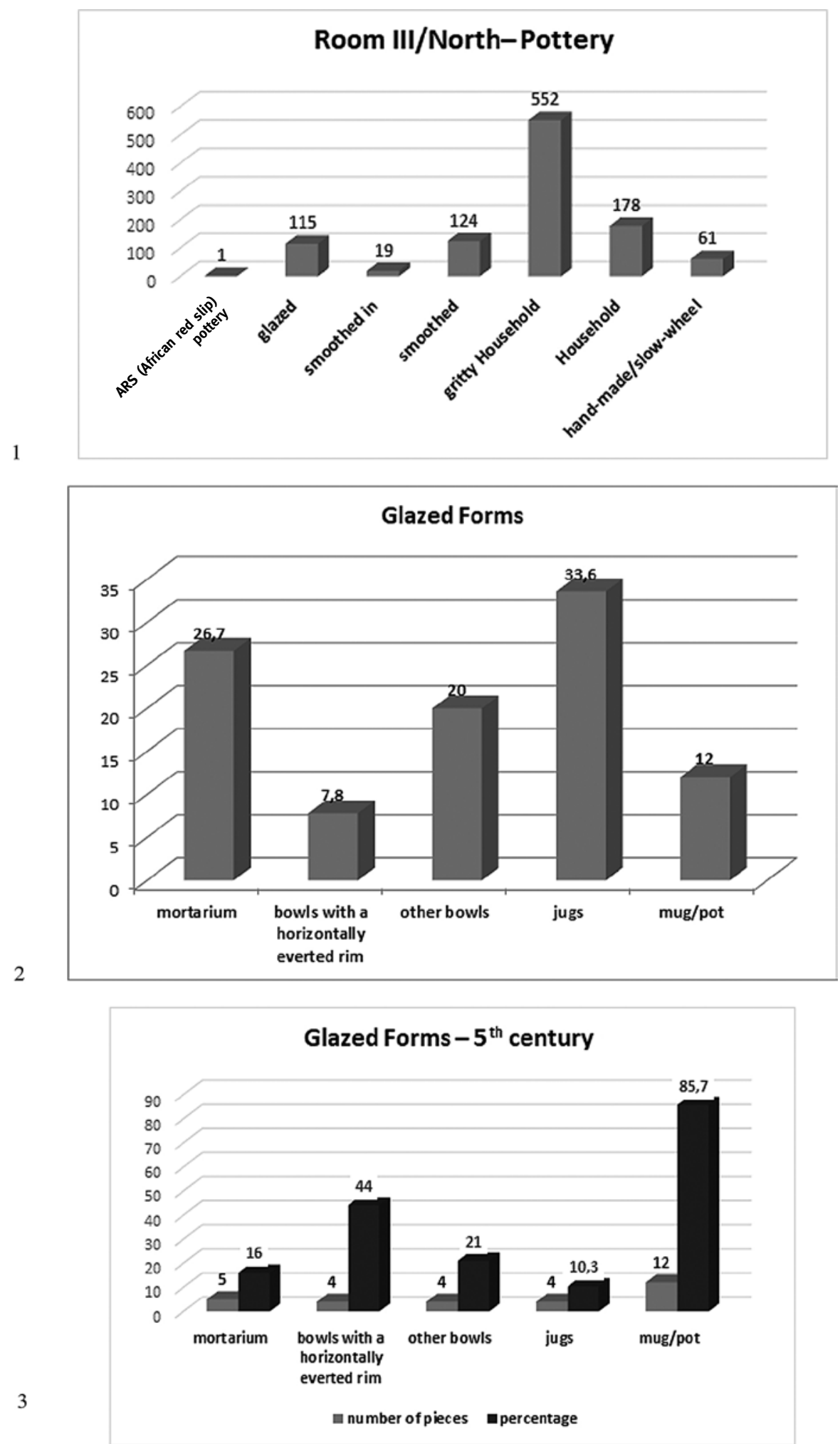

Fig. 3. 1: Pottery composition in room III/N (number of pieces); 2: Vessel forms of glazed pottery (percentage); 3 : The quantity of $5^{\text {th }}$ century vessels among glazed vessel forms 
lower part of jugs. On jugs, too, the glaze does not always cover the entire surface of the vessel. In the case of glaze spots it is possible that the vessel was not glazed, the glaze spot got on the vessel when household and glazed pottery were fired together (e.g. yellowish-brown glaze spot on white band handle: 2013.14.20.26.).

There is a very large amount of secondarily burnt glaze (39 pieces); of these the colour of 19 pieces cannot be determined. Sometimes the glaze was fired after the vessel broke (the fracture is also burnt), sometimes it is black only in places, but often the glaze on the whole surface was burnt pitted and blistered.

The fabric and colour of the vessels: Most glazed vessels are well-levigated, medium-hard fired. Later pieces are hard-fired (46 pieces, $40 \%$ ), half of which is gritty (23 pieces).

Reddish-grey is the most common colour (48 pieces). These include vessels fired in layers (red on the two edges, grey in the middle: 8 bowls, 3 jugs, 1 mug; or red on the outside, grey on the inside: 5 bowls, 1 jug). Often the whole vessel is grey, but on the outside (11 bowls), or inside ( 3 jugs), there is a thin red layer. The thin red layer can be under the glaze ( 2 jugs), but often precisely on the other side. And vice versa: the vessel is red, but there is a thin grey layer under the glaze ( 3 bowls, 3 jugs). The colour of the other vessels is red ( 25 pieces), grey (18 pieces), and two pieces are brownish-grey. The latest are the vessels, fired yellowish-white, of gritty fabrics (22 pieces), in the case of which either one side or the carination is grey (11 pieces), or, more rarely, pale red (4 pieces).

The relationship between glaze colour and vessel colour: yellowish-brown glaze always appears on red or reddish-grey fabrics and is connected with bowls. As glaze spot it can appear on the exterior of jugs and mugs. Light green glaze primarily appears on vessels made of fabrics fired yellowish-white (jugs, mugs) and on reddish-grey mortaria. Green glaze is the most common: it appears primarily on reddish-grey vessels, but also often on vessels made of yellowish-white and grey fabrics. Dark green glaze is typical for grey and reddish-grey jugs, less often for bowls. Greenish-brown glaze mostly appears on vessels made of reddish-grey and red fabrics, on all kinds of forms. Dark brown glaze in typical for red vessels. Burnt glaze can appear on vessels of any colour; most frequently on jugs and mugs fired yellowish-white (Table 2).

The fabric of the latest vessels is whitish-grey, whitish-red, the glaze on them is mostly burnt, light in colour, mostly light green (very thin, barely visible, sometimes only surviving in traces), see 2018.1.13.

The colour of the glaze depends on the workshop. After all, usually the basic glaze colours are produced by different kinds of firing. Oxidation firing produces yellow (yellowish-brown, yellowish-green), while reduction firing produces green (greenish-brown). This also impacts the colour of the fabric. The fabric of vessels with yellow, yellowish-brown glaze became red through oxidation firing, while the fabric of vessels with green, greenish-brown glaze, through reduction firing, is mostly grey. ${ }^{34}$ Often, underneath the glaze, a thin layer, fired a different colour, can be observed. Its colour, too, depends on the method of firing; e.g. on a vessel made of a grey fabric the thin layer under the glaze is red, while on a vessel made of a red fabric it is grey. ${ }^{35}$

Waster: The fragment with a melted, shiny green glaze lump stuck on the glazed foot, is perhaps a waster (2013.14.6.90.).

Table 2.

The relationship between the colours of the glaze and the fabric

\begin{tabular}{|l|l|l|l|l|l|l|l|}
\hline $\begin{array}{l}\text { colour of the } \\
\text { fabric }\end{array}$ & $\begin{array}{l}\text { yellowish- } \\
\text { brown glaze }\end{array}$ & $\begin{array}{l}\text { light green } \\
\text { glaze }\end{array}$ & green glaze & $\begin{array}{l}\text { dark green } \\
\text { glaze }\end{array}$ & $\begin{array}{l}\text { greenish- } \\
\text { brown glaze }\end{array}$ & brown glaze & burnt glaze \\
\hline grey & & 1 & 6 & 9 & 2 & & 3 \\
\hline reddish-grey & 3 & 5 & 14 & 12 & 10 & & 4 \\
\hline red & 8 & 1 & 4 & 1 & 5 & 2 & 4 \\
\hline yellowish-white & 1 & 6 & 6 & & & 1 & 8 \\
\hline
\end{tabular}

${ }^{34}$ OtTOMÁNYI 1991, 14-15; MikLÓsITY SZŐKe 2008, 172 (footnote 122 with further references).

\footnotetext{
${ }^{35}$ HoRVÁth 2011a, 606
} 


\subsubsection{Vessel forms}

Vessels with a glazed surface were primarily tableware (Fig. 3.2). Most are bowls (62 pieces) and jugs (39 pieces). Mugs are significantly fewer (14 pieces). ${ }^{36}$ At first they imitated sigillata, metal and glass vessels with the glazed surfaces. Later on glaze came to be applied on regular household pottery forms as well, especially if they were locally produced. ${ }^{37}$

Bowls (62 pieces)

Half of the bowls are mortaria (30 pieces). There are far fewer bowls with a horizontal rim (9 pieces), and with an inverted rim (4 pieces); there is also a bowl with a segmented rim and conical base as well as mug with a handle. In the absence of rims, the forms of foot or wall fragments with glaze on the inside remain unclear (17 pieces).

Mortarium: a vessel typical for Roman culinary culture. Its grit-roughened interior made it suitable for grinding spices and making sauces during the first three centuries of the Roman Period. In late Roman mortaria, the glaze was applied on top of the gritty surface; its function, therefore, must have changed partially. However, if we look at the quantity of mortaria among glazed vessels, which is always the highest on all Roman sites - be they military or civilian settlements - it is likely that mortaria continued to play a significant role in dining; perhaps no longer as kitchenware, but as serving vessels. ${ }^{38}$

Most mortaria are well-levigated, medium-hard fired and red, or reddish-brown (fired in layers), with greenish-brown or green glaze on the inside and rim. The rim of the earliest variant is painted, its glaze shiny yellowish-brown (2013.14.3.2.). If the fabric is grey, the glaze is green or dark green. The latest yellowish-white or yellowish-grey vessels were made with green glaze and of a hard-fired, rarely gritty, fabric (5 pieces: 2013.14.1.1. and 2. and 7., 2013.14.2.3., 2018.1.13.6.). ${ }^{39}$ All late pieces are from the upper stony and daub debris, but earlier types were also found along them.

Their collared rim can be segmented (Fig. 5.1), while by the late $4^{\text {th }}$ century the upright, shortening collar becomes progressively more prevalent (Fig. 5.2-4). ${ }^{40}$ Their wall - unlike the earlier, more spherical bowls - is steep and conical. Their mouth diameter varies between 13 and $25 \mathrm{~cm}$, most are larger bowls.

Bowls and cups with a horizontally everted rim: There are both smaller cups and larger bowls with such rims. They may have been part of a dinner set. The form is a traditional, $4^{\text {th }}$ century type (imitation of metal vessels and African red slip ware), which appears in the second half of the century with a glazed design. ${ }^{41}$ Its fabric is red, reddish-grey; its glaze green, greenish-brown. In room III/N there are five such fragments. On the rim of one there is an incised wavy line, which, for this type, is characteristic of the later vessels (2013.14.12.1.). Based on its fabric, however, it does not belong to the latest, $5^{\text {th }}$ century group. ${ }^{42}$ The exterior of a larger, flat bowl is smoothed (Fig. 4.4), with burnt greenish-brown glaze on the inside. ${ }^{43}$

${ }^{36}$ The rim did not survive in the case of every fragment; nor is the form always clear. In these cases fragments with glaze on the inside were classified as 'other bowl', while fragments with glaze on the outside were classified as 'jug', though the latter might also have belonged to mugs. Handles clearly belonged to jugs.

${ }^{37}$ Applying glaze to household pottery came to be practised in Pannonia from the Valentinian period or the last third of the $4^{\text {th }}$ century. See: Tokod (LÁNYI 1981, 73; BóNIS 1991, 135); ОTTOMÁNYI 1991, 20 (Leányfalu); MikLósity SzŐKE 2008, 170-171 (Brigetio).

${ }^{38}$ For references on the dating and spread of the vessel type see OTTOMÁNYi 2015a, footnote 154; CvJETIĆANIN 2006, 21-29, LRG 1-8 (late $3^{\text {rd }}$ century-early $5^{\text {th }}$ century); HoRVÁTH 2011a, 606-609, Fig. 5; BÓNIS 1991, 89, 123-129; At the Györ fort it is still attested in phase $1 \mathrm{~A}-\mathrm{B}$ of the Migration Period, during the early- $5^{\text {th }}$ century (TomkA 2004, Table 2.1, Table 3.2, Table 4.2).

${ }^{39}$ OTTOMÁNYI 2018a, 106 (courtyard) and there is a piece from the SW tower as well as room I/N (OTTOMÁNYi 2018c, 124).

${ }^{40}$ OtTományi 2015a, 27-28, Fig. 7.5 (segmented), Fig. 7.6, 8; OtтомÁNYi 2015b, 710; OtтOMÁNYi 2018a, Table 4. 6;
OtTOMÁnyi 1999, 338, Pl. II. 4-7; HoRVÁth 2011a, Fig. 4.1. and 5 (Keszthely-Fenékpuszta, segmented rim); GASSNER 2000, 219-221, Fig. 186; ŠvaŇA 2011, Fig. 3.1a-c (Iža: after Valentinian); CIGLENEČKI 1984, Fig. 3.38 (Tinje).

${ }^{41}$ Cup: CVJetićanin 2006, 34-39, LRG 27; HoRváth 2011a, 609-611, Fig. 4; GroH-SEDLMAYER 2002, Fig. 132/669 (Hayes form 52 imitation, Mautern, 350-400/500 CE); Bowl: CVJETIĆANIN 2006, 51-55, LRG 71; BóNIS 1991, 129-131, Fig. 9.1-7; The form is characteristic for periods 6-7 of the Mautern fort (GROH-SEDLMAYER 2002, 185-186, Fig. 132.802); it also lives on at highland sites in Slovenia during the $4^{\text {th }}-6^{\text {th }}$ centuries (CIGLENEČKI 1984, Fig. 3.32-34).

${ }^{42}$ Otтományi 1991, 16, Table 10. 52; Bónis 1991, Fig. 9.4; CiglenečKi 1984, Fig. 3.34-37 (Tinje: wavy line and impression on the rim of flat bowls. $4^{\text {th }}-6^{\text {th }}$ century).

${ }^{43}$ Similar flat bowls with a smoothed exterior at the west wing and the courtyard in front of it (OtтомÁNYI 2015a, 29, Fig. 11.5,7; OтTOMÁNYi 2018a, Table 4.1); Leányfalu: OtтомÁNYi 1991, Table 12.62. 


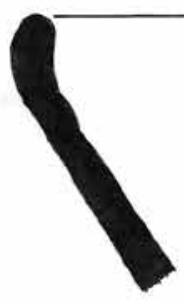

1

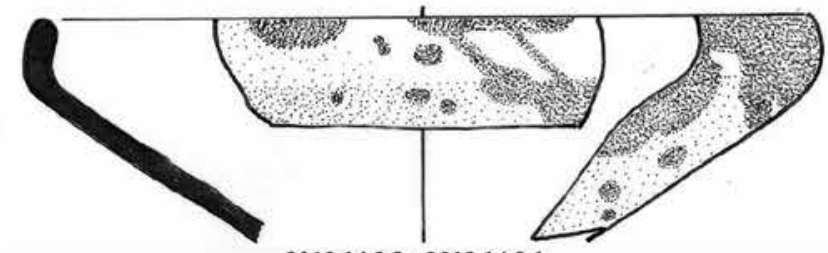

2013.14.2.2.+2013.14.3.1.

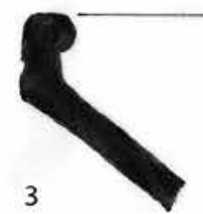

11<smiles>C#CC#C</smiles>

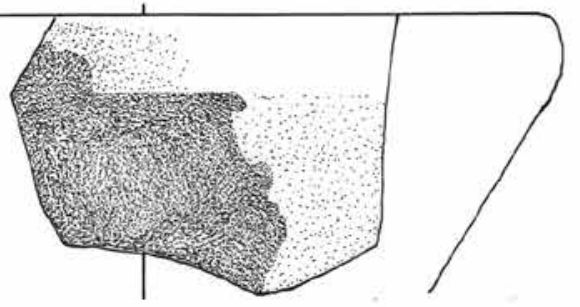

2013.14.6.85.

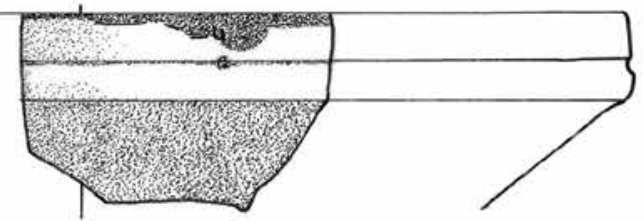

2013.14.15.1.
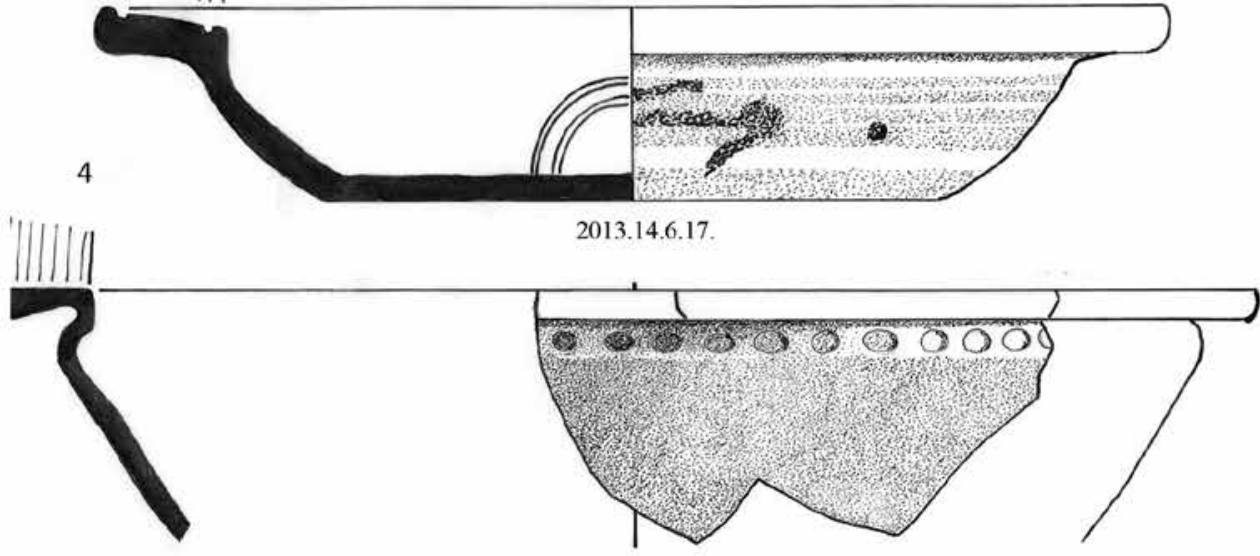

2013.14.6.87.

5

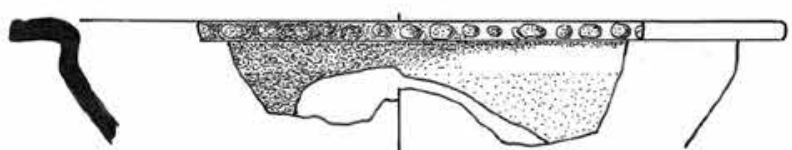

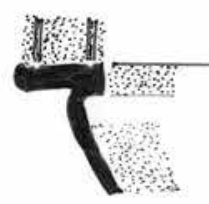

7

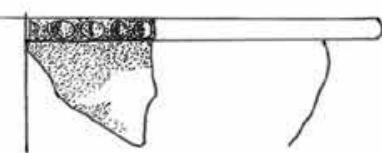

2018.1.13.1.

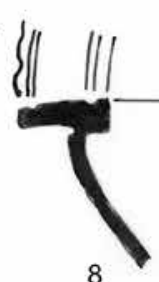

8
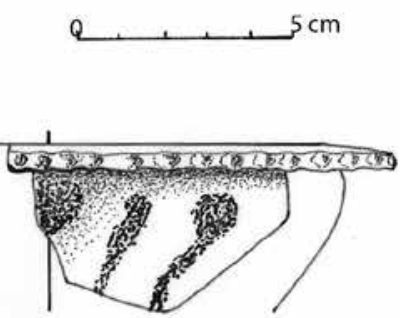

2013.14.20.1.

Fig. 4. Glazed bowls 
A later variant is the bowl, similar to the S-profile, with shoulder carination and a conical base. It is common not only in glazed but also in household pottery form from the last third of the $4^{\text {th }}$ century. There are impressions on its neck; its fabric is gritty, hard-fired (Fig. 4.5). ${ }^{44}$ The edge of three smaller cups, too, was made wavy with impressions (Fig. 4.6-8). ${ }^{45}$ Their fabric was hard-fired, gritty. Their colour is yellowish-white, and in one case red. They all have burnt glaze on the inside. These later items were found in the daub layer (2013.14.6., 14.20. and 2018.1.13.). In the same topmost daub layer there were also more traditional, earlier forms. These were also found during the excavation of the floor (2013.14.12.).

Bowl with an inverted rim (4 pieces; Fig. 4.1-2): traditional Roman bowl form (neutral-coloured, painted, grey variants), with the inside sometimes glazed in the $4^{\text {th }}$ century. ${ }^{46}$ Their fabric is red, reddish-grey, well-levigated, medium-hard fired. On the inside there is light-coloured glaze (greenish-brown, light green, yellowish-green) and in one case pitted burnt glaze. It was found in the upper destruction layer 3-4.

Bowl with segmented upper part and conical base (Fig. 4.3): This type can be connected with an early Roman form, which reappears with such a steep, conical lower part only in the last third of the $4^{\text {th }}$ century. It appears most frequently as smoothed or household pottery. In room III/ $\mathrm{N}$ it was found above the mortary layer, which can be connected with the destruction debris. Based on its shiny, brown glaze and design it cannot be placed in the latest group. It can also be found in other parts of the fort. ${ }^{47}$ The closest analogies are the bowls found at the Valentinian-period watchtowers at Pilismarót-Malompatak, Leányfalu and Budakalász-Luppacsárda. ${ }^{48}$

Cup with stabbed ornaments inkább stitched decoration (2013.14.1.10.; Fig. 10.2). A distinctive form, which already appears in the mid- $4^{\text {th }}$ century, is the cup with two-three handles, with a number of bands of stitched ornaments on its vertical upper part. ${ }^{49}$ The fragment of such a cup was found in the upper stony layer. Its fabric is hard-fired, yellowish-grey, its glaze light green. This type was still in use during the first half of the $5^{\text {th }}$ century. Based on the Visegrád fragment's design, it can be placed also in the later group.

Among the fragments of unidentifiable bowl forms, glazed on the inside (17 pieces), there are two foot fragments; the rest are wall fragments. Of these the fabric of 3 is whitish-yellow, gritty, hard-fired. On another fragment there are traces of wheel (2013.14.15.4.).

Jugs (39 pieces) $)^{50}$

Belonging to this group are the neck and wall fragments, feet (6 pieces) and band handles (4 pieces) with glaze on the outside. One of the broad, tripartite handles belonged to a large jug (2013.14.6.89.), with burnt glaze on it. ${ }^{51}$ On another there is only a glaze spot (2013.14.20.26.: its fabric white, gritty). There are few rims (3 pieces) and even fewer intact vessels (1 piece).

${ }^{44}$ CVjetićanin 2006, 34, LRG 24 (impressions on the neck), 43, LRG 42 (wavy line on the rim), 51-53, LRG 69a, 70 (S-profile); GRÜnEwAld 1979, Table 67.2; JelinčIĆ 2015, Table 151.91 (impressions on the rim: $3^{\text {rd }}-$ early $5^{\text {th }}$ century).

${ }^{45}$ OtTOMÁnYi 2015a, 28-29, Fig. 11.3, 6 (notches on the rim); OTTOMÁNYI 2018b NW tower (Fig. 4.2-3: notches and circular impressions); ОттомÁNYi 1999, 337, Pl. I.9-10 (Dunabogdány); GrünEWALD 1979, 71, Table 67.9; Tomka 2004, Table 3.3 (Györ, phase 1B); CVJETIĆANIN 2006, 56, LRG 75. bowl with circular impressions on the rim; Jeremić 2012, Fig. 3. Cat. no. 206., 210., 211. (Saldum, Valentinian period).

${ }^{46}$ OtTományi 1991, 15, Table 1.5,8 (Leányfalu); OtTományi 1999, 336, Pl. I.1-4 (Dunabogdány); FriesingerKerCHLER 1981, Fig. 7.2; MikLÓsITY SzŐKe 2008, 165, Table III.4-5 (Brigetio); BónIs 1991, 131, Fig. 5.6 (Tokod); OTTOMÁNYi 2011, 267, Table 2.1 (Budaörs, turn of the $4^{\text {th }}$ and $5^{\text {th }}$ centuries); CVJETIĆANIN 2006,49 , LRG 61 (turn of the $4^{\text {th }}$ and $5^{\text {th }}$ centuries); OTtomÁNYISosZTARITS 1998, Table III.7-8 (mid- $5^{\text {th }}$ century, Szombathely).

${ }^{47}$ Otтományi 2015a, 29, Fig. 3.2, Fig. 7.10.

${ }^{48}$ OtTOMÁNYI 1991, 15, Table 2.11-12a (the colour of the glaze is yellowish-brown); ОттомÁNYi 1996, 95, Fig. 3.6,6a; OTTOMÁNYI 2004, 269, Table I.6-7 (with further analogies); GASSNER 2000, 217, Fig. 185 (Mautern).
${ }^{49}$ OtтomÁnYi 2011, 266-267, Table 2.6-8, Table 6.3 (Budaörs: coins between 351 and 375); NÁDORFI 1992, 50, Table II.3a-b; BóNIS 1991, 131-133, Fig. 18.2 and pottery workshop: Fig. 10.5; HORVÁTH 2011b, 210, Fig. 94.K229 (late- $3^{\text {rd }}$ century-Valentinian period).

${ }^{50}$ There are a few additional, thin wall fragments, which may equally belong to jugs or mugs. I currently included them with the mugs based on their colour and design (8 pieces, probably Leányfalu-type). The form of many wall fragments glazed on the outside is uncertain (they might have been mugs as well). Based on its fabric, a red small jug fragment with white slip on the outside may have been glazed, although no glaze remained on its exterior (Fig. 6.4).

${ }^{51}$ In the south wing of the fort a conspicuously high number of such large glazed jugs with one or two handles were found (OtTOMÁNYi 2015a, 30-31, Fig. 3.8, Fig. 12.1). Also found in the west wing, in the burnt, daub debris (OTTOMÁNYi 2015b, Fig. 7.5, Fig. 10.2); in room I/N (OtTOMÁNYi 2018c, Fig. 2.3: of yellowishwhite fabric, with collared rim); In Pannonia, during the late $-4^{\text {th }}$ century, large glazed jugs appear in other sites as well with different rims, e.g. Budaörs: (OtTománYi 2011, 269, Table 4.11); Tokod: BóNIs 1991, 135-139, Fig. 7.1, Fig. 8.13; Moesia, Dacia: CvJETIĆANIN 2006, 8182, LRG 126-128 (amphora, second half of $4^{\text {th }}$ century). 


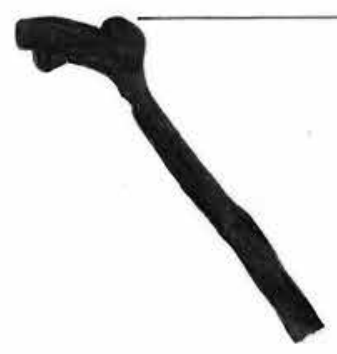

1

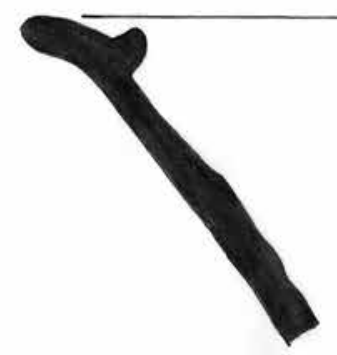

3

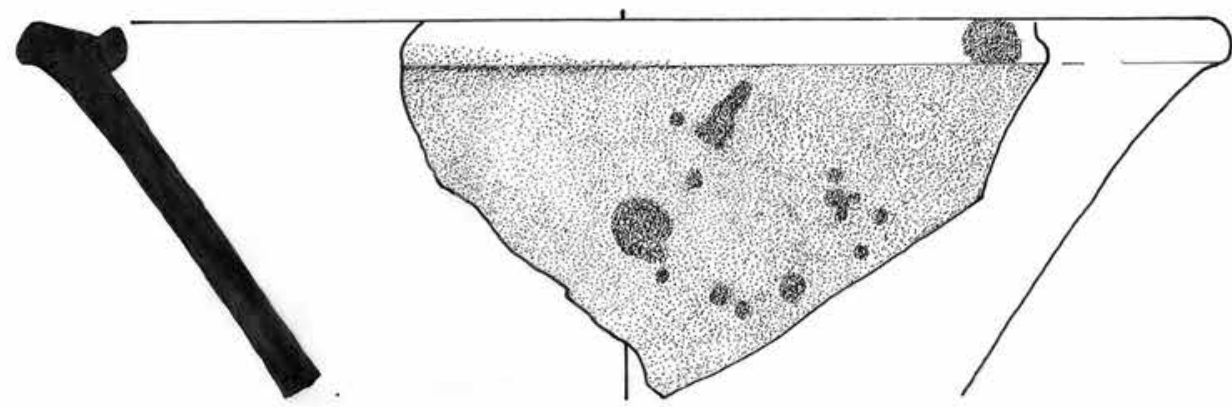

2013.14.6.88

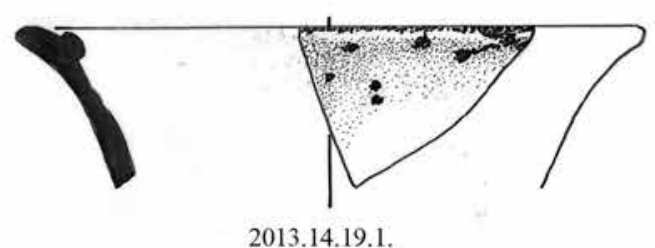

4

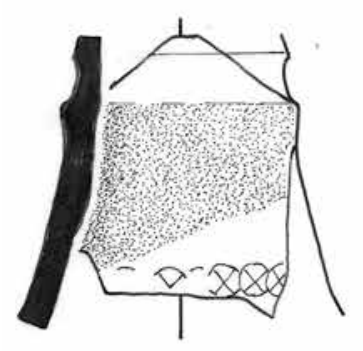

2013.14.1.9.

5

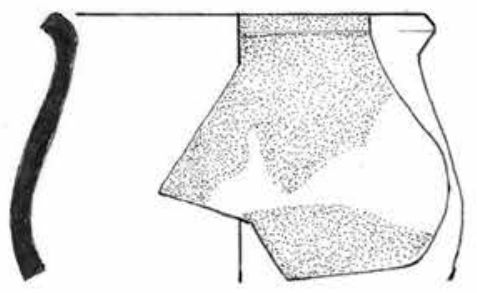

2013.14.20.2.

6

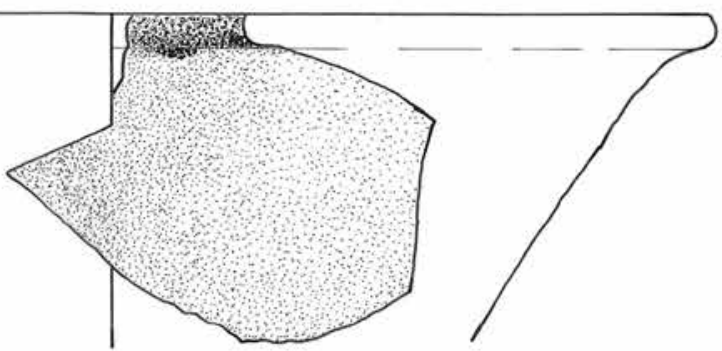

2013.14.21.1.

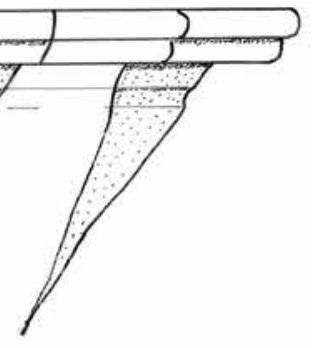

2013.14.4.1.+2013.14.21.2. 


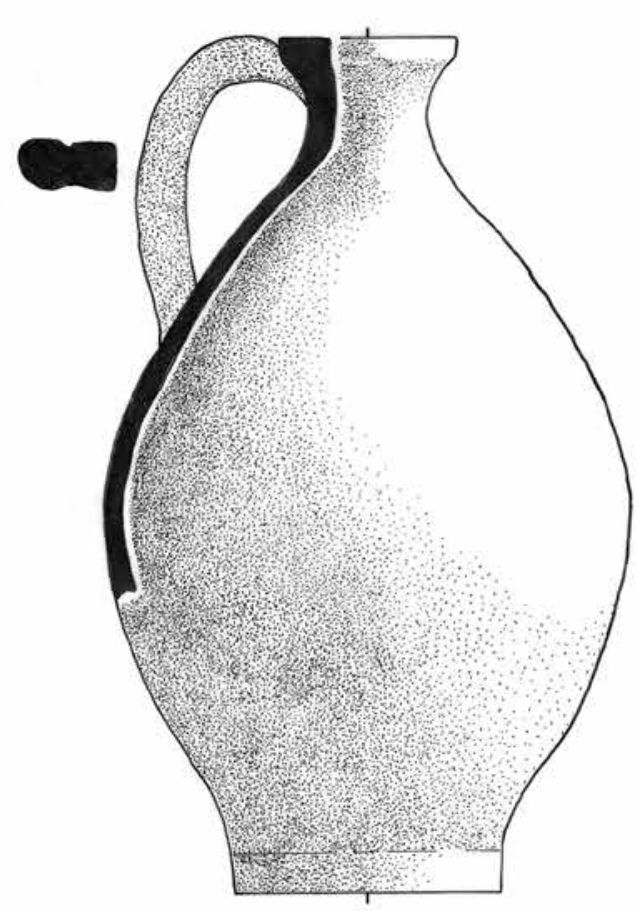

1

2013.14.7.1.
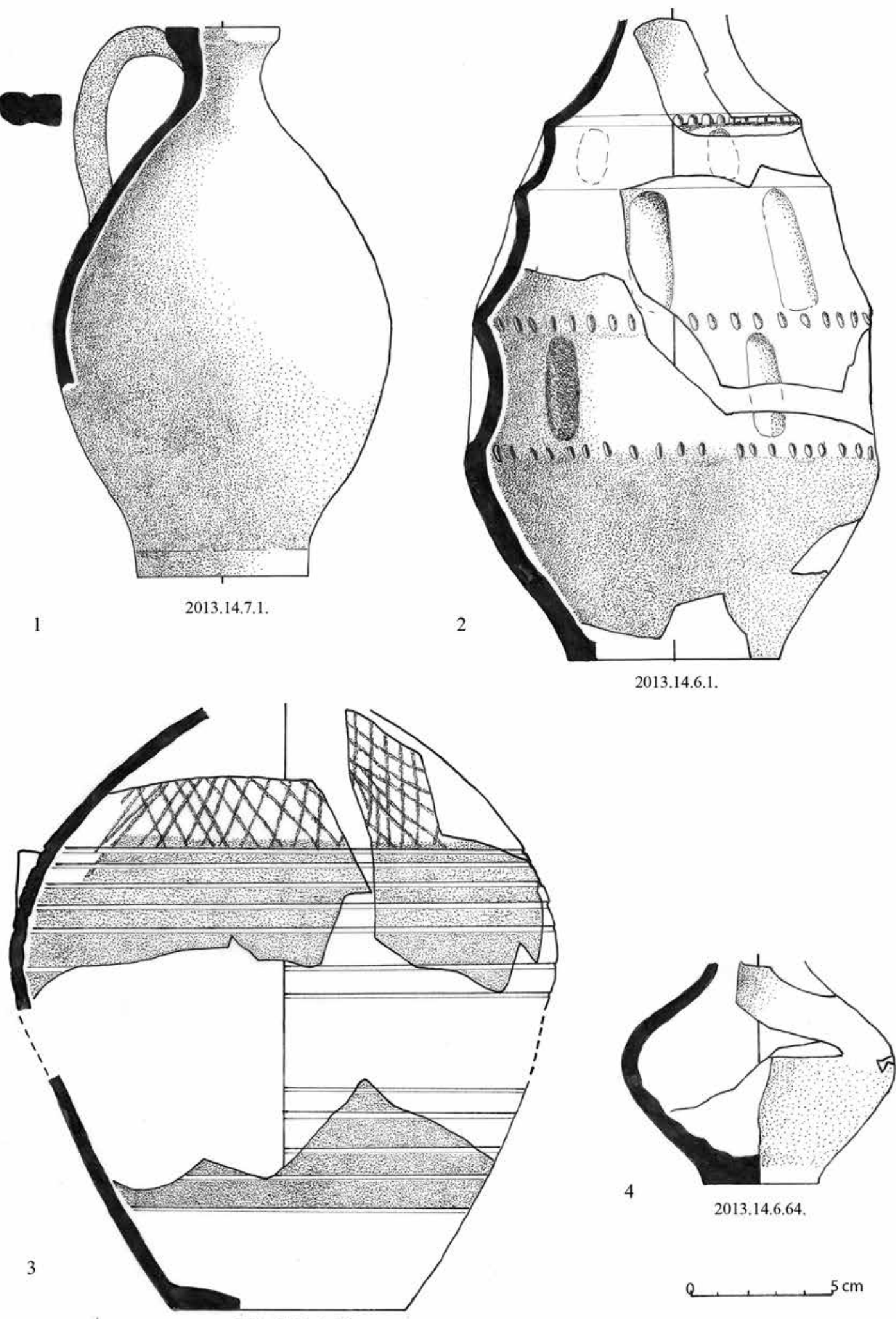

2013.14.22.5.+13.

Fig. 6. Glazed (1-2), smoothed-in (3) and brick-coloured (4) jugs

Acta Archaeologica Academiae Scientiarum Hungaricae 71, 2020 
Jugs with handles and narrow necks: Most narrow neck fragments feature one or more ribs (4 pieces). Around the neck of one run stamped circular motifs, with burnt green glaze on it (Fig. 5.5, Fig. 10.3). On the everted rim fragment (2013.14.15.6.) there is a band handle start with shiny dark brown glaze. On the upright, segmented rim there are traces of burnt glaze (2013.14.17.4.). They probably belonged to jugs with handles and narrow necks, which, with different rim variants, were widely used in the $4^{\text {th }}$ century. ${ }^{52}$ The only intact vessel was found in the infill of the room's flue.$^{53}$ It probably ended up there when the flue was filled in (Fig. 6.1; Fig. 10.1). It was likely used for a long time; the green glaze on its surface is worn, its wall is punctured in one place. Its form, oval body and widening rim, is typical mostly for the second half of the $4^{\text {th }}$ century, but it continues until the end of the century. ${ }^{54}$ Its position and condition indicate that it was hidden at the very end of the $4^{\text {th }}$ century. Several, almost intact glazed jugs were found in this part of the fort, e.g. two in front of the NE entrance of the west wing. ${ }^{55}$

Jug with collared rim (2013.14.2.1.): Its fabric is yellowish-white, gritty, hard-fired, with shiny brown glaze on the inside. The form appears at the turn of the $4^{\text {th }}$ and $5^{\text {th }}$ centuries, usually common with smoothed-in decoration and as household pottery. In Visegrád-Gizellamajor it appears with glazed surface in several places, in the upper destruction debris (room III/N), or under the daub debris (west wing).$^{56}$ It mostly appears in glazed form where it was produced locally, e.g. Leányfalu, Tokod. ${ }^{57}$

Jug with a dented wall (Fig. 6.2): Unique form; its profile can be nearly reconstructed from the fragments (its rim is missing). Its fabric was hard-fired, micaceous, with dark green and in places secondarily burnt glaze. Its decoration, bands of dented and notched ornaments, is typical for the time when glazed pottery stopped being used. It is from the upper daub layer. A more slender jug with a similar form and decoration was found in Leányfalu; its heavily segmented collared rim and handle start also survived (made of a gritty, porous fabric, fired greyish-black, without glaze, with incised wavy line). ${ }^{58}$ Perhaps both were made by the same potter. Dents also appear on a glazed bowl in room IIb/N of the Gizellamajor fort. ${ }^{59}$

The earlier jugs with medium-hard fired fabrics are red, reddish-grey with green, greenish-brown glaze. The later jugs, hard-fired, are dark grey with green glaze. The latest are the yellowish-white, whitish-grey collared jug rim fragment and band handle with glaze spot, as well as the thin wall fragments made of a gritty fabric, which could have belonged to a jug or equally a Leányfalu-type mug.

Mug/pot (14 pieces)

Belonging here are two rim fragments as well as a few wall fragments glazed on the outside ${ }^{60}$ The traditional mug forms with an everted rim are earlier. ${ }^{61}$ They are red, with burnt, perhaps green glaze on the one (Fig. 5.6), and a yellowish-brown glaze spot on the other (Fig. 14.2). Based on its medium-hard fired fabric, it may have been originally glazed, although it is possible that the glaze spot only ended up on the household pottery mug during firing. Glazed or glaze-spotted mugs with an everted rim were also found in the south wing. ${ }^{62}$

Leányfalu-type mugs/pots: based on their distinctive shoulder carination, two fragments certainly belong to this type (Fig. 5.7; 2013.14.6.117.). They are reddish-grey and light grey. Other thin wall fragments, fired yellowish-grey, of a 'ringing' hard and gritty fabric, too, may probably be included here (10 pieces). The shoulder of one was ribbed with traces of wheel (2013.14.20.6.). Their find-spot is the upper daub layer (2013.14.6.21-22.,

${ }^{52}$ OттомÁNYI 1991, 18-19, Table 17.15, 17, Table 18.21, Table 20.30, Table 21.31-32 etc. with detailed references and analogies; BÓNIS 1991, 135, Fig. 5.7,9, Fig. 11.18, 20; NÁDORFI 1992, 4547, Table 1; CVJETIĆANIN 2006, 57-64, LRG 80-88.

${ }^{53}$ Hidden inside the heating flue: an intact jug, military brooch, clasp, beads (by the entrance, under a roof tile). A little farther: double-sided bone comb. See: GRÓH 2000, 28, Fig. 1.3.

${ }^{54}$ LÁNYI 1972, Fig. 37.2; NÁDORFI 1992, Table I.6, 8a-b; Intercisa (HoRvÁth 2011b, 207, Fig. 92.K185, K193, K196); CVJETIĆANIN 2006, LRG 84, 88 (second half of $4^{\text {th }}$ century).

${ }^{55}$ OtTOMÁNyi 2015b, Fig. 8.1,3. the daub debris)

${ }^{56}$ OTTOMÁNYI 2012, table (zs/5. and 33: stony debris, under

${ }^{57}$ OTTOMÁNYI 1991, 17-18, Table 15.1,2a, 4a, Table 16.89, Table 17. 14 (half of the jugs belongs to this type); BóNIS 1991, Fig. 17.6; LÁNYI 1981, Fig. 3, Type III (household pottery); ŠvaŇA 2011, Fig. 4.1. (Iža: after Valentinian).
${ }^{58}$ OtтомÁNYI 1991, Table 18. 22; same kind of glazed rim from room I/N (OtTOMÁNYI 2018c, Fig. 3.3).

${ }^{59}$ OTtOMÁNYI 2015b, Fig. 7.4 (Room IIb/N, dark brown layer under upper mortary layer); also found in Brigetio and the Iža fort opposite (MiKLósITY SzŐKE 2008, 163, Table II.1-2; ŠVAŇA 2011, Fig. 6.5).

${ }^{60} \mathrm{I}$ included the majority of externally-glazed wall fragments with jugs, as mugs with a glazed surface are rare. The thinwalled pieces fired yellowish-white are exceptions. They likely belonged to the so-called Leányfalu type, hence they are included here (8 pieces).

${ }^{61}$ MiKLósity SZŐKE 2008, 166, Table IV.

${ }^{62}$ OtToMÁnyi 2015a, 31, Fig. 12.3 (room III/S), Fig. 19.6 (SE tower); Analogy e.g. from Leányfalu (OTTOMÁNYI 1991, Table 22.1: mug with handle); Mugs with an everted rim with glaze spots and glaze streaks in Budakalász-Luppacsárda (ОтTOMÁNYI 2004, 270, Table IV.5-6); MiKLósity SzÖKE 2008, 166, Table IV.5. 
2013.14.20.3-6. and 2018.1.13.2-5.). Their glaze is light coloured, blistered by fire. In places it can be seen that glaze likely used to be light green. Only a thin layer of glaze was applied, and does not cover the whole surface. This type appears on a range of sizes from small mugs to large pots. It has many variants in the fort. It appears usually as household pottery, but in areas where it was made locally, e.g. Leányfalu, Tokod, it also has glazed variants. ${ }^{63}$ That is also the case in Gizellamajor. ${ }^{64}$ This type, which appeared in the last third of the $4^{\text {th }}$ century, remains common until the mid- $5^{\text {th }}$ century. ${ }^{65}$

New vessels forms at the turn of the $4^{\text {th }}$ and $5^{\text {th }}$ centuries

If we look at the latest, early- $5^{\text {th }}$ century vessel forms, it is not the number of items that counts, but the ratio within the given forms (Fig. 3.3). Most common are the thin-walled, probably Leányfalu-type vessels $(85.7 \%$ of mugs), which indicates that mugs were rarely glazed earlier. The other form, where half of all pieces are late vessels, is the bowl with a horizontal rim. Here, too, is a new type with a conical base and shoulder carination, which only appears on the latest vessels. 4 pieces might be jugs. Two were fired white, with a gritty fabric (collared rim, glazespotted handle); the other two were placed in the late group due to their decoration (stamped wall and dented wall with impressions). These two were secondarily fired, with reddish-grey layers. Indicating the long life of mortaria is that these vessels, which appeared the earliest, were still in demand in the first half of the $5^{\text {th }}$ century. At the same time, this also indicates ethnicity: a part of those who used glazed vessels continued to maintain Roman eating habits even in the $5^{\text {th }}$ century.

\subsubsection{Decoration}

The earliest ornament on glazed pottery is stitched decoration (on a cup with three handles), which appeared already during the middle third of the $4^{\text {th }}$ century. The plastic ornaments are all later: impressions (on jug shoulder: Fig. 10.2; on the rim of horizontal bowls), wavy rims (on bowls with a horizontal rim), as well as incised wavy lines (on horizontal bowl rims). These are more characteristic of the second half of the century and live on also during the first half of the $5^{\text {th }}$ century. ${ }^{66}$ Jugs with dented walls, decorated with notches, however, belongs to the latest, $5^{\text {th }}$ century group (although its fabric is not fired white). Stamped ornaments are much rarer. There is such a jug neck in room III/N: circular stamped motifs (with an $\mathrm{x}$ in their middle) can be seen on a narrow-necked jug with burnt green glaze (Fig. 5.5). The other stamped vessel decorated with rosettes in the north wing is yellowishbrick-coloured, unglazed. ${ }^{67}$ As an analogy we can mention the stamped household pottery from the Tokod fort, the origin of which the author traces to the African red slip bowls arriving from the Mediterranean. ${ }^{68}$ There simple, circular stamp-marks can also be observed on glazed pottery, the handle of a so-called snake-vessel. ${ }^{69}$ Stamped rosettes are also attested in the Barbaricum, not on glazed, but on household pottery (e.g. in the Upper Tisza region), or on surfaces smoothed shiny. ${ }^{70}$ It is therefore unlikely the custom came from there.

The strong traces of wheel, which can be observed on the shoulder and belly of Leányfalu type mugs and the upper part of a bowl, can be considered also as decoration ( 3 pieces). ${ }^{71}$ It can be traced from the turn of the $4^{\text {th }}$ and $5^{\text {th }}$ centuries until the mid- $5^{\text {th }}$ century. ${ }^{72}$

${ }^{63}$ It is also called Tokod pottery. Not only this form, but also the vessels, fired 'ringing' hard, of a very gritty fabric, too, are placed in this category. LÁNYI 1981, 75, Type I, Fig. 1-2; OTTOMÁNYI 1991, 20, Table 28-32. 39b, 42, 50a, 60, 63. Typ. Some only have a glaze spot.

${ }^{64}$ West wing, daub, mortary debris layer: OTTOMÁNYI 2015b, 714, Fig. 11.1.

${ }^{65}$ CVJETIĆANin 2006, 93-94, LRG 170 (5 $5^{\text {th }}-6^{\text {th }}$ century).

${ }^{66}$ Otтомányi 2015a, 31-32 (with further analogies); ŠVAŇA 2011, 245, Fig. 4a-b (Iža: after Valentinian-early- $5^{\text {th }}$ century).

${ }^{67}$ OtтомÁnyi 2015b, 703-708, Fig. 5.5 (between west and north building, room IIb/N, under $2^{\text {nd }}$ floor); In room III/S with circu-

Acta Archaeologica Academiae Scientiarum Hungaricae 71, 2020 lar stamp-marks between the incised wavy lines, both as glazed and household pottery (OTTOMÁNYi 2015a, 32, Fig. 17.2).

${ }^{68}$ LÁNYI 1981, 82, Fig. 24.

${ }^{69}$ BóNIS 1991, 141, Fig. 12.7; GRÜNEwald 1979, 69, Table 102.2 (late $3^{\text {rd }}-$ late $4^{\text {th }}$ century).

${ }^{70}$ Gindele-Istvánovits 2009 , Table $81.1\left(5^{\text {th }}\right.$ phase of pottery: mid- $3^{\text {rd }}-4^{\text {th }}$ century); PollaK 1980 , Table 29.2 (Kleinmeiseldorf: polished surface, $4^{\text {th }}$ century)

${ }^{71}$ The fabric of the bowl fragment decorated with traces of wheel is not late (medium-well levigated, with yellowish-brown glaze: 2013.14.15.4.)

${ }^{72}$ E.g. south wing (OtтомÁNyi 2015a, 32, Fig. 3.8, Fig. 12.1). For more details see the section on household pottery! 


\subsection{Pottery with smoothed-in decoration}

We can find smoothed-in decoration on 19 fragments altogether. The shiny, smoothed-in pattern which appears on the matt surface is what makes these vessels ornamental pottery. All are serving bowls; the larger ones may have been also used for storage. Their material, finely-shaped and well-levigated, was not suitable for cooking vessels.

\subsubsection{Smoothed-in decoration method, colour and fabric}

With one exception, smoothed-in decorations are all shiny. Sometimes in the case of a single vessel, the smoothed-in decoration is shiny on one fragment, while it is worn and barely visible on the other (e.g. Fig. 9.4). Usually, the smoothed-in decoration matches the colour of the fabric; only in 3 cases is it darker (Fig. 6.3; Fig. 7.9). One of these decorations is shiny black on a dark grey jug (Fig. 8.1). Another fragment of the same jug is brownishgrey with a darker smoothed-in decoration, though not fired black. The colour and the smoothed-in decoration's shine, therefore, depends not only the surface treatment but also on the firing method. ${ }^{73}$ The pattern consists mostly of thick lines ( 7 pieces: vertical bands, wavy line, lattice pattern), only in the case of two jugs with lattice pattern, one jug with diagonal lines, as well as a biconical bowl does the smoothed-in pattern consist of thin lines (Fig. 6.3; Fig. 7.8; Fig. 8.2-3). These are the products of different potters who used different tools for the smoothed-in decoration.

The colour of the fragments is usually grey (15 pieces). There is also a light brown, a reddish-brown and two dark red fragments. Some of the red fragments were fired grey in places (Fig. 6.3). Their fabric is well-levigated, half were medium-hard fired, one was soft-fired (reddish-brown jug: Fig. 9.4). The other half of the vessels were hard-fired (9 pieces), which, with two exceptions, are grey. ${ }^{74}$ One of them is a fragment with a gritty fabric (2013.14.9.6.: smoothed-in with diagonal bands).

There are no waster fragments in the north wing.

\subsubsection{Pattern}

The composition of the patterns is varied; no one motif dominates. Most common is the vertical line/band, followed by lattice pattern and wavy line. There are no unique motifs; although the pattern on the shoulder of a jug is difficult to interpret due to its fragmentary nature.

Vertical line/band: Most common is the vertical line or band (12 pieces). On two fragments we can observe wider bands; on the inside of two bowls and on the neck of a jug, the dense vertical smoothed-in ornaments form an almost contiguous surface (2013.14.13.23.; Fig. 7.3; Fig. 9.2) ${ }^{75}$ Sometimes the vertical lines appear on a vessel on their own, e.g. on the neck of a biconical bowl (Fig. 7.8). When they decorate the neck of a jug, probably there once was another pattern below, even if it has not survived (Fig. 9.2; 2013.14.1.39; 2013.14.3.29.). Frequently they are combined with a wavy line (e.g. belly of a biconical bowl: Fig. 7.9; neck of a jug: Fig. 8.1) or lattice pattern (Fig. 9.3-5).

Diagonal lines appear on the neck of a jug (Fig. 8.2) and diagonal bands appear on the shoulder of three other jugs (2013.14.9.6; Fig. 8.3; Fig. 9.3).

Lattice pattern: 6 instances. Sometimes on its own (Fig. 6.3; Fig. 8.4), however, mostly combined with other motifs (usually vertical lines) (Fig. 8.3; Fig. 9.3-5). They most frequently appear on jug necks.

Wavy line motif appears on the belly of a biconical bowl and the shoulder of a jug, in both cases in a band, below or above a vertical line. The wavy line motif on the jug follows a regular, zigzag-like pattern (Fig. 8.1). On the other vessel features an irregular double-wave motif.

\footnotetext{
${ }^{73}$ MASEK 2011, 253-254.

${ }^{74}$ The exceptions being a red jug with grey spots (Fig. 6.3) and a light brown, biconical bowl (Fig. 7.9).
}

\footnotetext{
${ }^{75}$ There are neck fragments, where the vertical smoothedin ornaments are wholly contiguous (e.g. 2018.1.13.21.); these I discuss in the section on smoothed vessels. On the inside of bowls, smoothed-in vertical lines are usually rare (they are mostly horizontal). For the analogies see the section on vessel forms.
}

Acta Archaeologica Academiae Scientiarum Hungaricae 71, 2020 
1

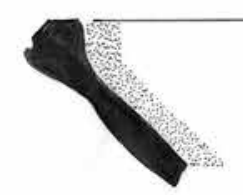

(f)

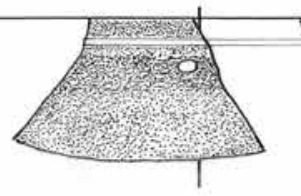

2013.14.5.3. + 2013.14.9.3.

2
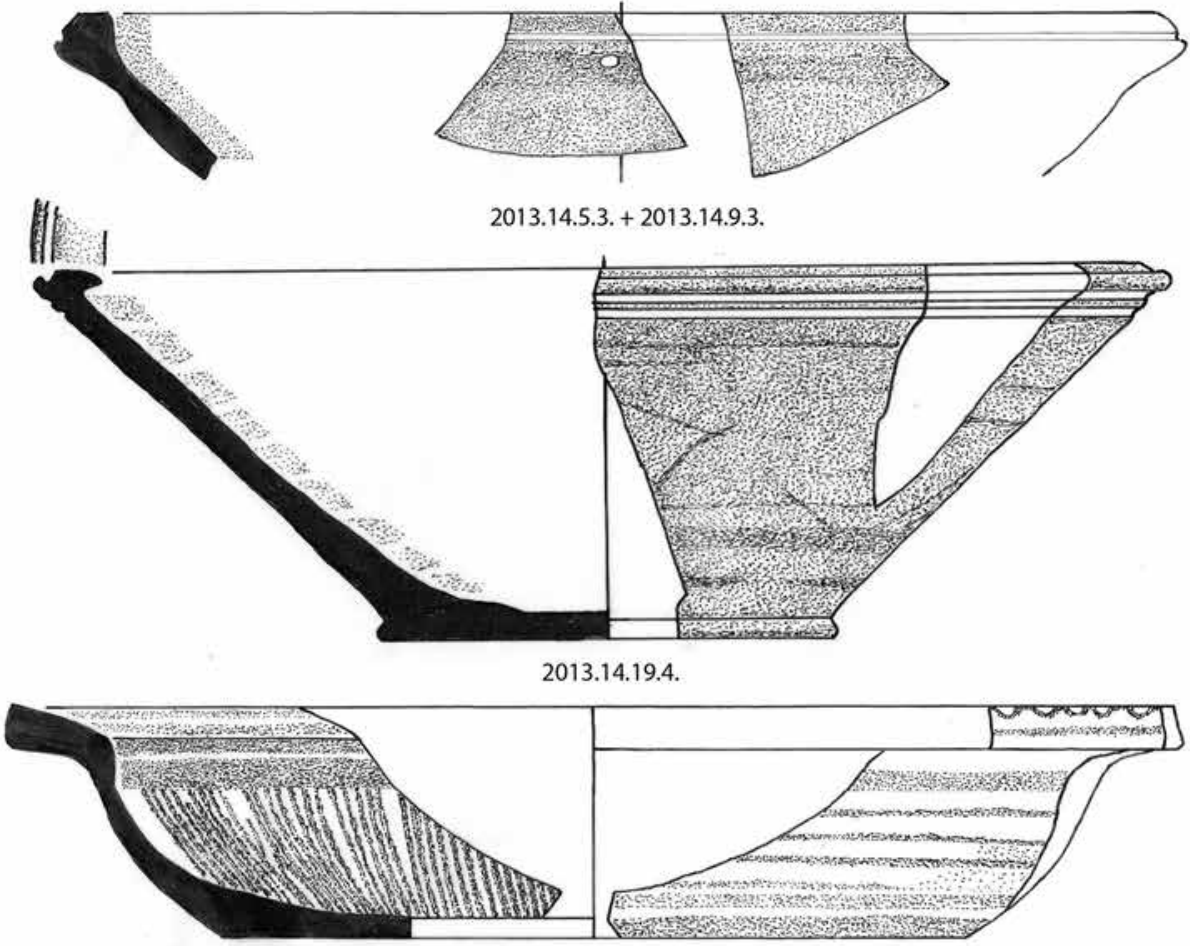

2013.14.1.20.

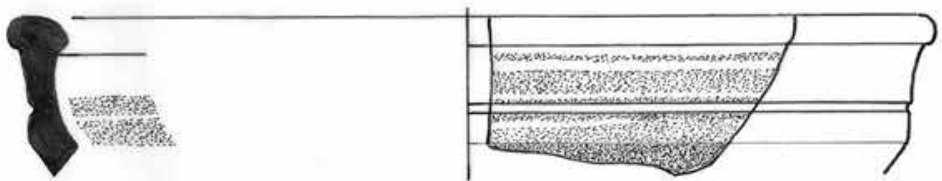

4

2013.14.1.18

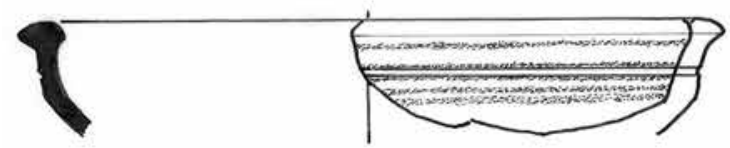

2013.14.1.21. + 2013.13.23.4.

5

6
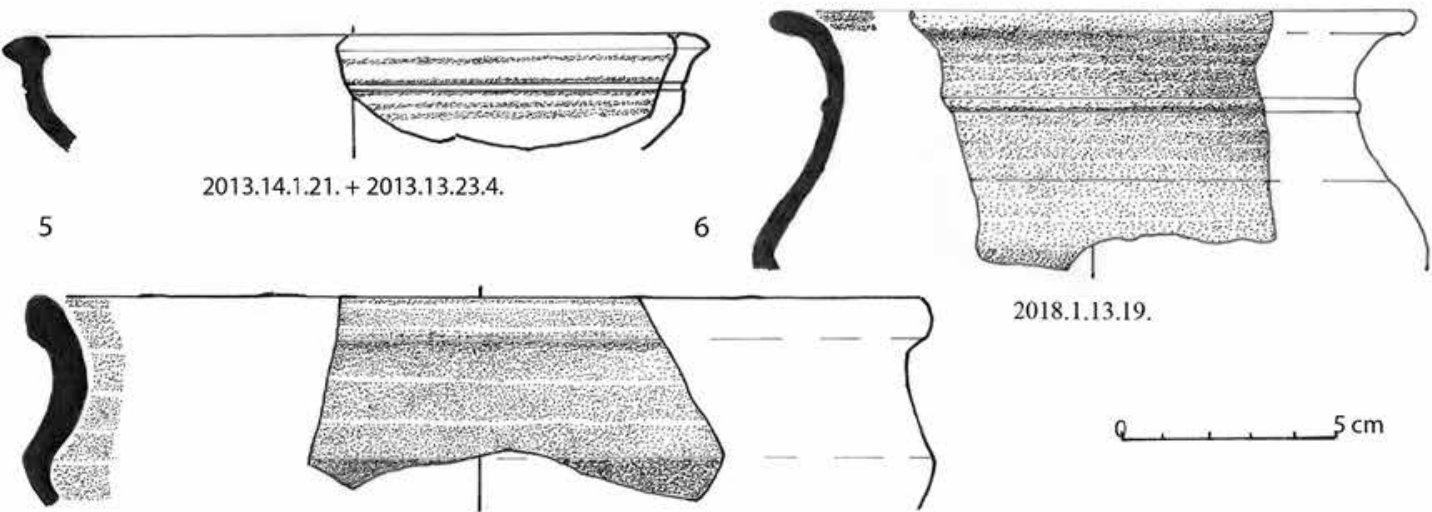

2018.1.13.19.

7

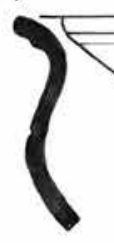

8

2013.14 .4 .13

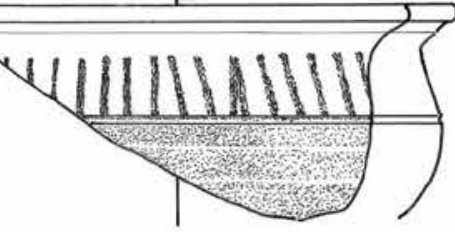

2013.14.6.33.

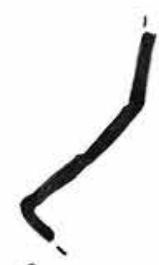

9

Fig. 7. Smoothed and smoothed-in bowls

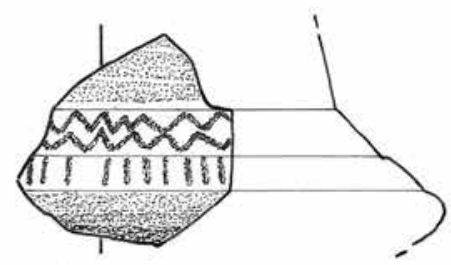

2013.14.6.52.

Acta Archaeologica Academiae Scientiarum Hungaricae 71, 2020 


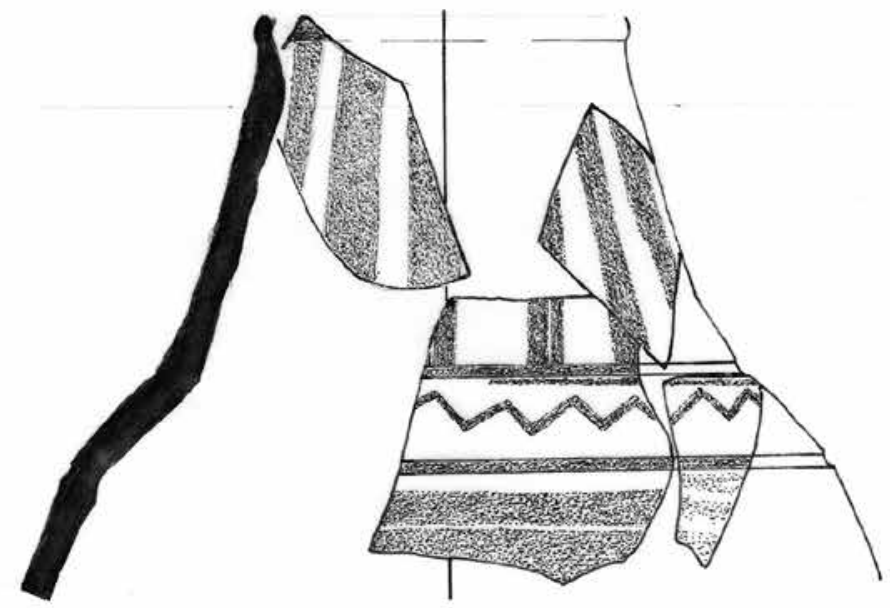

2013.14.23.1. + 2013.13.6.238
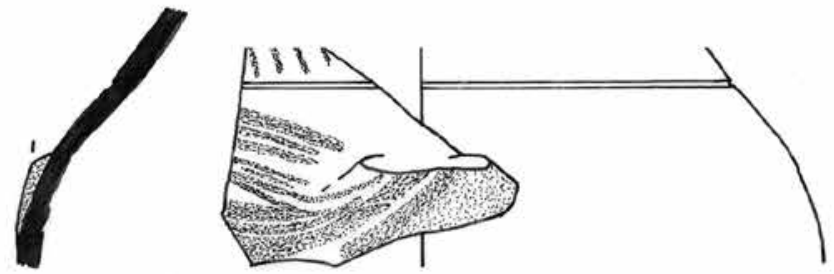

2

2013.14.12.11.

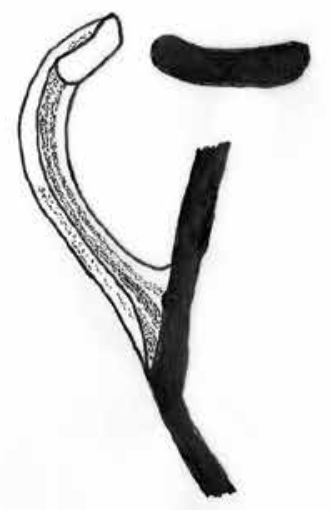

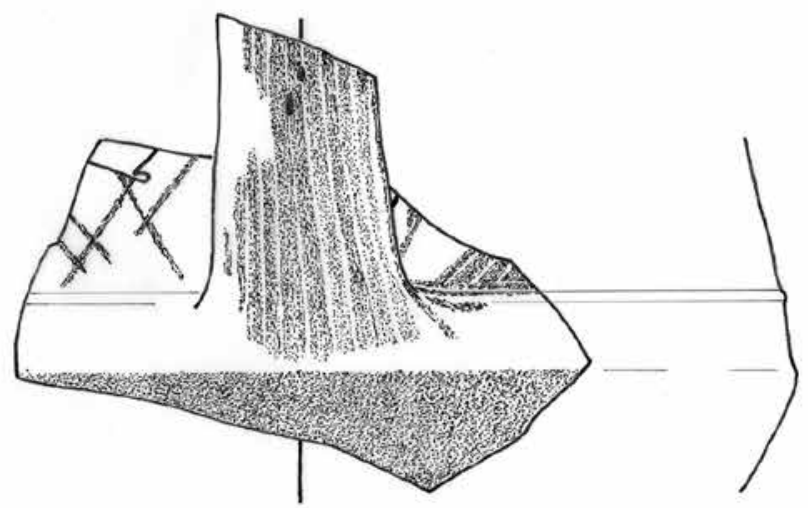

2013.14.17.9.
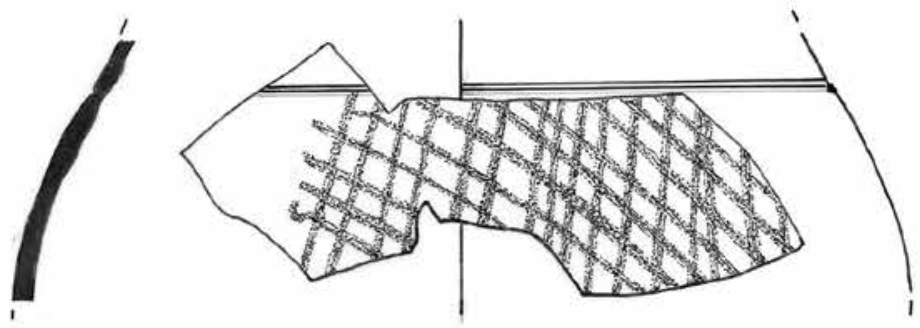

2013.14.1.37 $5 \mathrm{~cm}$

Fig. 8. Jugs with smoothed-in decoration

Acta Archaeologica Academiae Scientiarum Hungaricae 71, 2020 

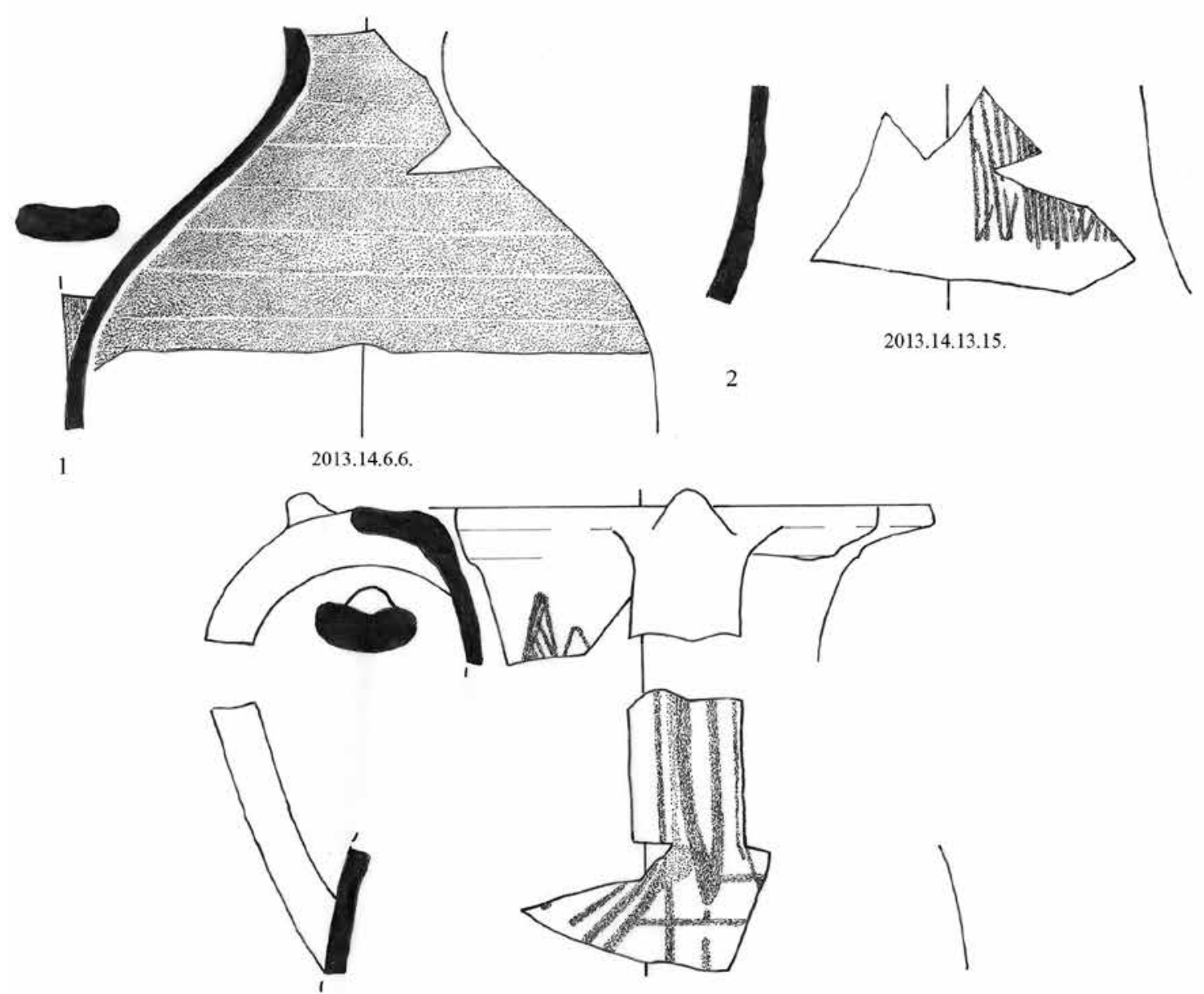

3

2013.14.13.12.

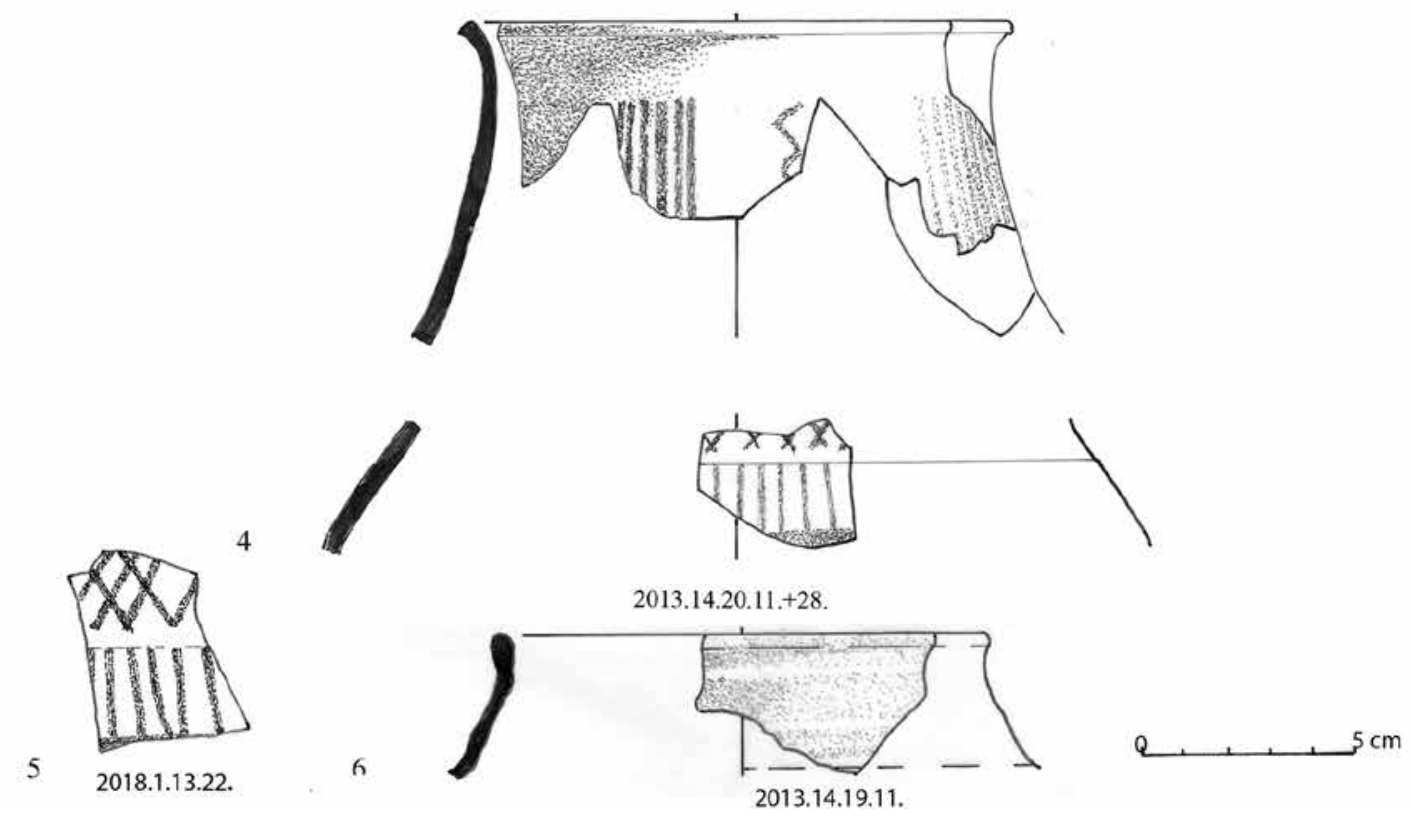

Fig. 9. Smoothed and smoothed-in jugs, mugs

Acta Archaeologica Academiae Scientiarum Hungaricae 71, 2020 
As part of a Murga-type motif a vertical wavy line can be seen on the neck of a pitcher (Fig. 9.4.). The pattern on the jug neck of Fig. 9.3 (standing wave, triangle filled with diagonal lines?, with a lattice pattern below) is unclear.

Sometimes the ornaments are arranged in bands (around 3 pieces). We find these mostly on the shoulders of biconical bowls and jugs. More commonly, the various parts of the vessel (neck, shoulder, belly) are decorated using different patterns, separated by a protruding shoulder or a groove. On smaller fragments the pattern of the ornaments is unclear (e.g. 2013.14.1.40.). Handles were smoothed vertically (this is surface smoothing rather than smoothed-in decoration). See Fig. 8.3; Fig. 9.3. Under the handles the smoothed-in decoration usually breaks. The belly and lower half of the vessels are, in all cases, covered by contiguous, horizontal smoothing. The body of two large jugs, below the smoothed-in ornament, is decorated with flat ribs (traces of wheel), the surface of which was smoothed horizontally (Fig. 6.3; Fig. 9.4). On the vessels incised patterns do not appear, only incised/sunken dividing lines between the smoothed-in bands. On the bowl with horizontal rim, vertically smoothed-in on the inside, the rim on the outside was fashioned wavy-shaped using impressions, just like on similar-shaped glazed bowls in this late period.

\subsubsection{Form}

\section{Bowl (4 pieces)}

Two are Roman forms, two are new, $5^{\text {th }}$ century types. The two forms with Roman roots are covered on the inside almost contiguously by vertical bands. ${ }^{76}$ One of them is a deep bowl with an inverted rim (2013.14.13.23.). This form was characteristic of late Celtic, $1^{\text {st }}$ century vessels. It reappears from the second half of the $4^{\text {th }}$ century in glazed (Fig. 4.1), smoothed or smoothed-in versions. ${ }^{77}$ It was found during the removal of the stone debris.

The horizontally everted rim of the other bowl was fashioned wavy-shaped. Its surface is covered by smoothed bands: horizontal on the outside, vertical on the inside (Fig. 7.3). It comes from the upper, stony, brown layer. Its form can be observed on glazed vessels from the second half of the $4^{\text {th }}$ century, though its origins can be traced to the African red slip types. ${ }^{78}$ A glazed bowl with a similar form, with smoothed bands on the outside, was found in the upper daub layer of room III/N and the gravelly layer of the foreground of room IV/S (Fig. 4.4). At the Leányfalu watchtower, this form was manufactured with a rim with a smoothed-in wavy line. ${ }^{79}$ At the Balatonalmádi kiln it was produced smoothed on the inside, with a wavy rim during the final third of the $4^{\text {th }}$ century. ${ }^{80}$

New types are the two biconical bowls. Both come from the upper daub layer. One of them is more spherical, with vertical lines on its shoulder (Fig. 7.8). ${ }^{81}$ The belly of the other is sharply carinated, with two bands of smoothed-in motifs on the shoulder (wavy line and vertical lines) (Fig. 7.9). Its form appears already at the turn of the $4^{\text {th }}$ and $5^{\text {th }}$ centuries, becoming widespread during the middle, second half of the $5^{\text {th }}$ century (it even lives on in Lombard/Gepid pottery). The smoothed-in wavy line motif is most prevalent in Moravian territory. ${ }^{82}$ Many varieties of biconical bowls with smoothed-in decorations have been found at Gizellamajor. There are no two identical types among them. ${ }^{83}$ In the Danube Bend several workshops produced them locally at the turn of the $4^{\text {th }}$ and $5^{\text {th }}$ centuries. In Pilismarót-Malompatak they featured ornaments organised into bands, in Leányfalu they featured lattice motifs. ${ }^{84}$ None of them resemble the vessels of room III/N.

\footnotetext{
${ }^{76}$ They could belong to the smoothed vessels, but the vertical lines/bands are clearly separate from each other.

${ }^{77}$ In the south wing: OTTOMÁNYI 2015a, Fig. 4.1, Fig. 8.1, Fig. 13.1 (smoothed), Fig. 8.3 (smoothed-in with vertical lines); at forts along the Limes in many places e.g. Carnuntum, Mautern, Boiotro, Klosterneuburg etc. Dated to the turn of the $4^{\text {th }}$ and $5^{\text {th }}$ centuries: FrIESINGER-KERCHLER 1981, Fig. 3.5, 13, Fig. 27.5; GRÜNEWALD 1979, Table. 71.2-3 (Fabr. B); GASSNER 2000, 237, Fig. 198; UBL 1986, Fig. 20; GroH-SEDLMAYER 2002, 235-236, Fig. 144. 728, 1180 $\left(4^{\text {th }} / 5^{\text {th }}\right.$ century); GROH-SEDLMAYER 2013,504 , Fig. 8 (period 5).

${ }^{78}$ GrOH-SEDLMAYER 2002, 184 (Hayes form 69) FrIESINGERKERCHLER 1981, Fig. 9.5 (Mautern).

${ }^{79}$ OTTOMÁNYi 1991, Table 12.62 (glazed, with smoothed surface on the outside: Table 12.63; household pottery: Table 12.64).

${ }^{80}$ PalÁgyi 2004, 54, Fig. 19.11. (along with similarlyshaped glazed bowls).
}

\footnotetext{
${ }^{81}$ Similar decorations on biconical vessels e.g. WienAspern (Friesinger-KerChler 1981, Fig. 26.4); TEJRAL 1985, Fig. 18.5 (Lovčićky).

${ }^{82}$ TomKA 2004, Table 3.9 (Györ, Migration Period phase 1B); Friesinger-Kerchler 1981, 261-263, Fig. 42-43 (Lower Austria: lattice pattern); TEJRAL 1985, Fig. 17.2-3 (Mackovice, Vyškov: wavy line); etc.

${ }^{83}$ South wing (OтTOMÁnYi 2015a, Fig. 14.7, Fig. 16.9); west wing (ОттомÁNYi 2015b, Fig. 12.1-2, Fig. 14.1); south courtyard (OtTománYi 2018a, 108, Table 6.2-3); On the Sibrik hill (Visegrád), in a pit dug at the Roman fort, there was a biconical bowl fragment decorated with a smoothed-in lattice motif (SOPRONI 1985, 63, Table 12.2).

${ }^{84}$ OtтomÁnyi 1996, 85, Fig. 5.29 (Pilismarót-Malompatak); OттомÁNYi 1991, Table 3.16,19, Table 4, Table 5.18 (Leányfalu).
}

Acta Archaeologica Academiae Scientiarum Hungaricae 71, 2020 
These biconical bowls constitute foreign forms among late Roman pottery. Although they do have Celtic antecedents, as do the techniques used for the smoothed-in decorations, they cannot be directly linked. The form reached the Danube from the east, probably from the Chernyakhov culture during the early- $5^{\text {th }}$ century. Here a local, Danubian variant developed, which is common in both late Roman and Germanic territories; even the $6^{\text {th }}$ century vessels are considered to have been derived from these Danubian archetypes. ${ }^{85}$ In Pannonia, Roman workshops continued to manufacture them even during the mid- $5^{\text {th }}$ century (e.g. at Szombathely). ${ }^{86}$

Jugs (13 pieces)

Most fragments belong to jugs. They are usually neck and shoulder fragments (Fig. 8). Rims have only been found for two large jugs. One of these is a jug with an everted rim and a wide mouth (from the daub layer). Its shoulder is slightly protruding, above and below it is a smoothed-in motif band (Fig. 9.4). Its fabric is soft, reddishgrey. Its belly shows traces of wheel. Its neck features a Murga-type motif. This motif is characteristic usually of jugs with a collared rim from the early $-5^{\text {th }}$ century onwards ${ }^{87}$ It is rare on pitchers with an everted rim. ${ }^{88}$ This type has a band handle, which starts at the rim; in this case, however it did not survive. The form is attested from the early Roman Period until the mid $-5^{\text {th }}$ century, mostly with vertical lines or bands on the neck, but there are also variants with smoothed-in decorations. ${ }^{89}$

The other jug rim is a funnel-like, everted rim. Starting at the rim is a band handle with a knob, imitating glass jugs (Fig. 9.3). Due to its fragmentary state, the motif is unclear (on its shoulder a lattice, above it a wavy line or a triangle filled with diagonal lines?). It was found during the removal of the stone debris. Jugs with funnel-like everted rims with similar handles comprise one of the most characteristic types of smoothed-in vessels at the turn of the $4^{\text {th }}$ and $5^{\text {th }}$ centuries and the first half of the $5^{\text {th }}$ century (their neck is ribbed). ${ }^{90}$

The rim of a ribbed fragment with a neck tapering upwards is missing. It could have had a funnel-like or a collared rim (Fig. 8.1). Based on its black smoothing, it belongs to the latest group. This vessel is the clearest proof that the material of the upper debris cannot be treated separately from the debris underneath, as some of the jug's fragments were found in the upper debris of room II/ $\mathrm{N}$ above and below the mortary floor. ${ }^{91}$

With the exception of the rim, the whole form of a large jug with lattice motifs survived (Fig. 6.3). Its surface, decorated with traces of wheel, and its fabric - similar to household pottery, thin-walled, hard-fired - place it in the latest group (although it was found in the lower debris). ${ }^{92}$ An almost intact vessel with a similar form and decoration was found in the daub debris of the north wing and the debris above the lower floor of room I west. ${ }^{93}$ The aforementioned form, which appears at the turn of the $4^{\text {th }}$ and $5^{\text {th }}$ centuries, is attested even during the mid- $5^{\text {th }}$

${ }^{85}$ PetrausKas 2011, Fig. 12 (not smoothed-in); At Barbarian settlements of the imperial period e.g. Csengersima-Petea they appear due to Germanic influence. See GindELE-IstVÁNOVITS 2009, 87 , Table 12.15 , Table 15.8 , Fig. $42-43\left(5^{\text {th }}-6^{\text {th }}\right.$ phase of pottery, $3^{\text {rd }}-$ $4^{\text {th }}$ century: not smoothed-in!); OPREANU 2013, Pl. III; SoÓS-BÁRÁNYKÖHLER-Pusztai 2017, 62 (Hernádvécse, Hun period); Horváth 2011a, 631-633, Fig. 19 (with further references); MASEK 2011, 260261; BoCsi 2011, 112-113, Fig. 1.1 (Zamárdi); TEJRAL 1985, 130 132, Fig. 24; Friesinger-KERCHLER 1981, 262-263 (Ternitz); QUAST 2008, 278, Fig. 12.1,3 (Runde Berg, pottery group 6.); HeGEwISCH 2011, Fig. 23-24 (Germania, $4^{\text {th }}-6^{\text {th }}$ century: not smoothed-in).

${ }^{86}$ OtTOMÁnYI-SOSZTARITs 1998, 160-163, Table IV.6, Table. V.1-5, Table. VI.6-9, Map I (map of its spread)

${ }^{87}$ Murga-type motif on the neck of a jug with collared rim from the west wing (OtTOMÁNYI 2015a, 42, Fig. 14.10); TeJRAl 1985, Fig. 14.2-3, Fig. 15.1; TeJRAL 1988, Fig. 27.12 (Kistokaj), Fig. 29.6 (Murga), Fig. 44.4 (Smolín); Bierbauer 2015, Fig. 29.11 (Košice); MAseK 2013, Fig. 5.1 (Körösladány); MASEK 2018, 139-140 (at Rákóczifalva in horizon 1 of the settlement: on the jugs' shoulder, in horizon 3: on the jugs' neck).

${ }^{88}$ In the Migration Period phase $1 \mathrm{~B}$ of the Gyor fort there is a similarly-decorated neck of a mug or jug with an everted rim (Tomka 2004, Table 5.3); Dunabogdány, fort reduction (OTTOMÁNYI 1999, Pl. VI.7); TejRal 1988, Fig. 46.5 (Levice); Antecedents of the pattern appear in Pannonia during the early Roman Period as well as in $2^{\text {nd }}-3^{\text {rd }}$ century Sarmatian pottery (OTTOMÁNYI 1982, 80; VADAY 1989, 141-143; MASEK 2013, 245).

${ }^{89}$ OtTOMÁnyi 1982, Table VI. 4-4a (Szentendre, Bia, Intercisa, Fenékpuszta, Nagykanizsa, Pécs); ОттомánYi 1999, 346, Pl. VI.8; Tомка 2004, Table. 4.6, Table 8.3 (Győr, Migration Period phase $1 \mathrm{~B}$ and phase 3 of the fort).

${ }^{90}$ OtTOMÁNYI 1982, Table VII-VIII. Type 9a-d (usually vertical lines on the neck, lattice pattern on the shoulder and belly); OtTOMÁNYI-SoszTARITS 1998, 166, Table VII.7 (mid- $5^{\text {th }}$ century); FRIESINGER-KERCHLER 1981, Fig. 24-25,57; STADLER et al. 2008, 160 (Mödling: prior to 405-420); TeJRAL 1988, Fig. 14.6, Fig. 18.19, Fig. 24.6. etc. (horizon D1-D2).

${ }^{91} \mathrm{~A}$ jug neck from room III/S has the same decoration (wavy line under vertical band). See OtTomÁnYi 2015a, Fig. 14.5; Among Keszthely-Fenékpuszta pottery, fragments of jugs with a collared rim have a similar decoration (HoRvÁTH 2011a, 633-634, Fig. 16. 9-11).

${ }^{92}$ Large jug with a body ribbed with the same traces of wheel e.g. in the south wing, household and glazed pottery variants (OtTOMÁnYi 2015a, Fig. 9.10 (household pottery), Fig. 12.1 (glazed); From the daub debris of room I/N without rim: OTTOMÁNYI 2018c, 125, Fig. 3.5 (lattice motif), Fig. 3.4 (traces of wheel).

${ }^{93}$ OtтománYi 2015b, 721, Fig. 12.6 (fabric gritty, hardfired, but with smoothing on the body and no traces of wheel). Another example of how the materials from the various layers fit together (zs/32-33. + 53. See OtTományi 2012, Table 1). 
century. ${ }^{94}$ On these latest items the smoothed-in decorations are combined with plastic ornaments; they are found mostly in later features dug into the Roman layers. ${ }^{95}$

The majority of jugs have a band handle with one or two segmentation, decorated with vertical smoothing.

Forms securely identified as mugs or pots do not have smoothed-in decorations. There are two small fragments, in the case of which it is impossible to say whether they belonged to a jug or a pot (with vertical and diagonal smoothed-in lines respectively). The diameter of the shoulder fragment number 5 of Fig. 9, too, cannot be measured. I included it among the jugs, but it could have been a pot as well.

\subsubsection{Layers and groups}

Smoothed-in decoration itself constitutes a new type of ornament on late Roman pottery. In its earliest group characteristic are the unframed horizontal, vertical or wavy smoothed-in ornaments (lattice pattern is rare at this stage).They are grey, well-levigated. ${ }^{96}$ Based on their form and pattern perhaps the two bowls smoothed-in on the inside, although both are from the topmost, stony debris and other, later, smoothed-in fragments were also found alongside them. Below the vertical smoothed-in decoration of the neck fragments there could have been all kinds of other patterns. Hence they cannot be placed in a group according to this. The same applies to two jug shoulder fragments with diagonal lines. One of these (Fig. 8.2) is, based on the layer (from the excavation of the upper floor), perhaps earlier than the other vessels from the destruction debris. Their fabric, however, was hard-fired, and the fabric of one is gritty (2013.14.9.6.). Based on the above, we can place perhaps two or three fragments into this Group 1, but not with certainty. At Gizellamajor they can be dated to the Valentinian period - final third of the $4^{\text {th }}$ century. ${ }^{97}$

In Group 2 of smoothed-in pottery belong the vessels with framed ornaments or ornaments organised into bands. There are still many Roman forms (jugs, mugs), but new types, too, already appear (jug with collared rim, biconical bowl). High quality, grey; but there are many hard-fired wares among them. They date to the turn of the $4^{\text {th }}$ and $5^{\text {th }}$ centuries and the first third of the $5^{\text {th }}$ century. ${ }^{98}$ Most fragments can be placed in this group. They were found in the layer with the stone mortar, above the mortary layer, as well as the upper stone and daub debris.

Based on their design, the latest (Group 3) are those smoothed-in vessels with a shiny black smoothed-in decoration (1 piece: Fig. 8.1), or with a gritty fabric (1 wall fragment), and perhaps a thin-walled vessel fired 'ringing' hard (1 piece: Fig. 6.3). The body of the third vessel is decorated with traces of wheel, just like the belly of another soft-fired jug, decorated with a Murga-type motif (Fig. 9.4). The traces of wheel were emphasised in both cases by horizontal smoothing. The four abovementioned late fragments belonged to jugs. Based on its form, a biconical bowl with a strongly carinated belly also belongs here (Fig. 7.9). In terms of layers, the fragments of the jug with black smoothing were found in room IIb/N below and above the mortary floor as well as in the upper debris; it therefore comes from either the infill or the destruction debris after the room was no longer used (its fragment from room III/N is without a layer). The jug with lattice pattern, however, comes from the lower debris (western foreground of the northern gate, so possibly also from room IIb/N and not room III/N). The biconical bowl and the jug with the Murga-type motif come from the upper daub layer. The above indicates that, based on layers, the smoothed-in fragments in room III/N cannot be differentiated. "Murga pottery" with shiny, black smoothing is usually dated to between the first half and the final third of the $5^{\text {th }}$ century in the Middle Danube region (its heyday is

\footnotetext{
${ }^{94}$ In Leányfalu with a lattice pattern and traces of wheel, without a rim (OTTOMÁNYi 1991, Table 39.1).

${ }^{95}$ E.g. in Ács-Vaspuszta with incised wavy line, in a $5^{\text {th }}$ century refuse pit (OTTOMÁNYI 1989, Fig. 122.19);

${ }^{96}$ For more details on the classification of pottery see OtTomÁnYi 1991, 36-37; ОтTомÁNyi 2009, 430-434; То́тн 2005, $380-385$. The classification of vessels into these groups is not always unequivocal. Sometimes at the same site vessels from all three groups are found.

${ }^{97}$ То́тн 2005, 380: dates the first group to the middle third of the $4^{\text {th }}$ century onwards, connecting it with the Carpi. The date when this pottery type appeared likely differed by regions, e.g. at Tokod, near Visegrád, smoothed-in pottery (2 pieces) was found in the topmost debris layer of the pottery workshop's buildings, by the
}

fort. It does not yet appear in either the foundations (under Constantius II) or the burnt layer (Valentinian period), even though these contain large numbers of glazed and gritty household pottery (KELEMEN 2012, 82).

${ }^{98}$ According to Endre Tóth this second group dates to after 430 and was spread in the borderlands by our eastern neighbours, the Sarmatians (TóTH 2005, 380-385). But then it cannot be explained why they keep on being produced at Roman period Limes forts, which in Valeria were destroyed for the most part in the 430s. This group is often referred to as "Föderatenkeramik", which is dated by Austrian researchers to the final third of the $4^{\text {th }}$ century-first half of the $5^{\text {th }}$ century; this was modified by new C14 analyses to prior to 390/405410/420 (StAdLER et al. 2008, 159-160, Fig. 2-3, Table 3: Unterlanzendorf, Mödling). 

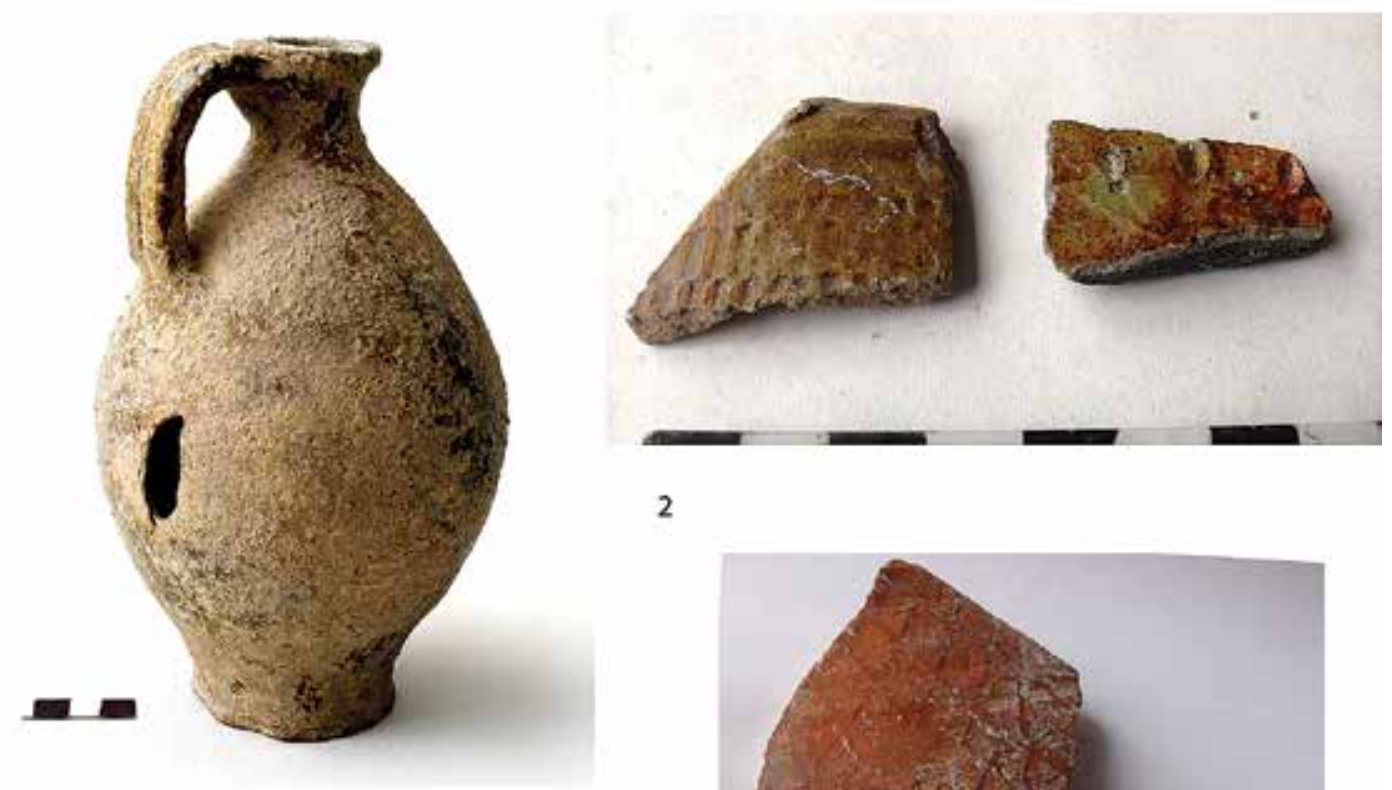

1

2
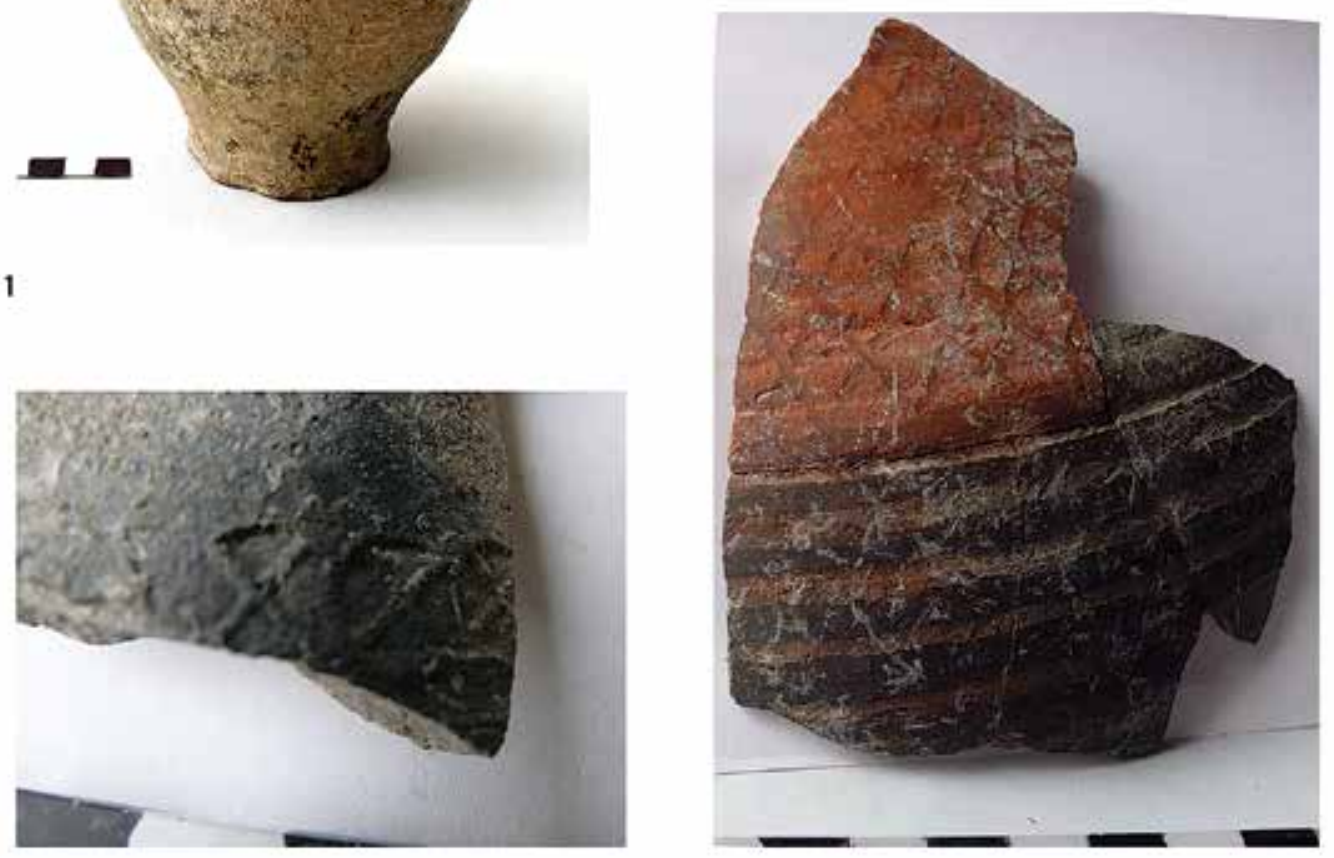

3

4

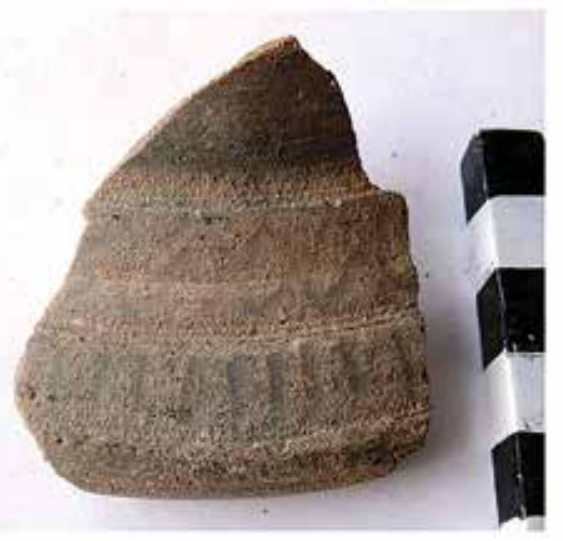

5

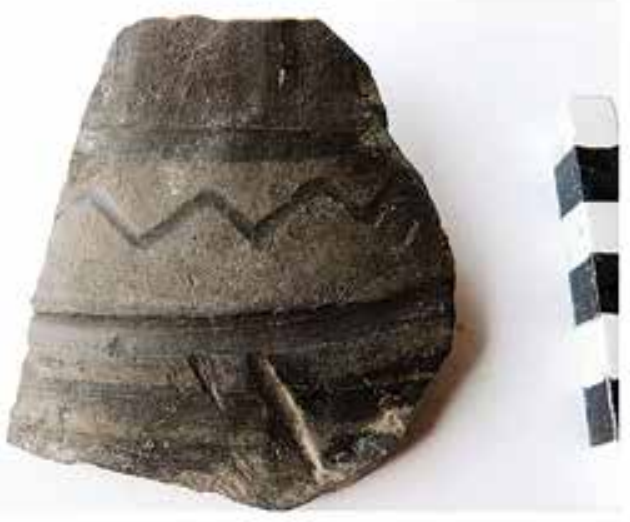

6

Fig. 10. Glazed (1-3) and smoothed-in pottery (4-6). 1: 2013.14.7.1.; 2: 2013.14.1.10-11.; 3: 2013.14.1.9.; 4: 2013.14.22.5.; 5: 2013.14.6.52.; 6: 2013.14.23.1.

Acta Archaeologica Academiae Scientiarum Hungaricae 71, 2020 
the middle third of the century) ${ }^{99}$ Vessels of Group 2 and 3, i.e. grey vessels and pottery fired black, can often be found side by side on the same site, sometimes even the forms are similar. ${ }^{100}$

The varied motifs and forms of the smoothed-in vessels of room III/N indicate that most were in use before the actual Hun period, since the preponderance of biconical bowls with lattice pattern, characteristic of the mid- $5^{\text {th }}$ century, cannot yet be observed here. ${ }^{101}$

If smoothed-in vessels are missing from a layer that is likely a coincidence, since the whole room itself was created during the remodelling in the Valentinian period. ${ }^{102}$ There is no such material connected with the layer dating to the remodelling. There was no smoothed-in pottery either next to the glazed jar and the jewellery found in the lower heating flue; the bone comb found there, however, dates the layer to the turn of the $4^{\text {th }}$ and $5^{\text {th }}$ centuries. Similarly-aged might be the - in terms of stratigraphy - earliest smoothed-in jug fragment from the excavation of the (upper?) floor (Fig. 8.2) and the layer with the stone mortar (Fig. 8.3). The vessel from the lower debris, as we have seen above, based on its fabric and design can be placed in the latest group. The other vessels are later, from the upper daub layer and the mixed debris or infill. Along with them appears glazed pottery in all layers; hence, based on this either, it is not possible to distinguish a later group. ${ }^{103}$

The use of pottery with smoothed-in decoration indicates a foreign, eastern influence on late Roman pottery. Its connection with a specific ethnic group and its closer dating is still debated. Based on its forms, motifs, and design it can be divided into at least two, but more likely three groups. It came to Pannonia in several waves and through the influence of several ethnic groups, and there, blending with local forms, it was also produced by local workshops from the Valentinian period until the mid- $5^{\text {th }}$ century. ${ }^{104}$

\subsection{Pottery with a smoothed surface}

Smoothing the surface of vessels - following early Roman precedents - reappears during the early $-4^{\text {th }}$ century in Pannonia. Initially, it is used on traditional Roman forms, then at the turn of the $4^{\text {th }}$ and $5^{\text {th }}$ centuries new types appear, sometimes with darker, shiny, black smoothing. In room III/N altogether 124 pieces of pottery with a smoothed surface were found, of which a quarter (31 pieces) could be connected with a vessel form.

\subsubsection{Smoothing: method, colour and fabric}

The smoothing is usually shiny, matches the colour of the fabric. Only 14 fragments have a darker smoothing, of these four are shiny, black (Fig. 7.4. and 6; 2013.14.5.12.: lower half of a biconical bowl; 2013.14.15.8.: outcurved rim). The latter are the latest based on both the design and the biconical vessel form (bowl form with a conical base).

There is contiguous smoothing, covering the whole surface on half of the fragments (c. 60 pieces). The other half is horizontally smoothed ( 36 pieces), on which the bands (13 pieces) or lines ( 2 pieces) sometimes sepa-

${ }^{99}$ TeJRAL 1988, 267-268, 280; GRÜNEWALD 1979, 78-81, Fabrikat C; HoRvÁTH 2011a, 633; MASEK 2011, 267, Table 2-4 (vessels reduction fired black on the outside, but with an oxidated core represent a new, foreign technology, which are also used on local, Sarmatian forms); MASEK 2013, 245-247, Fig. 2.: the so-called Murga type jug appears as a foreign form in period C3/D1 and is attested until the early- $6^{\text {th }}$ century on the Great Hungarian Plain (not only with black, shiny smoothed-in decoration, but as a grey-coloured variant as well).

${ }^{100}$ The latest vessels - in terms of technique - of room III/ $\mathrm{N}$ may have belonged to the previous Group 2 in terms of their period, since on one of the fragments of the jug with shiny, black smoothing the smoothed-in decoration was not fired black, just darker. The gritty and ribbed surface also appears on household pottery at the turn of the $4^{\text {th }}$ and $5^{\text {th }}$ centuries. The jug with a neck decorated with a Murga-type motif is a traditional, Roman form. Along with the sharply carinated biconical bowl, in the same daub layer, was also a more spherical biconical bowl with diagonal lines. In this case both may belong to the latest period.

${ }^{101}$ Mid- $5^{\text {th }}$ century pottery workshop: Szombathely (OTTOMÁNYI-SOSZTARITS 1998 , Table V-VI); late- $5^{\text {th }}$ century pottery workshop: Ternitz (FRIESINGER-KERCHLER 1981, Fig. 33-41).

${ }^{102}$ There are no smoothed-in vessels in pottery groups Ia-b and IIb, which, however belonged to layers $2 / 3-4$ of the fort (see Table 1). If there is no smoothed-in pottery in groups IIa or IIc there is a late smoothed vessel (2013.14.15., and 19.).

${ }^{103}$ Smoothed-in pottery appears without glazed vessels until the $6^{\text {th }}$ century in already abandoned Roman forts and Barbarian settlements e.g. Arrabona phase 2-3, Szabadbattyán, Ordacsehi, Zamárdi (TomKA 2004; Bocsi 2011).

${ }^{104}$ For more details see OTTOMÁNYI 2015a, 39-46; HoRVÁth 2011a, 625-630; CoNRAD 2007, 234-236 (Iatrus: blending of Roman, Germanic, Sarmatian and Dacian forms); Tóтн 2005, 375-382; GASSNER 2000, 236-244. 


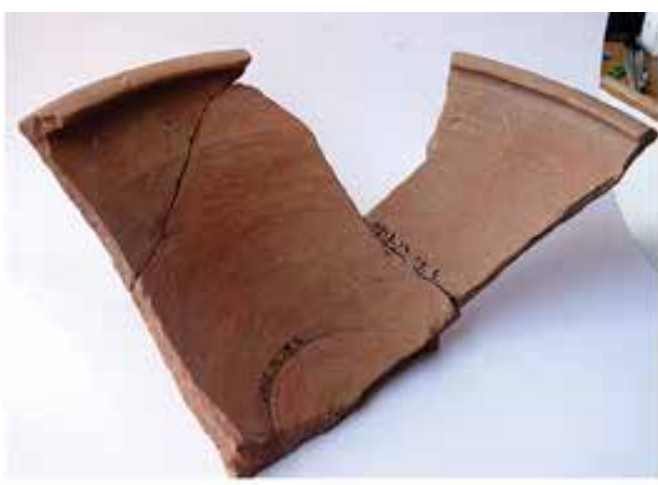

1

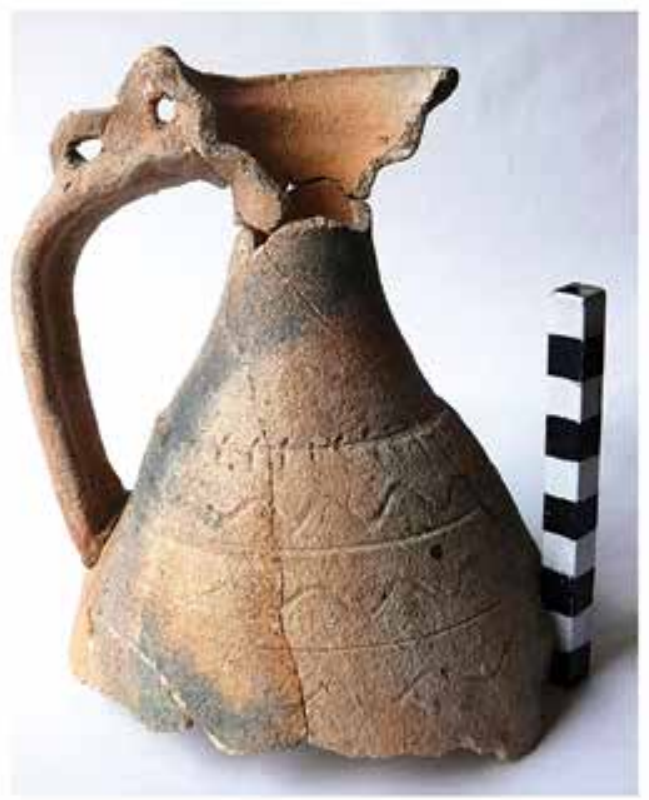

3

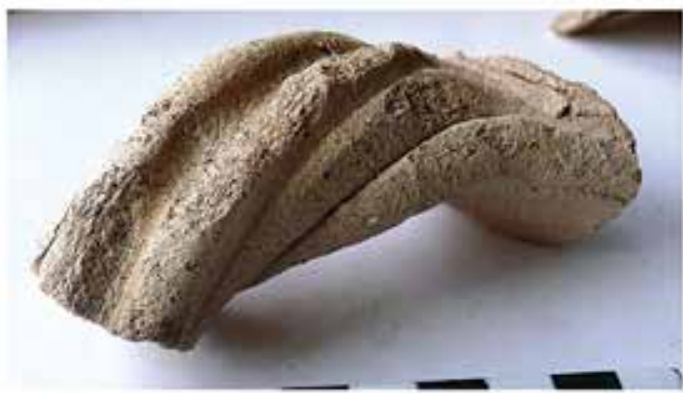

5

6

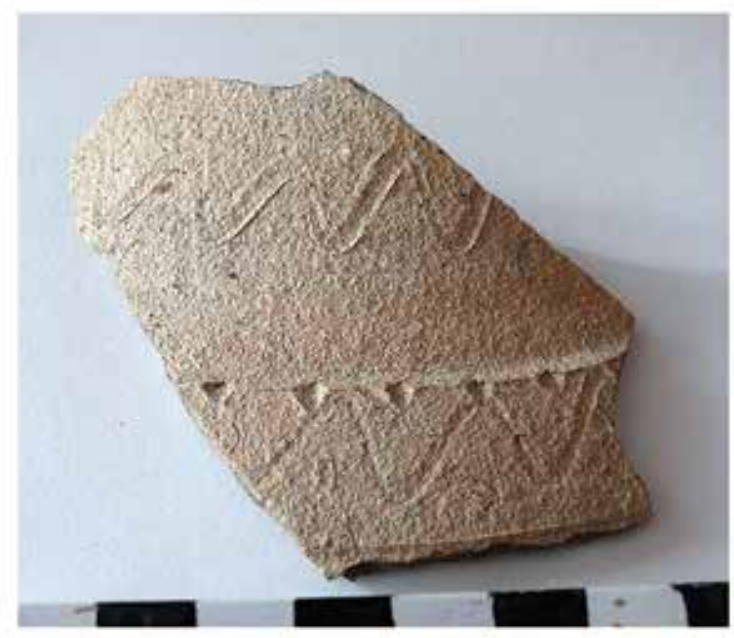

4

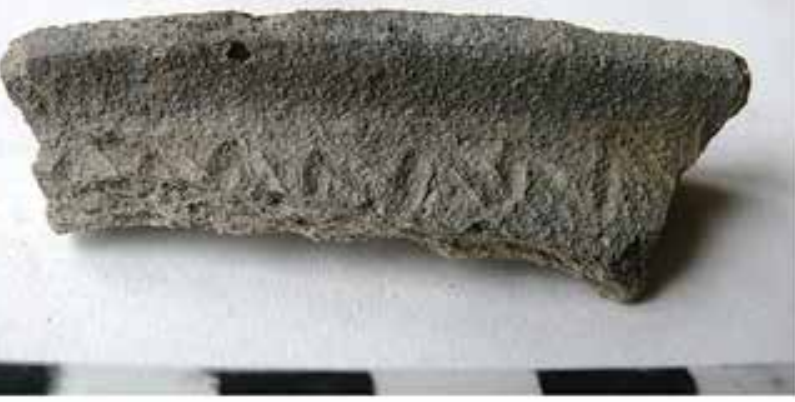


rate. Vertical smoothing appears on one jug neck (2018.1.13.21.). On the rest (30 pieces) there are just traces of smoothing. ${ }^{105}$ Mostly there is a connection between the method of smoothing and the vessel form. Bowls are usually smoothed horizontally on the outside. In the case of jugs the neck is smoothed vertically, the belly and lower half horizontally or contiguously. Some of the latter could even belong to smoothed-in vessels, where the smoothed-in motif broke off.

Most are well-levigated, medium-hard fired. Few are hard-fired (29 pieces, 23.4\%), of these even fewer are fragments of a granular (4 pieces), or gritty (4 pieces) fabric. There are two soft-fired vessels, and there is also one with a very micaceous fabric. Two smoothed pot fragments were made by slow-wheel (2013.14.1.47. and 14.19.29.), while one foot was hand-made (2013.14.2.44.).

Their colour is usually grey (101 pieces, $82 \%)$, of these there a few light (17 pieces) and dark grey (20 pieces) fragments. In some cases one side was fired light, the other dark ( 9 pieces). The rest are brownish-grey, reddish-grey, or fired reddish-brown on the outside and grey on the inside etc. Few are brick-coloured ( 3 pieces), or brown (5 pieces), or brownish-red (8 pieces).

\subsubsection{Forms}

\section{Bowl (13 pieces) $)^{106}$}

There were bowls with an inverted rim (4 pieces), bowls with a segmented upper part, with a carinated shoulder and a conical base ( 3 pieces) and biconical bowls ( 5 pieces) made with a smoothed surface. On bowls with a horizontal rim in one case do we find smoothed bands on the outside; the inside of this bowl is glazed (Fig. 4.4). Bowls glazed on the inside, smoothed on the outside, with an inverted or horizontal rim are also found elsewhere in the Gizellamajor fort. ${ }^{107}$

The rim of the bowls with an inverted rim is swollen, straight cut or sharply undercut. Their lower half is mostly conical. The rims of two are grooved. The piercing under the rim is probably due to later repair (wiring) (Fig. 7.1). Among cover bowls the brick-coloured bowl from the daub debris, with two encircling grooves outside under the rim represents a rare form (Fig. 7.2; Fig. 11.1). ${ }^{108}$ The bowl form is attested during the four centuries of the Roman Period. Its rim, form and design change during the various phases. ${ }^{109}$ In Visegrád, it can be found in all wings in the fort, with different rims, with both deeper and flatter variants. ${ }^{110}$

The bowl type with a segmented upper part (swollen rim) and carinated shoulder appears in both glazed and household pottery during the late Roman Period. One fragment is smoothed shiny, black on the outside (lighter smoothing on the inside). The other is hard-fired, with a gravelly fabric, reminiscent of household pottery (Fig. 7.4-5). The third fragment was pierced below the rim (2013.14.1.30.). All come from the upper stony brown layer. One of them matches the material of the infill above the upper floor in room II/N. Similar forms, both smaller and larger, were also found in room $\mathrm{I} / \mathrm{N}$ and the west and south wings, in layers $2-4 .{ }^{111} \mathrm{In}$ the Danube bend it appears in several watch-

\begin{abstract}
${ }^{105}$ In recent years Zsófia Masek has been studying the polished surfaces and ornaments on Sarmatian smoothed and smoothedin pottery created by various pottery techniques (polish by e.g. lathe, wooden knife, gravel etc.). Horizontal smoothing was done usually with a potter's wheel, while vertical smoothing and smoothed-in decoration was always by hand, without a wheel (MASEK 2018, 61-72).

${ }^{106}$ There are two other bowls horizontally smoothed-in on the outside and with dense vertical smoothed-in decoration on the inside (with inverted rim and horizontal rim), which I describe in the section on smoothed-in vessels. For more on the bowl glazed on the inside and smoothed on the outside see the section on glazed pottery.

${ }^{107}$ Three in the NW tower, of these two have an inverted rim (ОттомÁnYi 2018b, 135, Fig. 3.7, Fig. 4.4-5). For the analogies of the bowls with a horizontal rim see the section on glazed bowls.
\end{abstract}

\begin{abstract}
${ }^{108}$ A similar, but smaller bowl was found in room III/S (OtTományi 2015a, Fig. 13.3); Carnuntum: GrÜnEwALd 1979, 75, Table 75.1-2.

${ }^{109}$ Produced with a smoothed surface at the turn of the $4^{\text {th }}$ and $5^{\text {th }}$ centuries e.g. at the Mautern kiln (FRIESINGER-KERCHLER 1981, Fig. 2.8-9, Fig. 3.4,13. Same kiln, glazed variant: Fig. 7.2.); Leányfalu workshop: OTTOMÁNYI 1991, Table 1.2, Table 2.9a (smoothed), Table 1.5,6,7 (glazed), Table 1.4,5a, Table 2.9,10 (household pottery); Dunabogdány, fort limitation material: OтTомÁNYi 1999, 343, Pl. V.1-3; Horváth 2016, 64, Fig. 8; JelinČIĆ 2015 , Table 156 ( $1^{\text {st }}-4^{\text {th }}$ century). ${ }^{110}$ Otтомányi 2015a, 36-37, Fig. 4.1,3, Fig. 8.1, Fig. 13.1-3; OтTOMÁNYi 2015b, 718, Fig. 11.2.

${ }^{111}$ OTTOMÁNYi 2018a, 109, Table 7.2; OtTOMÁNYi 2018c, 124, Fig. 3.1; Оттоми́Nyi 2015b, Fig. 11.2 (above the lower floor); OTTOMÁnyi 2015a, 37, Fig. 4.2,4 (from the upper debris layer, with further analogies).
\end{abstract}

Acta Archaeologica Academiae Scientiarum Hungaricae 71, 2020 
towers and forts. ${ }^{112}$ It was one of the main bowl forms produced by the Mautern kiln at the turn of the $4^{\text {th }}$ and $5^{\text {th }}$ centuries. $^{113}$

Biconical bowl: 5 pieces, of these three are smoothed black, shiny. These include a biconical vessel with tall, ribbed neck (Fig. 7.6), ${ }^{114}$ as well as a base fragment (2013.14.5.12.). The latter's reddish-brown colour, darkgrey on the outside, and its fabric, hard-fired, resemble fragment 2013.14.4.21. (it is possible that the materials from the two layers belong together: above the clayey brown level and the dark brown above the clay surface). An outcurved rim fragment, also smoothed shiny and black, probably also belongs to such a type (2013.14.15.8.). This biconical form, therefore, based on both its design and non-Roman form, can be placed in the latest, $5^{\text {th }}$ century pottery group. Two further, flatter biconical bowl fragments with less everted rims were smoothed horizontally and medium-hard fired (Fig. 7.7; 2013.14.19.12.). ${ }^{115}$ In terms of layers, they come from the topmost daub, mortary debris, from the infill above the upper floor, though one piece was also found in the daub debris above the lower floor. The biconical form is attested in all wings in the Gizellamajor fort, often with the same surface, smoothed black and shiny. ${ }^{116}$

\section{Jug}

Around 13 pieces can be placed in the group. Two rims, jug necks (Fig. 9.1) and handles (5 pieces). The everted small rims may be connected with pitchers with a wider mouth or jugs with a narrower neck, though they might have also belonged to mugs (2013.14.20.19.; 2018.1.13.21.). The smoothing on the neck is usually vertical, while on belly fragments it is horizontal. On the lower half of the smoothed-in jugs, too, we can observe horizontal smoothing (e.g. 2013.14.1.40. +41.). On the outside, the band handles were smoothed vertically or contiguously; one of them belonged to a large jug (2013.14.1.6.). ${ }^{117}$

The majority of wall (73 pieces) and foot (13 pieces) fragments smoothed externally, too, likely belonged to jugs, but some may have been parts of mugs or larger pots. The gritty hard-fired wall fragments (4 pieces) belonged rather to mugs.

\section{Mug/pot}

There is only one rim fragment, which, given its characteristic protruding shoulder, likely belonged to the so-called Leányfalu type (Fig. 9.6). ${ }^{118}$ This form is characteristic of household pottery, but rarely it also occurs on other designs (smoothed, glazed). ${ }^{119}$ The few thicker-walled wall and foot fragments (c. 5 pieces), too, likely were from pots. The two fragments made with a slow-wheel (one is a foot fragment) and the hand-made foot fragment can in all certainty be connected with pots.

Storage vessel

One wall and one foot fragment belong here; they are light grey and light brown. Storage vessels with a smoothed surface were typical in the $1^{\text {st }}$ and $2^{\text {nd }}$ centuries; they came once again to the fore in the $4^{\text {th }}$ century. The Gizellamajor pieces are made of a well-levigated, medium-hard fired fabric, and have a contiguously smoothed surface.

\begin{abstract}
${ }^{112}$ Leányfalu: OTTOMÁNYi 1991, Table 2.12, Table 3.1415; OtTOMÁNYi 2004, Table 1.4-8 (Budakalász-Luppacsárda); OTtománYi 1999, 343-344, PL. V.4-5 (Dunabogdány, fort reduction).

${ }^{113}$ FriesingER-KERCHLER 1981, 261, Fig. 2.2-7, Fig. 3.612, Fig. 45.3, Fig. 57 (it appears around 375 and continues to be used until the end of the $5^{\text {th }}$ century); The main bowl type in the latest period of the Mautern fort: GASSNER 2000, 217, Fig. 185, 197; GROHSEDLMAYer 2002, 218-222, Fig. 140-141; GroH-SedLMAYER 2013, Fig. 8 (dated to the $4^{\text {th }}$ century); UBL 1986, Fig. 20 (Klosterneuburg); GRÜNEWALD 1979, 76, Table. 72-73 (Carnuntum).

${ }^{114}$ Its form resembles late Celtic vessels, but this is not unique among late Roman smoothed-in vessels. Its $4^{\text {th }}$ century analogies can be found among the vessels of the MarosszentannaChernyakhov culture (BOTÁr 2011, Table 3.1-2); this variant with a ribbed neck is also common in Moravian territory (with smoothed-in
\end{abstract}

decoration): TeJRAL 1985, Fig. 17.7-8 (first half/middle of the $5^{\text {th }}$ century), Fig. $27.1,9$ (turn of $5^{\text {th }}$ and $6^{\text {th }}$ centuries).

${ }^{115}$ OTTOMÁNYi 2004, 275, Table II.1 (Budakalász-Luppacsárda); OtTOMÁNYI-SoszTARITs 1998, Table VI.7 (Szombathely: smoothed with horizontal bands; from a mid- $5^{\text {th }}$ century kiln); SoósBÁRÁNY-KÖHLER-PUSZTAI 2017, Pl. I.1 (Hernádvécse, Hun period)

${ }^{116}$ West wing (OTTOMÁNYi 2015b, Fig. 11. 3); South wing (OtTománYi 2015a, Fig. 8.2, Fig. 13.5.); room I/N: OtTOMÁNYI 2018c, 124 (3 pieces from the upper, stony debris).

${ }^{117}$ In the south wing there are many large smoothed jugs with one or two handles (OTTOMÁNYI 2015a, 38, Fig. 13.8); west wing (OtTomÁNYi 2015b, Fig. 13.1) etc.

${ }^{118}$ Its form is uncertain. It may have been the rim of a biconical bowl, but it is not smoothed on the inside. It more likely belonged to a Leányfalu type mug.

${ }^{119}$ OtTományi 1991, 23, Table 31.61b (Leányfalu). 


\subsubsection{The latest group (turn of the $4^{\text {th }}$ and $5^{\text {th }}$ centuries-first half of the $5^{\text {th }}$ century)}

Around 7 fragments can be placed in this group. They come from above the upper floor and from the stony, daub debris. On four bowls with a sharp shoulder carination and a conical base we can observe shiny, black smoothing. One has a straight, segmented rim (Fig. 7.4), the other three are biconical bowl fragment (two outcurved rims: Fig. 7.6; 2013.14.15.8., and a lower part: 2013.14.5.12.).

Based on their forms, two other biconical bowl fragments may have belonged in this group, although the smoothing on them is darker than their fabric's colour (Fig. 7.7; 2013.14.19.12.). The Leányfalu type pot, too, represents a new form from the final third of the $4^{\text {th }}$ century $(2013.14 .19 .11$.$) .$

Fragments with a gravelly (4 pieces), gritty (4 pieces) and hard-fired (c. 20 pieces) fabric, too, may have survived into the $5^{\text {th }}$ century. Among them is a bowl with a conical base (Fig. 7.5).

\subsection{Household pottery}

Most common in all rooms of the fort are the household pottery used for everyday baking and cooking. They could also be used as serving vessels, replacing the previously prevalent neutral-coloured, well-levigated bowls and jugs. They can be found in all layers. In room III/N 730 pieces were found.

\subsubsection{Design (fabric, colour)}

Their fabric is usually hard-fired. $70 \%$ are gritty (504 pieces), more rarely well-levigated, mica-tempered (147 pieces) or gravel-tempered (48 pieces). Only 31 pieces are medium-hard fired. Among the latter there are around 10 fragments with a smooth (but not smoothened) surface.

Half the fragments are grey (363 pieces), light or dark grey, often fired in layers. Fragments can also be greyish-brown (24 pieces), reddish-grey (56 pieces), or just red (63 pieces), or rarely brown (8 pieces). ${ }^{120}$ The latest group is the yellowish-white, whitish-grey, sometimes pinkish-white pottery, always made of a gritty fabric, fired 'ringing' hard (201 pieces, 27\%).

\subsubsection{Forms}

$74 \%$ of the fragments are wall and foot fragments (524 pieces, 70 of which are feet), which cannot be connected with a precise form. I grouped the narrow necks and handles with the jugs, pieces with a sharply carinated shoulder with the bowls, wall fragments with a protruding shoulder with the Leányfalu type mugs/pots. Only for a quarter of the fragments could a specific vessel form be ascertained. There are also a few conical and biconical spindle whorls from the daub layer (Fig. 12.9-11). ${ }^{121}$

Bowl (c. 20 pieces)

Bowl with an inverted rim: this is the most common bowl type during the four centuries of the Roman Period, with changing rims and walls. It occurs as glazed, smoothed as well as household pottery in the $4^{\text {th }}$ century. ${ }^{122}$ Its rim on the outside may be punctuated by one or two lines (Fig. 12.1). ${ }^{123}$ Its latest variant is the covering

\footnotetext{
${ }^{120} \mathrm{On}$ vessels produced by two-phase firing the surface is grey, the inside is fired red (Soós-BÁRÁNY-KöHLER-PusZTAI 2017, 62; MASEK 2011, 258-263).

${ }^{121}$ Forms used for a long time, e.g. OTTOMÁNYI 2008, 175, Fig. 17.8 (Biatorbágy, Hun period settlement).

${ }^{122}$ GRÜNEWALD 1979, 64, Table 58.3-13 (late- $3^{\text {rd }}$ century$4^{\text {th }}$ century); OTTOMÁNYI 1989, Fig. 113-114 (Constantinian dynastyearly-5 $5^{\text {th }}$ century); OTTOMÁNYI 1999, 352, Pl. VIII.4-6 (Dunabogdány); HoRVÁTH 2011a, 620-621, Fig. 7.11 (Keszthely-Fenékpuszta); LÁNYI 1981, 78, Type XXVII, Fig. 14.1-6 (Tokod); the form survives until
}

the mid- $5^{\text {th }}$ century, e.g. Ordacsehi-Csereföld (Bocsi-GallinaSomogyi 2016, 103, Table 2. 3); CiglenečKi 1984, Fig. 1.5-8, Fig. 6.2-3 (Gradec bei Prapetno, Tinje, $4^{\text {th }}-6^{\text {th }}$ century); JeLINČIĆ 2015 , Table $153,156\left(1^{\text {st }}-4^{\text {th }}\right.$ century $)$.

${ }^{123}$ This bowl was found in the narrow area between room III/N and the west wing, in the courtyard. It may also have belonged to the material of III/N's external furnace. The other pieces of pottery found here were published together with those from the western half of the courtyard, but this drawing was left out from that article (ОтTOMÁNYI 2018a). 


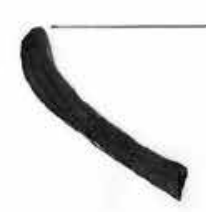

1

2

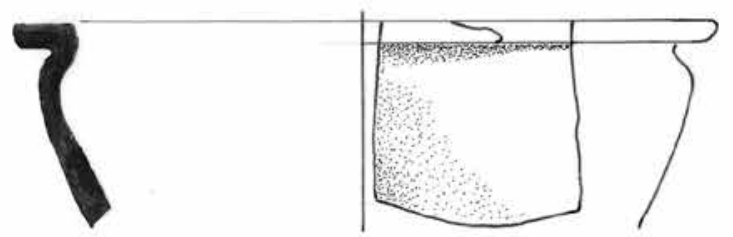

2013.14.20.16.

3

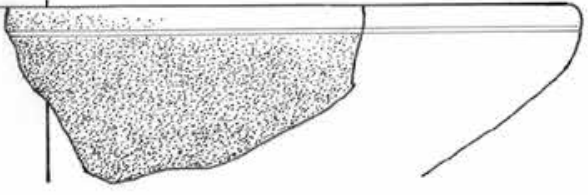

2013.14.10.3.

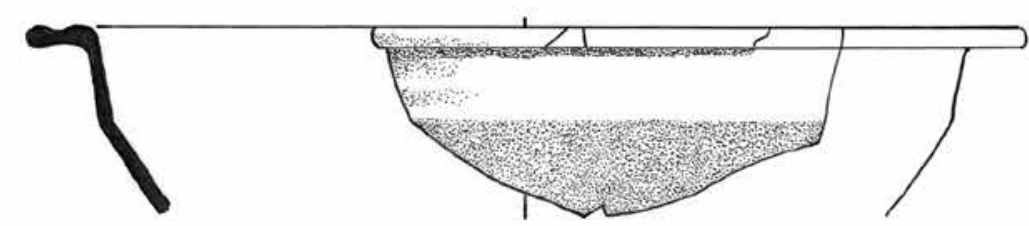

2013.14.5.7.

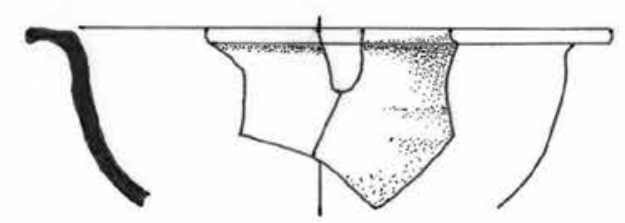

2018.1.13.13.

4

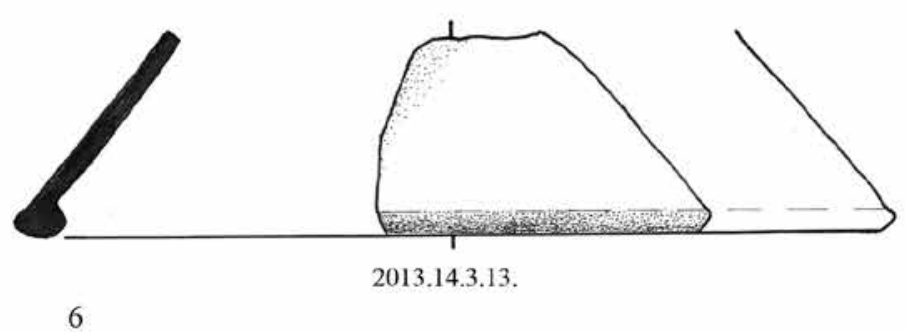

5

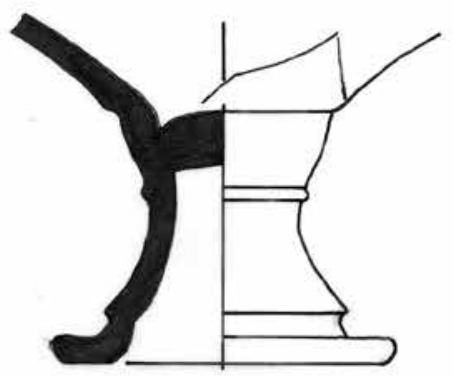

2013.14.6.50.

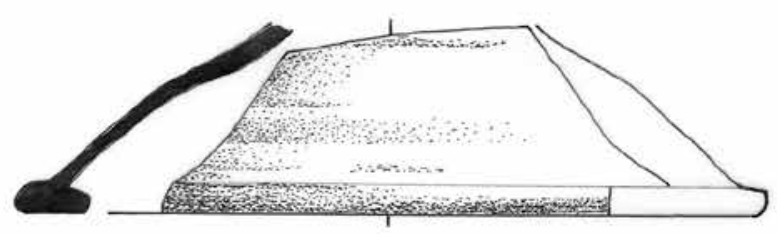

2013.14.6.93.

7

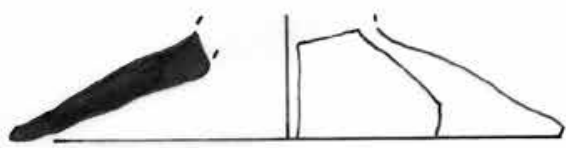

2013.14.13.4.

10

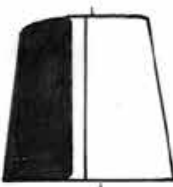

2013.14.6.145.

9

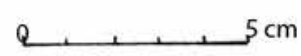

8

Fig. 12. Household pottery bowls (1-5), lids (6-8) and spindle whorls (9-11)

Acta Archaeologica Academiae Scientiarum Hungaricae 71, 2020 


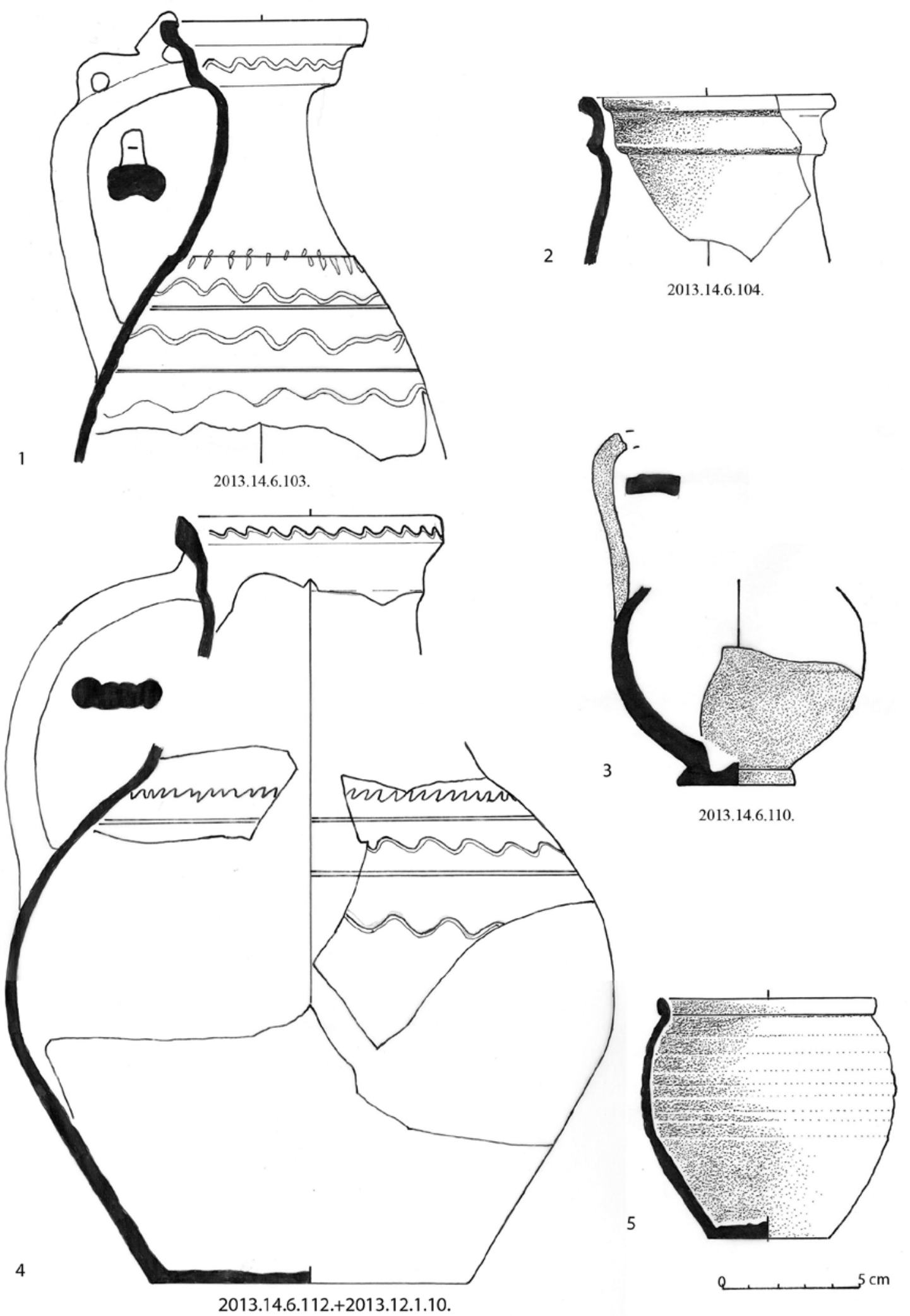

Fig. 13. Household pottery jugs and mug (first half of the $5^{\text {th }}$ century)

Acta Archaeologica Academiae Scientiarum Hungaricae 71, 2020 


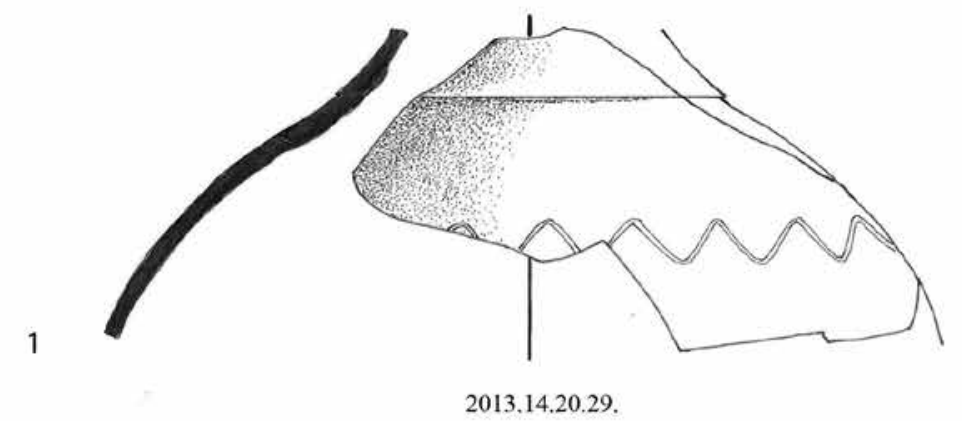

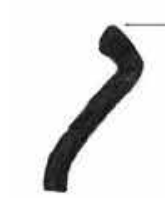

2

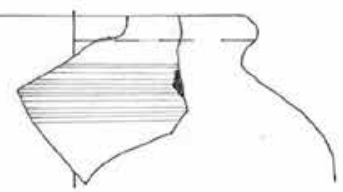

2018.1.13.17.

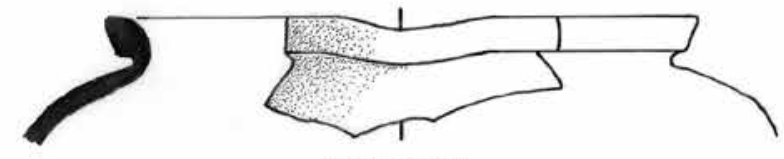

2013.14.12.12.

3

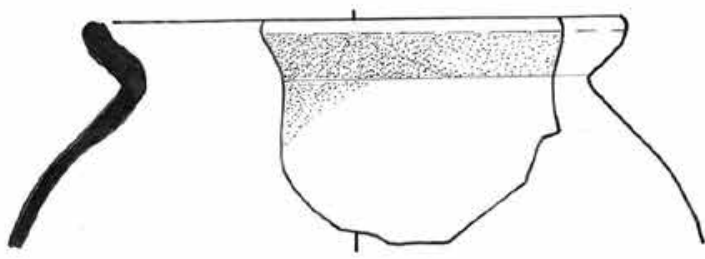

2013.14.3.26.

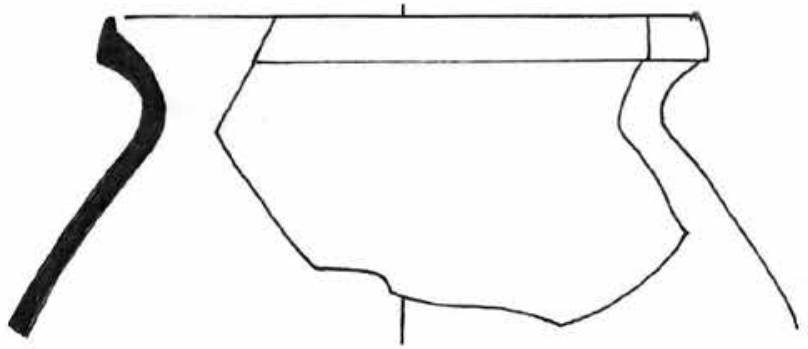

2013.14.7.3.

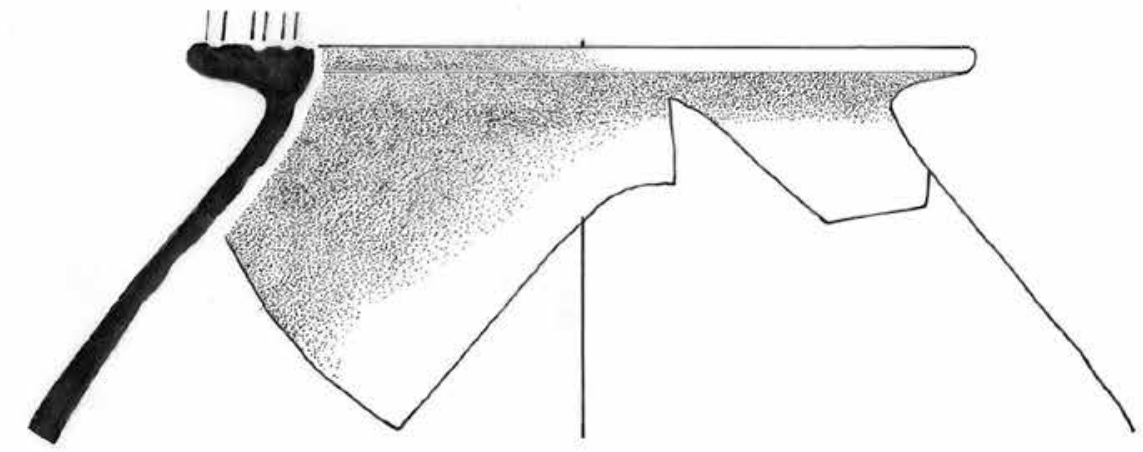

6 2013.14.5.4.

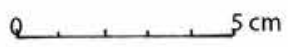

Fig. 14. Household pottery jug (1), mug (2), pot (3-6)

Acta Archaeologica Academiae Scientiarum Hungaricae 71, 2020 
bowl with a sharply undercut rim, which was found in the upper stony debris and the daub layer (2013.14.1.19.; Fig. 12.6-7). The latter type was made always of a gritty, hard-fired fabric. ${ }^{124}$

Bowl with a horizontal rim (15/17 pieces: Fig. $12.2-4)^{125}$ cups or larger bowl sizes (mouth diameter: $13-22 \mathrm{~cm}$ ) are also found. From the late $-4^{\text {th }}$ century, the spherical variants without shoulder carination are rare. After the horizontal rim come the short neck, the shoulder carination and the conical lower half. Its rim can be S-profilelike (2013.14.6.96., 97. etc.; Fig. 12.3), perhaps furrowed for a lid, or a simple horizontal rim. Its wall is sometimes lightly ribbed with traces of wheel (Fig. 12.4). On one fragment on and under the rim runs an incised wavy line (Fig. 11.2). ${ }^{126}$ Its fabric is always hard-fired, gritty, often whitish-grey. Those fragments with a sharply carinated shoulder and a conical base without a rim (2013.14.6.124.; 2018.1.13.37.) probably belong in this group, as do the bowls with a protruding shoulder (2013.14.6.118., 119.). Furthermore, based on analogies from Leányfalu, the pedestalled bowl fragment likely had a similar rim (Fig. 12.5). ${ }^{127}$ It can be found in all wings in the fort. ${ }^{128}$ There is an especially great number of bowls of this type found at the nearby watchtowers and forts along the Limes; sometimes they were also produced locally, e.g. at Leányfalu and Tokod. ${ }^{129}$ It can also be found from the late- $4^{\text {th }}$ century at forts of the Lower Danube, highland sites in Slovenia, and in the Barbaricum. ${ }^{130}$

Strainer bowl (2 pieces): bowls with a swollen rim, vertical wall and flat foot (2013.14.6.102.; 2013.14.20.12.). Both are from the daub layer. The earlier vessel is well-levigated, medium-hard fired. The later one is from a very gravelly, poorly levigated fabric.

It is a durable form, used in the $2^{\text {nd }}-4^{\text {th }}$ centuries. ${ }^{131}$

Jug (c. 41 pieces)

An earlier piece, or not belonging to household pottery, is the lower half of a small brick-coloured jug, with whitish slip on its surface (Fig. 6.4). The same slip can be found on a small vessel with a horizontally everted rim (2013.14.6.107. +2013.11.6.16.), on a wall fragment (2013.14.9.9.) and on a few storage vessel fragments (2013.14.3.8. +4.17.). grey fabric. ${ }^{132}$

Straight, grooved rim (2 pieces): 2013.14.1.22.; 2018.1.13. Traditional, late Roman jug form, hard-fired,

Jug with a straight, ungrooved rim, with a band handle starting at the rim. Fired white, gritty fabric (2013.14.20.25.: 2 pieces). Its further form is unclear.

Everted jug rim with band handle (2018.1.13.15.), with a small knob on the handle (2013.14.20.24.). On the other shoulder fragment with everted rim also found here, there is an incised wavy line (2013.14.20.13.), both of a yellowish-grey, gritty fabric. Several shoulder fragments from the daub layer, too, may have belonged to a similar form, but not all were fired white (Fig. 14.1).

Jug with collared rim (4 pieces): It has a narrower- and a wider-mouthed variant. On both there are several bands of incised wavy lines, on the rim, the shoulder and the belly. On the dividing line, which emphasises the shoulder carination, there are impressions; but the same kind of notches or circular impressions, too, can also be

${ }^{124}$ Otтомányi 2015a, 17-18, Fig. 2.4, Fig. 9.5, Fig. 16.4 (south wing); ОтTOMÁNYi 2018a, Table 7.7-8 (southern half of courtyard); OtTOMÁNYi 2018c, Fig. 5.2-3 (room I/N); LÁNYi 1981,77, Type 15, Fig. 9.8-9 (Tokod, lid); TomKa 2004, Table. 3.6 (Arrabona fort Migration Period phase 1b); VAŠIĆ 1982-1983, Fig. 11.10-12 (Čezava, second half of phase 6 : late- $4^{\text {th }}-$ mid $-5^{\text {th }}$ century).

${ }^{125}$ There are also many horizontally-everted small rim fragments, where the form cannot be ascertained. They could also have belonged to pots, e.g. 2013.14.6.61., 62, 94, 95. etc.

${ }^{126}$ OTTOMÁNYi 2015a, Fig. 5.5 (SW tower: wavy line on and under the rim); LÁNYI 1981, Fig. 15.1,4,6 (wavy line on the rim); OTtOMÁNYi 1991, Table 10.47-48a, 52 (wavy line on the rim); OTTOMÁNYI 1999, 353-354, Pl. IX.5 (Dunabogdány, after Valentinian); TeJRAL 1985, Fig. 8.4 (Jiřikovice: bundle of incised wavy lines on the shoulder); CIGLENEČKI 1984, Fig. 6.70 (Tinje), Fig. 9.98 (Korinjski hrib: with wavy line).

${ }^{127}$ OtTományi 1991, 16, Table 10.47 (glazed), 50, Table 36.3 (household pottery); LÁNYI 1981, 78, Fig. 15.1, 10-12 (Tokod); TEJRAL 1982, XLVI.1.
${ }^{128}$ OTtOMÁNYi 2015b, 698-700, Fig. 2.4-5 (west wing, with wavy line on one of the rims); ОтTомÁNYi 2015a, 18, Fig. 9.2-3 (south wing); ОттомÁnYi 2018c, 127, Fig. 5.5 (room I/N).

${ }^{129}$ LÁNYI 1981, 78, Type XXX-XXXI, Fig. 15.1-12; OtTOMÁNYi 1991, Table 9-10; OTTOMÁNYi 1999, 353-354, Pl. IX; OTTOMÁNYi 2004, 272, Table II.2-8 (Budakalász).

${ }^{130}$ VAŠIĆ 1982-1983, Fig. 11.1-2: Čezava, second half of phase 6 , late- $4^{\text {th }}-$ mid- $5^{\text {th }}$ century); CIGLENEČKI 2000 , Table 82.12 (Gradec bei Prapetno), Table 85.1-3 (Rifnik); From the turn of the $4^{\text {th }}$ and $5^{\text {th }}$ centuries, these bowls with Roman antecedents are also produced beyond the province, e.g. in the Upper Tisza region (Hernádvécse: SoÓs-BÁRÁNY-KÖHLER-PusZTAI 2017, Fig. 12.I.4-6, Pl. XIII.4).

${ }^{131}$ South wing: OTtOMÁNYI 2015a, 18, Fig. 2.2-3, Fig. 6.6; Courtyard: OTTOMÁNYI 2018a, 111, Table 11.1; GRÜNEWALD 1979, 49, Table 36.5-9; HárshegYi-OTTOMÁNYi 2013, Fig. 5.3.

${ }^{132}$ South wing: OTtományi 2015a, 20, Fig. 6.7; GRÜNEWALD 1979, 61, Table 55.7 and Table 56.7, 9. 
between two bands of wavy lines. Several neck and shoulder fragments were found with a similar decoration from the same upper daub layer (Fig. 11.3-4; Fig. 13.1 and 4), with fragments matching one of them from the upper level of room II/N. ${ }^{133}$ They are whitish-yellow and whitish-red, of a gritty, hard-fired fabric. The folds on the handle copy glass jug archetypes. Made with the same decoration and of the same fabric is a nearly intact jug with a missing rim from room III/S and the southern half of the courtyard. ${ }^{134}$ On the shoulder of undecorated collared rims (Fig. 13.2; 2013.14.19.5.), too, there may have been incisions which did not survive. This rim type is common in Gizellamajor, including its variants with both a narrower and wider mouth diameter. Everywhere they come from the upper destruction debris. ${ }^{135}$ This jug type, in terms of both design and layer, can be placed among the latest, $5^{\text {th }}$ century material of the fort. In the nearby forts, built during the Valentinian period and still operational during the first half of the $5^{\text {th }}$ century (Leányfalu, Tokod), it was produced locally in countless versions, often with incised wavy lines. ${ }^{136}$ The form, through its variant without decoration, or perhaps with traces of wheel, lives on until the middle/second half of the $5^{\text {th }}$ century in communities with late antique roots under Ostrogothic rule, e.g. Ordacsehi-Kistöltés. ${ }^{137}$ It also appears in Sarmatian and Moravian territories, as a foreign influence. ${ }^{138}$ On a small handled jug, of a gravelly fabric, with a body ribbed with traces of wheel, found in the daub layer, the rim did not survive (Fig. 13.3). Based on its design, it can be placed in the early- $5^{\text {th }}$ century group.

Handles: band handles clearly belong to jugs, sometimes to large variants. At the start of the handles knobs and folds imitating glass jugs are common (Fig. 13.1; 2013.14.20.24.). On the inside of a band handle fired white is a glaze spot. It is unclear whether there was glaze on the vessel, or it got on it during the firing process (2013.14.20.26.). The twisted handles are all made of the latest, gritty, yellowish-white fabric (Fig. 11.5). They can be found in other parts of the fort as well, as both glazed and household pottery. ${ }^{139}$ Analogies can be found in e.g. Tokod, Leányfalu, Moravian territory, etc. ${ }^{140}$ Ribbon handles can also belong to smaller mugs (e.g. 2013.14.19.3.). Fragments with an inverted foot and half vessels, too can be group with jugs.

Cup (3 pieces)

Thin-walled, everted-rimmed small cup fragments from the daub layer (2013.14.20.14.; 2018.1.13.10.) made of a yellowish-white, gritty fabric. The other, a horizontally-everted cup rim (2013.14.9.4.), is of a grey, hardfired fabric.

Pottery cup is a rare form in the late Roman Period. In the other rooms of the fort there are only a few household pottery cups. None of them resemble the fragments of room III/N. ${ }^{141}$

Mug/pot (c. 150 pieces)

It is difficult to group the small fragments into mug and pot forms respectively. If the mouth diameter cannot be measured, the wall thickness can help. Just 100 pieces are rim fragments. Around half are everted, around half are furrowed for lid. Some of the everted and straight rims are split on the outside by a line or groove (5 pieces). These are mug forms (sometimes possibly jugs). ${ }^{142}$ There are very few horizontally-everted rims (6 pieces); they are mostly pots. ${ }^{143}$ From the small rims, we are not always able to ascertain the form. Most common (around

\footnotetext{
${ }^{133}$ In the same upper daub layer there are several neck and shoulder fragments with a similar decoration, which, however, do not match (2013.14.6.53-56). It is possible that they belong to one of the large vessels (see Fig. 13.1 and 4). Similar shoulder fragments from the daub south of the gate (2013.14.20.30. and 2018.1.13.23.).

${ }^{134}$ Otтományi 2015a, Fig. 9.8; OtтomÁnYi 2018c, Table 8.3-4, 112; Shoulder fragments with a row of wavy lines and notches: OTTOMÁNYI 2015b, 4.1-3.

${ }^{135}$ In room I/W jug with a wider mouth: OTTOMÁNYI 2015b, Fig. 2.9-10 (period 4); southern building, room III: OTTOMÁNYI 2015a, 20-21, Fig. 9.9-11; southern part of the courtyard, upper daub debris: ОтTOMÁNYI 2018a, 112, Table 8.1, Table 11.2; room I/N, upper daub debris: ОтTомÁNYi 2018c, 128, Fig. 6.1.

${ }^{136}$ OtTOMÁNYI 1991, Table 15.2-5, Table 16.7, 11, Table 17.13a,16; LÁNYI 1981, 75, Type III, Fig. 3.

${ }^{137}$ Bocsi 2008, Fig. 13.5a.

${ }^{138}$ MASEK 2018, 243, Fig. 154 (settlement horizon 2); TeJRAL 1988, 280, Fig. 40.21 (horizon D2/D3).
}

\footnotetext{
${ }^{139}$ Room I/W (OtTOMÁNYi 2015b, Fig. 10.5: glazed).

${ }^{140}$ LÁNYI 1981, Fig. 5.3-6; OTTOMÁNYI 1991, Table 33.65 (on a Leányfalu mug form); TeJRAL 1985, Fig. 19.7 (Velké Němčice).

${ }^{141}$ OtTOMÁNYI 2015a, Fig. 2.5 (southern); OtTOMÁNYI 2015b, Fig. 2.12 (western); OTTOMÁNYI 2018c, 126, Fig. 4 (room I/N: 1 piece); OtтомÁNYI 2018a, Fig. 5 (courtyard: 2 pieces).

${ }^{142}$ South wing: OTTOMÁNYI 2015a, Fig. 10.3; western building: ОттомÁNYI 2015b, Fig. 3.3 (4.3\% of mugs); GróF 1992, Fig. 2; at Ács-Vaspuszta it can be dated started from layers dating to the Constantinian dynasty until the late- $4^{\text {th }}$ century: OTTOMÁNYI 1989 , Fig. 130-131/26-34 (with further references); ОттомÁNYI 1991, Table 27-28. 34-36 (Leányfalu); GASSNER 2000, 211, Fig. 182; GroH-SedLMAYER 2002, 284, Fig. 158.822, 1106 (Mautern, mid-4 ${ }^{\text {th }}$ $-5^{\text {th }}$ century); HoRVÁtH 2011a, 621-622, Fig. 8 (the majority of grey mug-pot forms of a gritty fabric at Keszthely-Fenékpuszta are these vessels with a grooved rim).

${ }^{143}$ HoRváth 2011a, 622-623, Fig. 9 (developed further from $2^{\text {nd }}-3^{\text {rd }}$ century antecedents).
} 


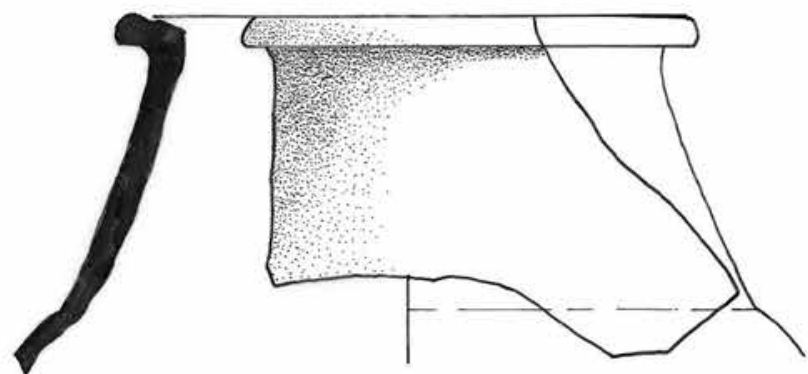

2013.14.16.1

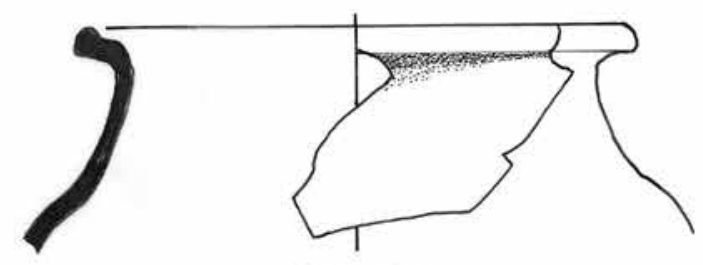

2013.14.6.3.

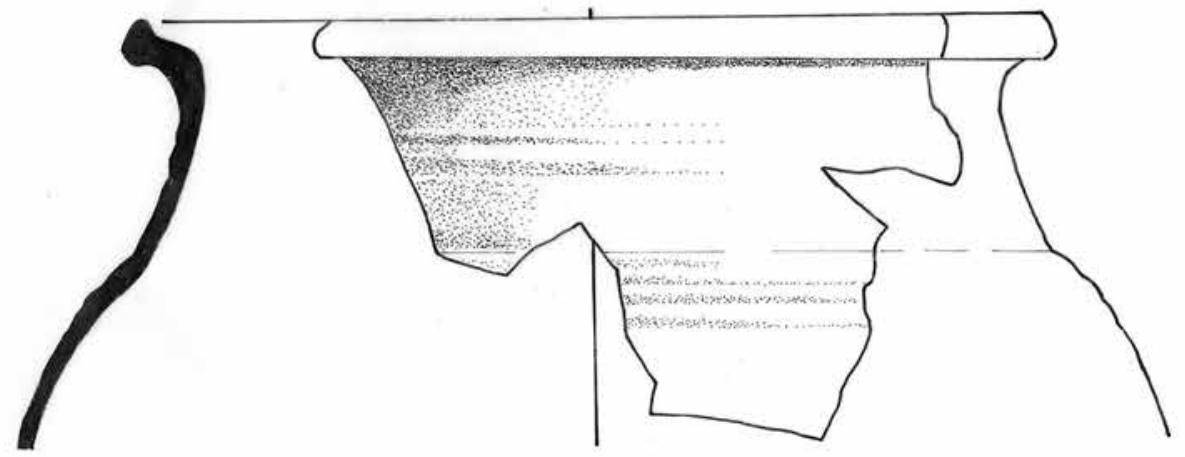

4

2013.14.22.4.

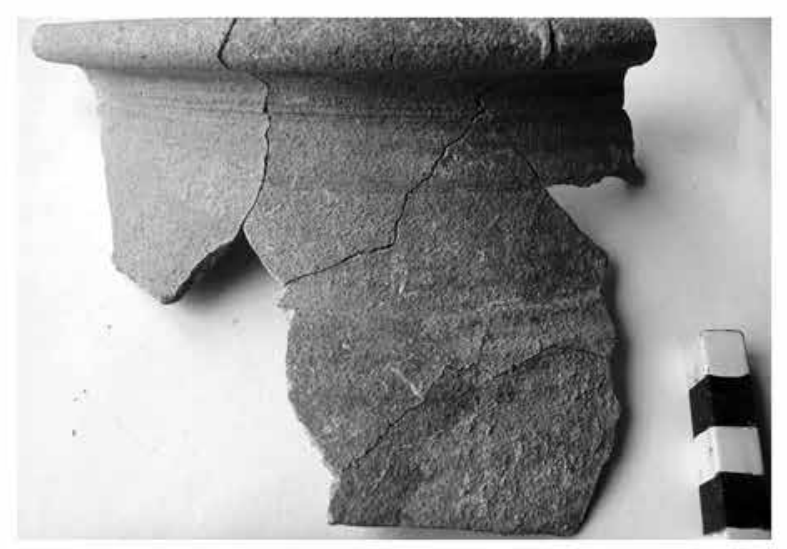

5

2013.14.22.4.

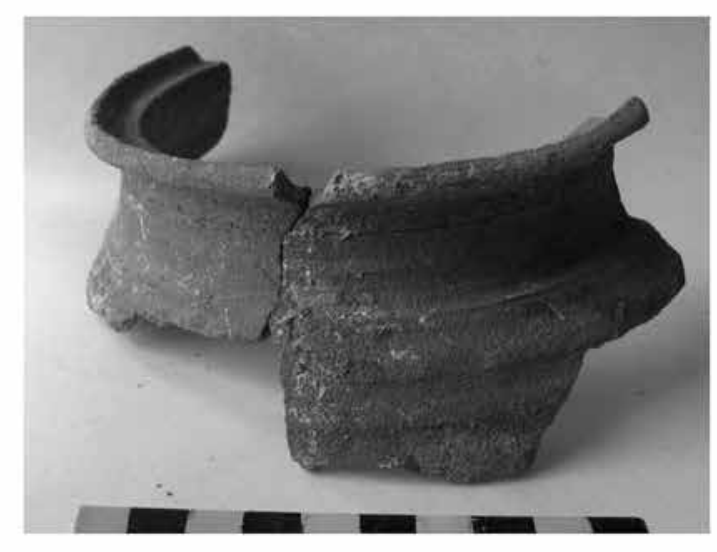

6

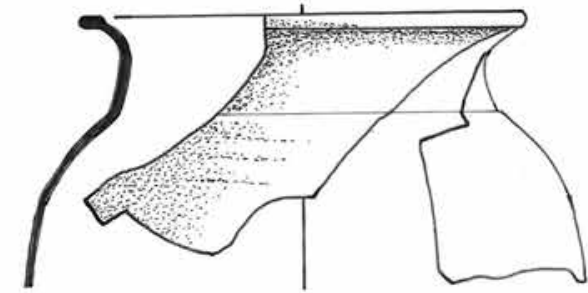

2013.14.20.10

3 
45 pieces) is the so-called Leányfalu type with downwards-widening neck and protruding shoulder, from smaller mugs to larger pots (with everted and also furrowed rim).

Around 32 pieces of mug and 40 pieces of pot fragments can be identified securely. The other fragments may have equally been mugs or pots (moreover, the wall and foot fragments may have belonged to bowl or jug forms).

Mug: A small intact vessel was uncovered on the upper floor (we can label it either a cup or a handleless mug). Its body is covered with traces of wheel, its fabric is gritty, hard-fired and white. Based on these, it belongs to the latest, $5^{\text {th }}$ century group (Fig. 11.6). Of the same fabric and design is the everted small rim fragment (cup or mug) from the daub behind the gate (2018.1.13.10.). Of the simple, everted rims a further two may have belonged to mugs. The smooth-surfaced, thin-walled vessel made of a brown, well-levigated, hard-fired fabric, found above the clayey, brown layer, is earlier (2013.14.4.14.). The everted mug rim, with the top cut straight, from the daub layer, is later (2013.14.6.26.). On a small, brick-coloured rim fragment, a yellowish-brown glaze spot can be seen; given that its fabric was medium-hard fired, it may also have been glazed originally (Fig. 14.2).

Furrowed mug rim (c. 6 pieces), from the excavation of the floor (2013.14.12.19.), the upper daub layer (2013.14.6.27., 59.; 2013.14.20.15.) and the daub behind the gate (2018.1.13.9.).

"Leányfalu" mug: with a furrowed, profiled rim (2013.14.6.7.; 2013.14.7.4.). There may be lines around its neck, or traces of wheel on its shoulder. Based on their characteristic shoulder carination, wall fragments, too, can be included here (e.g. 2013.14.6.38, 40.). ${ }^{144}$

Perhaps belonging to mugs were the thin-walled, white wall fragments with, similarly to jugs, several rows of wavy lines decorating their shoulder (2013.14.6.116.), with traces of wheel below. ${ }^{145}$ The thin-walled, white wall fragments, with a ribbed wall, without wavy lines, too may belong to mugs (e.g. 2013.14.6.3.). The small belly fragments with a handle start (mostly ribbon handles), too, can be connected with mugs (2013.14.1.61.; 2013.14.5.25.). Made of a gritty, grey or whitish-grey fabric. Among the flat feet, too, the smaller ones may have belonged here (e.g. 2013.14.12.40.).

Pot: Of the everted rim fragments (c. 5 pieces) one is deformed, a waster (Fig. 14.3). Based on its design, it still belongs to traditional, $4^{\text {th }}$ century pottery. It was found during the excavation of the upper floor. The other half of the rims is furrowed (around 6 pieces: Fig. $14.4-5$ ). ${ }^{146}$ Among the latter, a rib, too, may run under the rim (2013.14.6.57.).

"Leányfalu type": there are such pots with everted, straight-cut (2013.14.5.5-6.; 2013.14.6.2.) and also furrowed rims (Fig. 15; 2013.14.5.23.; 2013.14.20.17.). The earliest piece was made of a well-levigated, brickcoloured, medium-hard fired fabric (Fig. 15.1). It does not have a more precisely identified layer, but there appeared no characteristically late pottery alongside it (mixed with early Roman pottery). The type therefore already appears in the material dating to the construction of the fort, in the second half of the century. It, however, consists mostly of later vessels, made of a gritty, hard-fired fabric; often fired yellowish-white (28 pieces). $30 \%$ of the mug/pot forms of room III/N, 45 pieces, can be classified as belonging to this type. There are many such pieces in other parts of the fort as well. ${ }^{147}$ It is attested, with a ribbed surface, until the mid- $5^{\text {th }}$ century in the province, and, more rarely, in neighbouring Germanic territory. ${ }^{148}$

\footnotetext{
${ }^{144}$ The closest and most numerous analogies are from the Leányfalu workshop: ОттомÁNYi 1991, 11, Table 28.39c, Table 29.39a, 43, 45; Jeremić 2012, Fig. 4, Cat. No.273 (Saldum, Valentinian period); from Moravian territory (TEJRAL 1985, Fig. 19.3,5-6). For further analogies, see the section of pot forms.

${ }^{145}$ Analogies e.g. from Leányfalu (OTTOMÁNYI 1991, 12, Table 27.1-2, Table 43.8-9).

${ }^{146} \mathrm{~A}$ typical rim and form in late Roman pottery (GRÜNEWALD 1979, 60, Table 54.9-17; GroH-SEdLMAYER 2002, 259284, Fig. 157-158); CigleneČKI 2000, Table 87.1-2, Table 90.4-5, etc.; It spread not only in Pannonia, but in the surrounding Barbaricum as well, probably through Roman influence; but it was by then also being produced by local workshops (KULCSÁR-MérAI 2011, Fig. 17; MASEK 2018 159, Fig. 75-76; SoÓs-BÁRÁNY-KöHLER-PuSZTAI 2017, Fig. 12.II.6,8,13-15, Pl. VIII.4,8).

${ }^{147}$ West wing: over half of all mugs and pots of this type (ОттомÁNYI 2015b, 701, Fig. 3.6-7, 9-10); in the south wing only 16.4\% (Оттоми́NYi 2015a, 23, Fig. 2.6, Fig. 6.11, Fig. 10.5,8,9, 10, Fig. 16.5-6; Fig. 18.1; in the courtyard's material 19\% (ОтTомÁNYI

Acta Archaeologica Academiae Scientiarum Hungaricae 71, 2020
}

2018a, 112, Table 9.201504); room I/N (OTTOMÁNYi 2018c, Fig. 6.3); in the NW corner tower 1 piece (OTTOMÁNYI 2018b, Fig. 5.4).

${ }^{148}$ In Leányfalu, Pilismarót and Tokod a whole series of such vessels was produced from the Valentinian period until the first third of the $5^{\text {th }}$ century (in Tokod even further): LÁNYI 1981, 75, Typ. I, Fig. 1-2 (52.2\% of all fragments); ОттомÁNYi 1991, 11-12, Type 36-75, Table 28-34 and Map 5. In Leányfalu $70 \%$ of mugs and pots belong to this type; ОттомÁNYI 1996, 89-92, Fig. 8-9 (PilismarótMalompatak, 53\%); Intercisa: on the floor of a house burnt down during the Hun period (BóNA 1993, 236, drawing 67); OTTOMÁNY 2008, 170-171, Fig. 16.6-15 (Biatorbágy, Hun period settlement); with a shorter neck in South Pannonia, Keszthely-Fenékpuszta, etc. (JELINČIĆ 2015, Table 134.1; HoRvÁth 2011a, 623-624, Fig. 11; BocsI 2008, Fig. 7.1/1b, Fig. 8.2/1C, Fig. 13.Ib (Ordacsehi-Kistöltés), Fig. 14.Ib-c, VIA (Zamárdi); Bocsi 2011, 114-115, Table 3 (ZamárdiKútvölgyi-dủlö, $5^{\text {th }}-6^{\text {th }}$ century settlement); CIGLENEČKI 1984 , Fig. 2.19-21 (Gradec bei Prapetno); TeJRal 1985, Fig. 19.1,3,5-6; StuPPNER 2008, Fig. 5.4; GindELE-IstVÁNOvits 2009, Fig. 51.680B/8 (phase 5). 
Storage vessel (6 pieces)

Made with a traditional, everted, often swollen rim; grey; made of a well-levigated fabric, fired mediumhard or hard. The surface of a vessel with a horizontal, ribbed rim is smooth (Fig. 14.6). These types are present through four centuries; later variants are darker grey and harder. One variant has a whitish-yellow slip (its fabric is brick-coloured: $2013.14 .3 .8 .+14.4 .17$.$) .$

Lid (7 pieces)

Straight-ended, flatter lid from the excavation of the stone debris (Fig. 12.8). ${ }^{149}$ From the second half-end of the $4^{\text {th }}$ century, cover bowls with a sharply-undercut rim and conical body are the most characteristic (4 pieces and three others classified with bowls: Fig. $12.6-7) .{ }^{150}$ There are two lid knobs.

\subsubsection{Decoration}

The plastic decoration, ribbing or incision of the surface of household pottery, is characteristic of the latest vessels, which appear during the late- $4^{\text {th }}$ century. Broom strokes, used through 4 centuries, appear only on a few items (5 pieces). ${ }^{151}$

Ribbing with traces of wheel: can be found on 171 fragments, i.e. $23.4 \%{ }^{152}$ In terms of form, it mostly appears on mugs and pots, and within these especially on shoulder and belly of Leányfalu-type ones. ${ }^{153}$ It lives on also in $5^{\text {th }}-6^{\text {th }}$ century settlements. ${ }^{154}$ It also appears in Germanic and Sarmatian settlements on the other side of the Danube at the end of the $4^{\text {th }}$ century with a profiled rim, of a gritty fabric, with ribbed walls (through Roman influence, also produced by then by local workshops). ${ }^{155}$ On Moravian territory it appears in a $5^{\text {th }}$ century setting along with glazed and smoothed-in pottery. ${ }^{156}$ Rarely light ribbing can also be seen on the belly of jugs and the shoulder of bowls with a horizontally-everted rim.

Incised horizontal lines: they can appear as one or two encircling, horizontal lines, mostly to serve as division where the neck and shoulder meet; but the horizontal lines can also appear densely-packed, imitating traces of wheel (7 pieces). ${ }^{157}$ The latter, too, only appears on the latest vessels.

Incised wavy line (20 pieces): can appear on horizontal rims and under the rim (Fig. 11.2), the neck and shoulder of jugs with a collared rim, and the shoulder of pots, in one or two rows. Sometimes notches are used to emphasise the dividing lines between or above these, at the shoulder carination (10 pieces; Fig. 13.1,4; 2018.1.13.23. etc.). These can equally be both small circular impressions and sharp notches. Almost all vessels thus decorated are made of a gritty, yellowish-white fabric. Only a few jugs are made of a more traditional fabric, fired grey or reddishbrown (Fig. 14.1). This method of decoration and design is characteristic of early- $5^{\text {th }}$ century vessels, both of household pottery and glazed jugs. ${ }^{158}$

${ }^{149}$ OtTomÁnYi 2015a, 24, Fig. 5.9 (SW corner tower); JELINČIĆ 2015 , Table $160\left(1^{\text {st }}-4^{\text {th }}\right.$ century $)$.

${ }^{150}$ In room I/W: OTTOMÁNYI 2015b, 697, Fig. 4. 4-5; Otтományi 2015a, 24, Fig. 9.6-7, Fig. 18.3; HoRVÁth 2011a, 625, Fig. 7.5-6,8; GRÜNEWALD 1979, 64, Table 59.21-23 (Carnuntum, period 4); Bocsi 2008, Fig. 7a.1/IVb (Ordacsehi-Kistöltés, material group 1).

${ }^{151}$ Analogy: e.g. Leányfalu (ОтTомÁNYI 1991, Table 27. 33).

${ }^{152}$ In the south wing on $12.6 \%$ of household pottery (ОтTOMÁNYI 2015a, 24-25); in the west wing on 6\% (OTTOMÁNYI 2015b, 703)

${ }^{153}$ LÁNYI 1981, 75; HORVÁTH 2011a, 614-615; OTTOMÁNYI 2008, 170-171 (with further references). Zamárdi).
${ }^{154}$ Bocsi 2008, Fig. 8, Fig. 9.3/Ic, etc. (Ordacsehi,
${ }^{155}$ ISTVÁNOVITS-KuLCSÁR 2005; KULCSÁR-MÉRAI 2011, Fig. 12-14 (workshop in Üllö); VADAY 1988-1989, Fig. 46.1-6; MASEK 2018 149, Fig. 75.

${ }^{156}$ TejRal 1985, Fig. 20.2-7, Fig. 21.2,5,8,10, etc.

${ }^{157}$ E.g. 2013.14.1.49.; 2013.14.2.21. and 27.; 2018.1.13.35.; 2018.1.15.2

${ }^{158}$ OtToMÁNYi 1991, Table 32. 33, Table 42, Table 43.7-9; OtTománYi 1996, Fig. 18.1-3 (Pilismarót); LÁnYi 1981, Fig. 4.1-11, Fig. 5.7-12, Fig. 6, Fig. 7.1-11, Fig. 12 (Tokod); SzŐNYI 1984, 348, Fig. 5.1. (Győr, Martinovics Square); ToMKA 2004, Table 5.1 (Arrabona fort, Migration Period, period 1B); OTTOMÁNYI 2008, 173 (with further analogies); CIGLENEČKI 2000 (Slovenia, $4^{\text {th }}-6^{\text {th }}$ century); in Raetia-Noricum these vessels made of a highly gritty fabric, decorated with sunken wavy lines appear under the label "Horreumkeramik". Their form does not resemble pottery in Visegrád (GATTRINGERGRÜNEWALD 1981; RODRIGUEZ 1997; GASSNER 2000, 244-246; GROHSEDLMAYER 2013, 502-503, Fig. 7: Mautern, period 5).

Acta Archaeologica Academiae Scientiarum Hungaricae 71, 2020 


\subsubsection{The latest group}

Around 320 pieces of pottery belong here, nearly half (44\%) of the household pottery in the room. ${ }^{159} \mathrm{We}$ can distinguish the latest, late $-4^{\text {th }}$ century $-5^{\text {th }}$ century, group primarily based on the fabric, design and possibly decoration. There are also a few characteristic forms, which are chiefly made of this kind of fabric, and even if the design or form is different or more traditional, it is still newer compared to earlier Roman pottery. Some traditional forms, too, could be produced according to the new design. Ribbing the vessels' surface using traces of wheel also a new kind of decoration. It, however, appears not only on whitish-yellow, but also on usual grey, reddish-grey vessels. Therefore, to this late group belong several kinds of forms and designs. The boundary between $4^{\text {th }}$ and $5^{\text {th }}$ century pottery is sometimes uncertain. ${ }^{160}$

\section{Colour, fabric}

Belonging to the late group are primarily the white, yellowish-white, whitish-grey or reddish-white fragments (201 pieces). They may be fired grey in places, or their two sides fired to different colours. They are usually thin-walled, fired 'ringing' hard. Their fabric is gritty.

Based on the surface decoration (ribbing and wavy lines) and the form, also belonging to this latest group are the grey ( 86 pieces) and reddish-grey ( 22 pieces) vessels. The latter were either fired in layers, or the red vessel was fired grey in places. There are also 12 red, 1 reddish-brown and 2 light brown fragments.

\section{Form}

Among bowl forms, the latest are the bowls with a sharply carinated shoulder, a conical base, and a horizontally everted rim ( 2 pieces), or with an S profile and horizontal rim (3 pieces). On some, the rim is missing, only the characteristic lower part survived (4 pieces). The pedestalled bowl fragment, too, likely belonged to a bowl with such a rim. The rim and shoulder can be decorated with incised wavy lines, or the lower half with light ribbing (2 pieces).

Among jugs the latest are primarily the forms with a collared rim, decorated with rows of incised wavy lines, with a notched pattern between the rows. There are only a few, more traditional jugs with an everted or straight rim, fired white. Also belonging here are a few handles ( 3 pieces: twisted handle, band handle, ribbon handle) as well as the jug necks with ribs or incised wavy lines. There is one everted cup rim.

The majority of late fragments can be classified as belonging to mug and pot forms. Their rim is everted (4 pieces), furrowed (8 pieces), their surface often ribbed. Among them the most common are the Leányfalu types with a downwards-widening neck and protruding shoulder (45 pieces: of these 12 rims are white, 9 other colour), with a characteristic shoulder carination (15 pieces white, 8 pieces other colour), or without shoulder carination (1 white mug).

Furrowed rims and cover bowls with a sharply-undercut rim appear already during the second half of the $4^{\text {th }}$ century, yet they certainly lived on until the $5^{\text {th }}$ century.

\section{Decoration}

The majority of surfaces ribbed with traces of wheel, characteristic of the latest period, (171 pieces) appear on the above-mentioned mug-pot forms. They sometimes also appear on the lower half of jugs or bowls with a horizontal rim. They can be substituted with dense incisions (7 pieces).

Incised wavy lines decorate the neck and shoulder of jugs, possibly with impressions between the lines (white: 16 pieces wave, of these 8 notches and 1 impression without wave. Other colours: 4 pieces wave). They can also appear on larger vessels, e.g. pot shoulder ( 2 pieces). They also appear on the rim and neck of a bowl with a horizontal rim. They can be also combined with notches (10 pieces).

\footnotetext{
${ }^{159}$ In the south wing: $16.3 \%, 298$ pieces. Most in room III/S, 27\% (OTTOMÁNYI 2015a, 26).

${ }^{160}$ I did not include in this group the cover bowls with an undercut rim, unless their colour was white. Carinated bowls with a conical base were only included in the group if their bodies featured wavy lines or ribbing. All Leányfalu-type vessels were inActa Archaeologica Academiae Scientiarum Hungaricae 71, 2020
}

cluded, although there are grey pieces with unribbed walls (in case of rims we cannot tell whether or not the wall was ribbed). The type appears earlier, during the second half of the $4^{\text {th }}$ century/Valentinian period, but in the absence of stratigraphic data, the only way to distinguish the earlier and later vessels would be based on design and decoration. 


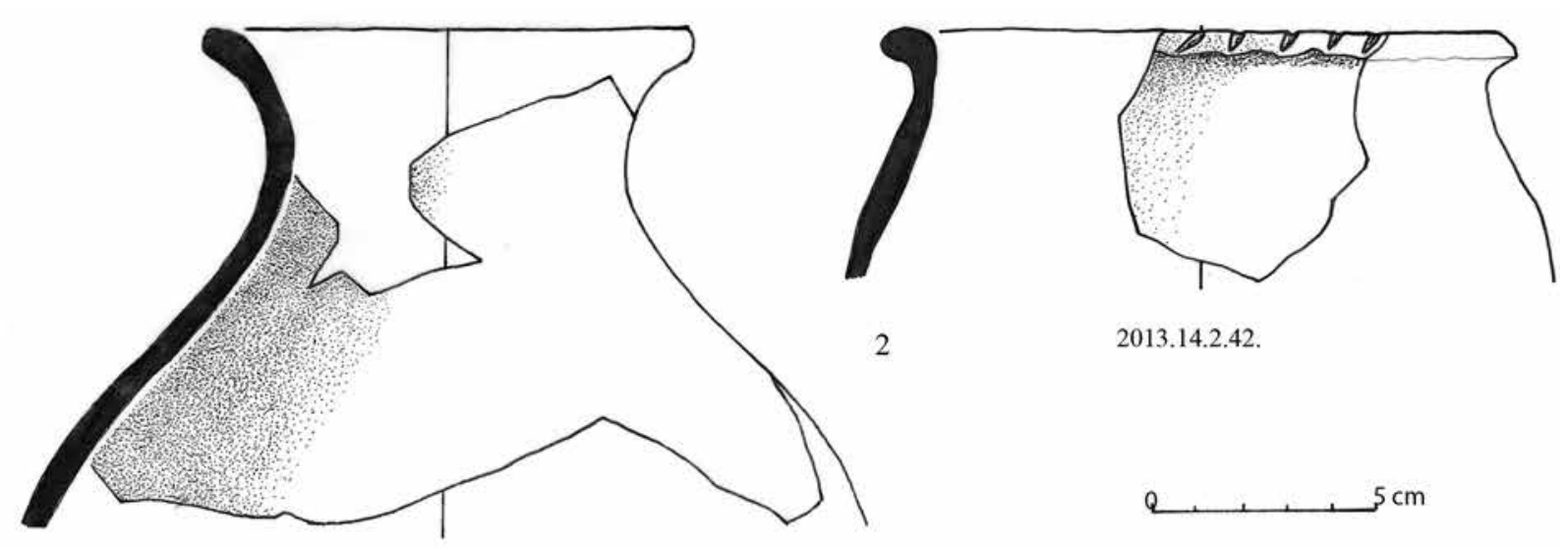

1 2013.14.6.84.

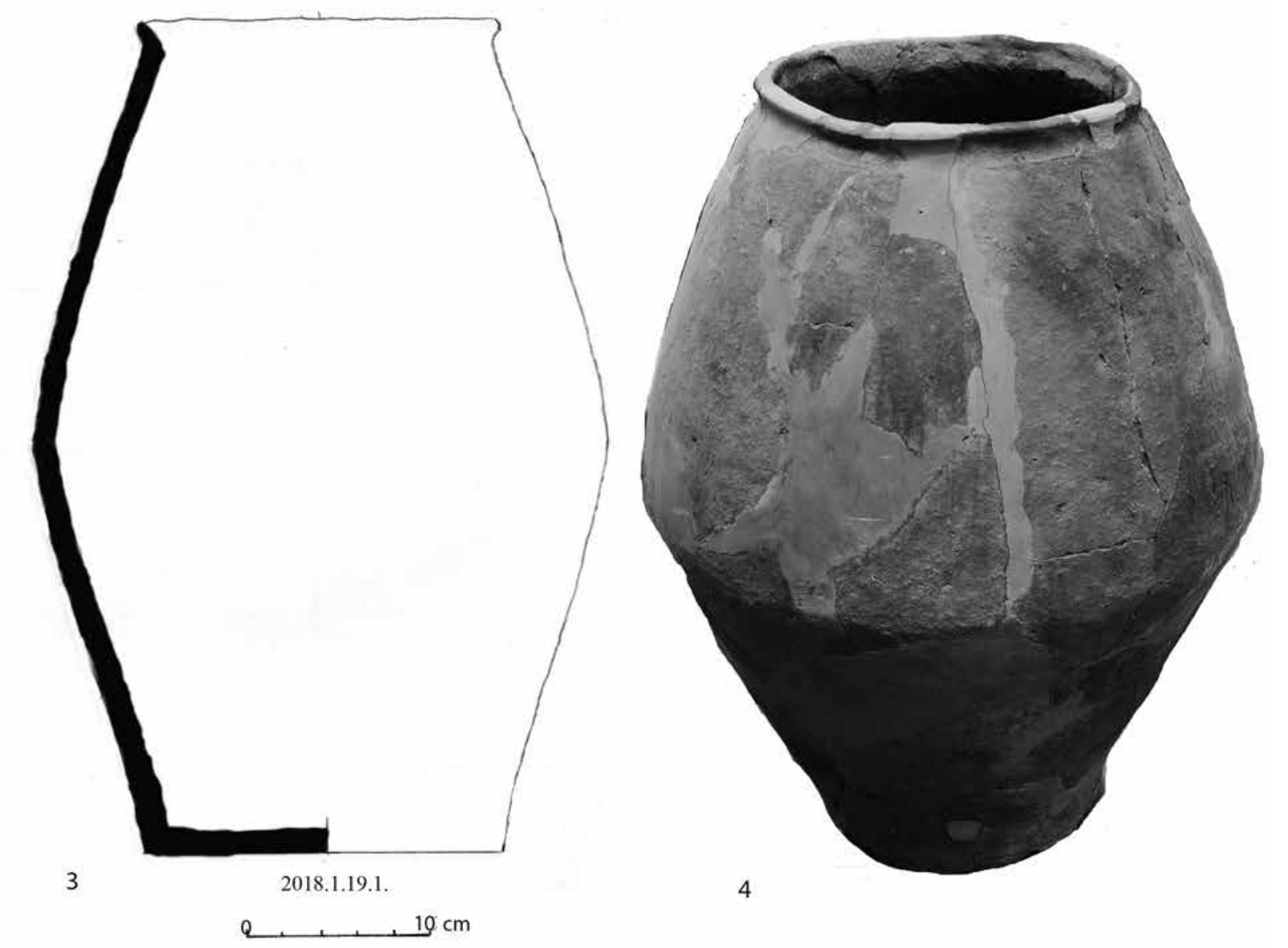

Fig. 16. Hand-made pots 


\subsection{Hand-made and slow-wheel-made pottery}

They can be found in nearly all layers of the room (their absence can only be a coincidence). There are, however, not nearly as many of them as of wheel-thrown pottery. In Pannonia they are common in the $1^{\text {st }}-2^{\text {nd }}$ century, but during the $2^{\text {nd }}-3^{\text {rd }}$ century it all but disappears. They appear mostly in the material of smaller villages, farther away from the roads. Along the Limes, hand-made pottery appears in increasing numbers from the second half of the $4^{\text {th }}$ century. Belonging to this group are locally-made, simple vessel forms used for cooking, primarily pots and bowls. Among them, vessel types connected with barbarian ethnic groups are very rare.

\subsubsection{Slow-wheel-made pottery}

There are 8 slow-wheel-made fragments. Their colour is varied, and due to the lower quality of firing, fired with spots or in layers: 3 dark grey, 1 greyish-red, 2 greyish-brown, 1 light brown and 1 reddish-brown. Secondarily fired rims and feet were possibly burnt during cooking. Four are well-levigated, the fabric of two has small pieces of gravel, one is coarse gravelly, and another has a rough, cracked surface. Two are smoothed shiny on the outside. ${ }^{161}$ All are pot fragments, three have an everted rim. On the exterior, two have dense lines, vertical and horizontal respectively. ${ }^{162}$

\subsubsection{Hand-made pottery}

Altogether 53 pieces. Few are just grey (6 pieces) or just brown (4 pieces). Usually, one side of the vessel was secondarily fired grey in places or black (7 pieces), or fired in layers during production: blackish-grey (6 pieces), brownish-grey (8 pieces), reddish-grey (4 pieces), reddish-brown (15 pieces).

Most common are the slightly gravelly, medium levigated fragments (27 pieces). Rare are the poorly-made vessels with larger pieces of gravel (5 pieces). They can be highly micaceous ( 7 pieces), possibly with large pieces of shiny, gold-coloured mica (2 pieces). The rest are well-levigated, fired medium hard (14 pieces). A flat foot fragment is smoothed on the outside (2013.14.2.44.).

Form: belonging to a bowl or cup is only one straight rim with a flat foot (2013.14.13.25.). ${ }^{163}$ The other slightly or more heavily everted rims likely belonged to pots. ${ }^{164}$ The neck of one is heavily inverted, almost jug-like (Fig. 16.1). ${ }^{165}$ On a more slightly everted rim run notches (Fig. 16.2). ${ }^{166}$

A large pot/storage vessel, which can be completely reconstructed, was found in the western half of the room, next to grave no. 94/1 (Fig. 16.3-4). ${ }^{167}$ Among the debris layer of the SE corner tower, too, was an intact, hand-made pot. ${ }^{168}$

\footnotetext{
${ }^{161}$ HoRváth 2011a, 639-641, Fig. 14.1-9; HoRVÁtH 2016.

${ }^{162}$ OtTomÁnyi 1999, 324, Pl. X.4,6, Pl. XI.1,3 (Dunabogdány, fort reduction); CigLENEČKI 1984, Fig. 4.45-49 (Tinje), etc.

${ }^{163}$ OtTOMÁNyi 2015b, Fig. 16.1; OtтomÁnyi 1999, Pl. XII.9; Pollak 1980, Table 124-125 (Straning), Table 41.1,6 (Maiersch), etc.; DroberJar-KNÁPEK-JARŮŠKovÁ 2008, Fig. 5.9 (Malá Haná); ElscheK 2017, Table 43.14-22 (Bratislava-Dúbravka, phase 3); JeLINČIĆ 2015, Table 149, 153-154, Table 154.

${ }^{164}$ OtTOMÁNYI 1999, 359-361, Pl. CIII.2-9 (with further references); ОттомÁNyi 2008, 173, Fig. 17.3,5 (Biatorbágy); HoRvÁth 2011a, 642, Fig. 16.10-15; JeLINČIĆ 2015, Table 148.

${ }^{165}$ Pollak 1980, Table 154.1 (Wien-Aspern); in a Hun period grave: Pusztataskony-Ledence 2, grave goods of grave no. 270/337 (MASEK 2018 Fig. 283).

${ }^{166}$ SOPRONI 1985, Table 15.2., Table 16.3 (Visegrád-Sibrik hill, house pit); HoRVÁTH 2011, 642, Fig. 14.14-15; MASEK 2018, 182, Table 23.8, Table 44.4 etc.; PollaK 1980, Table 154.2 (Wien-Aspern) Acta Archaeologica Academiae Scientiarum Hungaricae 71, 2020
}

Table 160.4 (Wien-Leopoldau), etc.; DROBERJAR-KNÁPEK-JARŮŠKOVÁ 2008, Fig. 4-5 (late Suebic pottery: Jevičko, Malá Haná); ElscheK 2017, Table 44.5,9-11, Table 61.12 (Bratislava-Dúbravka, phase 3); Bocsi 2008, Fig. 14.I/A2, B3, C3 (Zamárdi-Kútvölgyi-dűlő, $5^{\text {th }}-6^{\text {th }}$ century).

${ }^{167}$ The large, hand-made storage vessels in the late Roman period are characteristic of both the province and the neighbouring Sarmatian and Germanic settlements. Their forms, however, do not exactly match that of the Visegrád vessel. See MASEK 2018, Fig. 95; TeJRAL 1982, 6/2, 17/3-4, etc.; JELINČÍ́ 2015, S. 139.209 (Kiškorija Jug).

${ }^{168}$ GróF 1992, Fig. 1; OtтомÁNYi 2015a, Fig. 17.6; Based on the excavation diary, there were three large "Barbarian vessels" in this room. Two in 1996: in the western half of the trench on the yellow, clayey floor with mortar patches (1996. VII.10.), and the furnace pit of the lower level's heating flue (1996. VIII.15.). Of these only the one from 1998, published now, has been located so far (1998.VIII.16). Is it perhaps the same vessel, but during conservation and repackaging the date was copied incorrectly? 
A deformed, everted grey pot rim made of a gritty, gravelly fabric, from the excavation of the upper floor (Fig. 14.3) points at the local production of household pottery. Another very light, grey wall fragment burnt pitted and blistered may also be a waster (2013.14.6.134.). Additionally, we know of household pottery wasters from the west wing in the fort. ${ }^{169}$

Among glazed pottery, the fragment with a melted, shiny green glaze lump stuck on the glazed foot may perhaps be a waster (2013.14.6.90.). A similar glaze lump stuck on a vessel can also be found in room I/N. Waste proving local production were found in the south wing and the southern part of the courtyard. ${ }^{170}$

In room III/N there are no wasters among vessels with a smoothed or smoothed-in surface. A smoothed-in pot waster fragment was found in the south wing at the fort, underneath the floor of the room divided into two parts during the remodelling. ${ }^{171}$

During the second half-end of the $4^{\text {th }}$ century there are great similarities between the forms of household, glazed and smoothed/smoothed-in pottery, they often use the same types with different surface decorations. ${ }^{172}$ Their granular, gritty fabrics, which reflect pebble- and gravel-tempering along the Danube, are also similar. Based on the wasters (household pottery, glazed, smoothed/smoothed-in) and vessels with glaze spots, it is highly likely that at the Gizellamajor fort, too, pottery was produced locally in the late Roman Period. Sometimes materials from neighbouring sites/workshops (Tokod, Pilismarót-Malompatak, Leányfalu, Dunabogdány) are so similar that they raise the possibility of a shared workshop, or possibly a travelling potter. These travelling potters may have visited the forts along the Danube one after the other, producing vessels which reflected the taste of the mixed (Roman and barbarian) populace, from the Valentinian period until the $430 \mathrm{~s} .{ }^{173}$

\section{CONCLUSION}

Among the pottery at the Visegrád-Gizellamajor fort, in our case room III/North, we see a mix of familiar $4^{\text {th }}$ century, late Roman vessel forms and designs as well as new types and decorations which appear at the end of the Roman and the beginning of the Migration Period. Based on surface design and execution we can distinguish five basic groups among $4^{\text {th }}-5^{\text {th }}$ century pottery: household pottery - used for everyday baking and cooking, which represents the largest group -, glazed vessels, vessels with a smoothed surface - and among them vessels with smoothed-in decoration, which constitute a separate group both in terms of time and ethnic group. Among the pottery of the period we also find small numbers of slow-wheel-made and hand-made vessels.

In all groups of wheel-thrown pottery we can observe those changes - the appearance of new forms and decorations - which began in the final third of the $4^{\text {th }}$ century, then matured in and came to characterise the pottery of the first half of the $5^{\text {th }}$ century (Fig. 17). These changes can be seen not only in the Roman province, but also on Germanic and Sarmatian territory across the Danube. New forms are bowls with conical base and sharply-carinated belly (with a horizontal, swollen, or S-profile rim), biconical bowls, jugs with a collared rim, large jugs with two handles, and "Leányfalu"-type mugs and pots with a protruding shoulder. Of course there were several $4^{\text {th }}$ century forms which could survive into the $5^{\text {th }}$ century (e.g. cover bowls with a sharply-undercut rim, pots with a furrowed rim, etc.). As new surface ornaments, the plastic (incised, notched) patterns appear on both household and glazed pottery (primarily wavy lines). The fabric of the latest vessels was fired 'ringing' hard, often yellowish-white, and their surface very frequently decorated with heavy traces of wheel. A new group also appears: pottery with a

\footnotetext{
${ }^{169}$ OTTOMÁNYi 2015b, Fig. 5.3-4.

${ }^{170}$ OтTOмÁNYI 2018c, 124 (glaze lump inside a household pottery vessel); OTTOMÁNYI 2015a, 34; OTTOMÁNYI 2018a, 15, Table 5.2.

${ }^{171}$ OtтомánYi 2015a, 44, Fig. 16.11 (Leányfalu type mug/pot).

${ }^{172}$ Bowl with inverted rim: glazed (Fig. 4.1-2), smoothedin, household pottery (Fig. 12.1), hand-made; Cover bowl: smoothed (Fig. 11.5), household pottery (Fig. 12.6-7); Bowl with a segmented upper part and conical base: glazed (Fig. 4.3), smoothed (Fig. 7.4-5),
}

household pottery; Bowl with horizontal rim: glazed (Fig. 4.3-8), smoothed (Fig. 4.4), smoothed-in (Fig. 7.3), household pottery (Fig. 12.2-4); Jug with funnel-shaped rim: glazed, smoothed, smoothed-in (Fig. 9.3), household pottery; Jug with collared rim: glazed, smoothed, smoothed-in, household pottery (Fig. 13.1-3); Mugs with everted rim: glazed (Fig. 5.6), smoothed, smoothed-in, household pottery (Fig. 14.2), hand-made; Leányfalu type mug/pot: glazed (Fig. 5.7), smoothed (Fig. 9.6), household pottery (Fig. 15).

${ }^{173}$ HÁRSHEGYI-OTTOMÁNYI 2013, 486-489.

Acta Archaeologica Academiae Scientiarum Hungaricae 71, 2020 


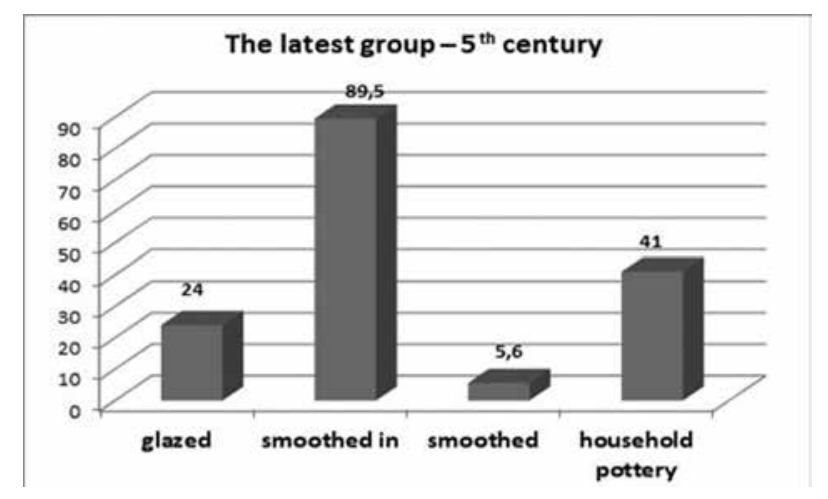

Fig. 17. The percentage of late Roman pottery among the various pottery groups

smoothed-in decoration. New research places its beginning to as early as the middle third of the $4^{\text {th }}$ century, ${ }^{174}$ but it only appears in the archaeological record in greater numbers during and after the Valentinian period. Among smoothed-in pottery, too, on the latest, $5^{\text {th }}$ century variants appears the blend of plastic and smoothed-in ornaments, the ribbing of the surface, etc. ${ }^{175}$

Changes in the pottery always reflect changes in the populace. At Visegrád-Gizellemajor, the population of the Roman fort at first grew when the residents of the civilian settlement outside its walls moved in - it was probably this that necessitated the remodelling during the Valenitian period. ${ }^{176}$ In spite of the decline, Roman rule continued in the final third of the $4^{\text {th }}$ century and indeed beyond. Hence, signs of reconstruction after 375 , too, can be observed in forts along the Limes. ${ }^{177}$ Thus, the latest, dry-walled, poorer-quality buildings inside the fort, too, need not necessarily be connected with a new barbarian populace; at most only with a mixed one. After all, during the last third of the $4^{\text {th }}$ century (or only at the turn of the $4^{\text {th }}$ and $5^{\text {th }}$ centuries), garrisons all along the Limes were supplemented with barbarian troops; partly from neighbouring Sarmatians and Germans, partly from peoples arriving from the East (Goths, Alans, Huns). ${ }^{178}$ Even if, in light of a new analysis of the sources, the settlement of foederati led by Alatheus and Saphrax in 380 cannot be proven, the continuous 'Barbarisation' of the population along the Limes cannot be denied. ${ }^{179}$ The foreign, barbarian elements brought with them their own forms and motifs and introduced them to the local Romans, setting a new trend. At the same time, they too adopted local customs and Roman workshops went on to produce for decades pottery reflecting this new, mixed taste. ${ }^{180}$ Although the fort was used for its intended purpose only until the 430s, the later Hun period settlers, too, left their mark in the archaeological record. Now it is difficult to ascertain among the pottery from the topmost destruction debris of the fort which were the vessels used until the fort was abandoned and which were those left behind perhaps by ethnic groups

${ }^{174}$ Tóth 2005, 375-380; HoRVÁtH 2011, 627-628.

${ }^{175}$ One of the most characteristic examples of this new type of pottery presented above is the assemblage of pottery at the Intercisa fort found on the floor of a burnt down, adobe house. Its destruction can be dated likely to the arrival of the Huns (between 425-434) (BÓNA 1993, 236, drawing 67).

${ }^{176}$ GRÓF 2016, 137. The end of civilian settlements around military bases and the gradual relocation or deliberate resettlement of residents behind the walls of the forts can be observed in several places along the Limes in Pannonia from the second half of the $4^{\text {th }}$ century; e.g. Györ (TOMKA 2004, 390), Intercisa (BóNA 2000, 70) etc.

${ }^{177}$ KovÁcs 2004, 139; this includes e.g. reducing the size of earlier Limes forts, which we can see, among others, at the Dunabogdány (Cirpi) fort next to Visegrád. The fort's archaeological record contains many vessels similar to those at Gizellamajor (ОттомÁNYI 1999); BÓNA 2000, 70-71.

${ }^{178}$ Among weapons found at the Gizellamajor fort, we see both Roman and foreign types (GRÓF 1992, 133, Table V); on the
Visegrád-Sibrik hill, among the finds of the semi-subterranean house and pit at the fort we see both Roman and hand-made (thought to be Quadic) pottery (SoPRONI 1985, 63-64, Table 11-16).

${ }^{179}$ For a detailed treatment see KovÁcs 2004, 130-143; KovÁcs 2016; VIDA 2011, 615-636; BIERBAUER 2015, 422-447.

${ }^{180}$ The mixed tastes applied not only to pottery, but also attire. Bone combs, too, were not part of Roman fashion; nonetheless they were often produced by local workshops during the late $4^{\text {th }}$ century. They were equally found in Roman contexts and in graves from the Hun period. The same applies to the Visegrád-Gizellamajor fort: hidden in the flue of room III/N, next to a green-glazed jug, was a double-sided bone comb (above it a new floor was still built during period 3 of the fort). Another double-sided bone comb, however, was deposited in a probably Hun period grave of a woman with an artificially distorted skull, dug later into the floor of the courtyard (GRóF 2016, 138-139). 
under Hunnic rule. Through the analysis of the material's composition, a trend can be identified: the quantity of the new pottery types in the various rooms of the fort increases continuously from the Valentinian period until the mid$5^{\text {th }}$ century. Large quantities are found especially in those places where later remodelling or additional structures can be attested. ${ }^{181}$ At the core, next to which appeared the vessels of a new design, remains late Roman pottery throughout. Even in the destruction debris it constitutes at least $50 \%$ of the vessels. ${ }^{182}$ The presence of African red slip vessels at the fort proves that even at the turn of the $4^{\text {th }}$ and $5^{\text {th }}$ centuries this imported ware still reached the Limes in Valeria from the Mediterranean and that there were people living at the fort for whom such ornamental pottery was still in demand.

Pottery at the fort fits organically with the finds from the other Limes forts still operating during the first third of the $5^{\text {th }}$ century in the Danube Bend. Furthermore, the role of the Danube as a boundary was coming to an end; and the pottery of Roman, Sarmatian and Germanic sites - which developed from different foundations -, too, came to share many traits in this age of the late Roman-early Migration Period.

\section{CATALOGUE OF OBJECTS PRESENTED IN THE TABLE}

\section{Abbreviations used in the catalogue and the tables}

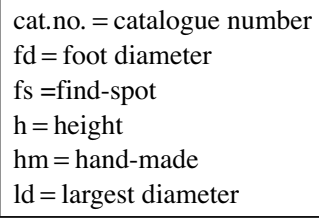

Fig. 4. Glazed bowls

1. 2013.14.6.85. Brick-coloured, with traces of glaze burnt pitted inside and outside. Well-levigated, hard-fired. Md: $18 \mathrm{~cm}, w t: 0.8 \mathrm{~cm}$.

2. 2013.14.2.2. + 2013.14.3.1. Brick-coloured, with a very thin grey layer inside under the glaze. Light, greenish-brown glaze on the inside. Well-levigated, fired medium hard. Md: $16 \mathrm{~cm}$, h: $4.5 \mathrm{~cm}$, wt: $0.5 \mathrm{~cm}$.

3. 2013.14.15.1. Grey, with a thin red layer on the outside. Shiny, greenish-brown glaze on the inside. Well-levigated fabric, fired medium hard. Md: $24.5 \mathrm{~cm}$, wt: $0.7 \mathrm{~cm}$.

4. 2013.14.6.17. Brick-coloured, some parts secondarily fired grey. Traces of greenish-brown glaze burnt pitted on the rim and on the inside. On the outside: smoothed with horizontal bands. Groove around the two edges of the rim. Well-levigated fabric, hard-fired. Md: $24.5 \mathrm{~cm}$, fd: $14.5 \mathrm{~cm}, \mathrm{~h}: 4.5 \mathrm{~cm}$, wt: $0.7-0.8 \mathrm{~cm}$.

5. 2013.14.6.87. Rim ribbed with light grooves. On the outside, impressions around the neck. Dark red, with grey layers; rim and inside covered with burnt glaze. Gritty, hard-fired fabric. Md: $29 \mathrm{~cm}$, wt: $0.4 \mathrm{~cm}$.

6. 2013.14.6.86. Impressions around the edge of the rim. Yellowish-grey, with burnt glaze on the inside. Gritty, hard-fired fabric. Md: $17.5 \mathrm{~cm}$, wt: $0.4 \mathrm{~cm}$.

7. 2018.1.13.1. Edge of rim wavy, with a groove around its two edges. Traces of burnt, light-coloured glaze on the rim. Whitish-red, gritty fabric, fired 'ringing' hard. Md: $16 \mathrm{~cm}$, wt: $0.3 \mathrm{~cm}$.

8. 2013.14.20.1. Wavy rim, with a groove around its two edges. Brick-coloured, with glaze burnt pitted on the rim and on the inside. Glaze spots/bands on the outside. Gritty, hard-fired fabric. Md: $14.4 \mathrm{~cm}$, wt: $0.2 \mathrm{~cm}$.

Fig. 5. Glazed mortaria, jugs, mugs

1. 2013.14.4.1. +2013.14 .21 .2 . Edge of rim segmented with ribs. Grey, secondarily fired. Dark green glaze burnt black on the rim and on the inside. Well-levigated, hard-fired fabric. Md: $27 \mathrm{~cm}$, wt: $0.7 \mathrm{~cm}$.

${ }^{181}$ OtтомÁNYi 2015a, 48, Fig. 24-25 (room III/S and SW tower).

${ }^{182}$ If we accept that the majority of residents in Valeria were resettled around 425 and the Huns settled new ethnic groups behind the walls of the old Limes forts (То́тн 2005, 384-385), then this either does not apply to Visegrád-Gizellamajor, or the pottery of the destruction debris by all means has to be dated prior to Hunnic rule. Among the pottery of the fort, so far no such types can be attested, which, as e.g. in the case of jewellery (see GRÓF 2016), are characteristic exclusively of the Hun period. 
2. 2013.14.21.1. Brick-coloured, fired grey in places. Dark green glaze, shiny on the inside, burnt on the rim. Well-levigated, hardfired. Md: $27 \mathrm{~cm}$, wt: $0.7 \mathrm{~cm}$.

3. 2013.14.6.88. Worn green glaze on the rim and on the inside. Fabric fired in layers, red on the outside, grey on the inside. Welllevigated, medium-hard fired. Md: $27 \mathrm{~cm}$, wt: $0.7 \mathrm{~cm}$.

4. 2013.14.19.1. Pale brick-coloured, with worn, burnt green glaze on the inside. Well-levigated fabric, medium-hard fired. Md: $14 \mathrm{~cm}$, wt: $0.5 \mathrm{~cm}$.

5. 2013.14.1.9. (Fig. 10.3). Dark grey, with a red layer on the inside and burnt dark green glaze on the outside. Stamped pattern on the neck. Well-levigated, medium-hard fired. Neck diameter: $4.5 \mathrm{~cm}$, wt: $0.4 \mathrm{~cm}$.

6. 2013.14.20.2. Brick-coloured, with burnt, perhaps green glaze on the outside. Well-levigated fabric, medium-hard fired. Md: $8.3 \mathrm{~cm}$, wt: $0.6 \mathrm{~cm}$.

7. 2013.14.6.20. +43. Thin-walled, light grey. On the outside surface covered in secondarily burnt, pitted glaze (traces of running and burnt glaze below). Gritty, hard-fired fabric. Ld: $13 \mathrm{~cm}$, wt: $0.3-0.4 \mathrm{~cm}$.

Fig. 6. Jugs

1. 2013.14.7.1. (Fig. 10.1). Worn, green glaze on the outside. Wall pierced under the handle, torn off on the other side in a circular spot. Grey, with a red layer on the outside. Well-levigated, hard-fired. Md: $4 \mathrm{~cm}, \mathrm{fd}: 5.5 \mathrm{~cm}, \mathrm{~h}: 19.5 \mathrm{~cm}$, wt: $0.3 \mathrm{~cm}$.

2. 2013.14.6.1. Reddish-brown inside and outside, carination grey in layers. Around its wall, 3 rows of different-sized dents separated by rows of notched and stitched ornaments. Dark green glaze on the outside, secondarily burnt black in places. Well-levigated, micaceous, hardfired fabric. Extant h: $23 \mathrm{~cm}$, ld: $14 \mathrm{~cm}$, fd: $7.5 \mathrm{~cm}$, wt: $0.6 \mathrm{~cm}$.

3. 2013.14.22.5. + 13. (Fig. 10.4). Dark red, fired grey in places. Large band handle start on the belly, flat ribbing on the outside of the body. The ribs (traces of wheel) are horizontally smoothed; smoothed-in lattice pattern on the shoulder. The smoothed-in ornament is shiny, darker than the fabric, thin-lined. Its fabric and thin-walled design resembles household pottery. Fd: $8.3 \mathrm{~cm}, 1 \mathrm{~d}: 19 \mathrm{~cm}$, h: $21 \mathrm{~cm}$, handle: $3.5 \times 0 . \mathrm{cm}$, wt: $0.3 \mathrm{~cm}$.

4. 2013.14.6.64. Red, with traces of white slip on the outside. Well-levigated, medium-hard fired fabric. Fd: $4 \mathrm{~cm}, \mathrm{~h}: 7.5 \mathrm{~cm}$, wt: $0.6 \mathrm{~cm}$.

Fig. 7. Smoothed and smoothed-in bowls

1. 2013.14.9.3 (+ 2013.14.5.3.). Grey, with thin brown layer on the inside, smoothed surface on the outside. Pierced under the rim. Well-levigated, micaceous, medium-hard fired. Md: $24 \mathrm{~cm}$, wt: $0.7-0.8 \mathrm{~cm}$.

2. 2013.14.19.4. Pale red, some fragments fired grey. On the outside, two encircling grooves under the rim. Surface horizontally smoothed inside and outside. Well-levigated, micaceous, medium-hard fired. $\mathrm{Md}: 23.5 \mathrm{~cm}, \mathrm{~h}: 7.5 \mathrm{~cm}, \mathrm{fd}: 9.5 \mathrm{~cm}$, wt: $0.5-0.7 \mathrm{~cm}$.

3. 2013.14.1.20. Grey. The outer edge of the rim made wavy with barely visible impressions. Rim and outside smoothed with horizontal bands, on the inside (almost contiguously) smoothed-in with vertical bands. Foot contiguously smoothed. Well-levigated, medium-hard fired fabric. Md: $27 \mathrm{~cm}, \mathrm{fd}: 18 \mathrm{~cm}, \mathrm{~h}: 5 \mathrm{~cm}$, wt: $0.7 \mathrm{~cm}$.

4. 2013.14.1.18. Dark grey, with shiny, black, horizontal smoothing on the outside. On the inside smoothing matches the colour of the fabric. Well-levigated, medium-hard fired. Md: $21.6 \mathrm{~cm}$, wt: $0.7 \mathrm{~cm}$.

5. 2013.14.1.21. (+ 2013.13.23.4.). Fired light grey on the inside, darker grey on the outside. Horizontally-smoothed on the outside (with thin bands). Smoothing is shiny and matches the colour of the fabric. Well-levigated, with small pebbles, hard-fired. Md: $15 \mathrm{~cm}$, wt: $0.4 \mathrm{~cm}$.

6. 2018.1.13.19. Dark, blackish-grey, carination lighter, red in layers. On the outside the surface is smoothed contiguously shiny, black. Well-levigated, hard-fired, highly micaceous fabric. Md: $15 \mathrm{~cm}$, wt: $0.4 \mathrm{~cm}$.

7. 2013.14.4.13. Light grey, with a darker, smoothed surface on the outside. Well-levigated, not hard-fired. Md: $20 \mathrm{~cm}$, wt: $0.6 \mathrm{~cm}$.

8. 2013.14.6.33. Light grey. A band of smoothed-in vertical lines around the neck. Contiguously smoothed below the belly. The smoothed-in ortnaments are barely shiny, thin-lined. Well-levigated medium-hard fired fabric. Md: $12.5 \mathrm{~cm}, \mathrm{wt}: 0.4 \mathrm{~cm}$.

9. 2013.14.6.52. (= Fig. 10.5). Light brown. Two bands of smoothed-in ornaments around the shoulder: double wavy line in the upper band, vertical lines underneath. Horizontally smoothed on the neck and under the belly carination. The smoothed-in ornaments are shiny, darker than the colour of the fabric, thick-lined. Well-levigated, micaceous, hard-fired fabric. Neck diameter: $10 \mathrm{~cm}, 1 \mathrm{~d}$ : $16 \mathrm{~cm}$, wt: $0.3 \mathrm{~cm}$. 
Fig. 8. Jug fragments with smoothed-in decoration

1. 2013.14.23.1. + 2013.13.6.238. ${ }^{183}$ (Fig. 10.6). Dark grey. Smoothed-in vertical bands on the neck, below it a smoothed-in horizontal line emphasises the protruding shoulder. This is followed by a smoothed-in wavy line in a band with a matt base. On the belly is a groove, emphasised with horizontal smoothed-in decoration. Contiguously smoothed surface below. The smoothed-in decoration is shiny, darker than the colour of the fabric, black, thick-lined. ${ }^{184}$ Well-levigated, not hard-fired. Ld: $18.5 \mathrm{~cm}$, neck diameter: $8 \mathrm{~cm}$, wt: $0.7-0.8 \mathrm{~cm}$.

2. 2013.14.12.11. Light grey. Horizontally (somewhat haphazardly) smoothed on the belly. There is a break in the smoothing at the band handle start. An incised line around the shoulder, with smoothed-in diagonal lines above. The smoothed-in ornament is shiny, matches the colour of the fabric, thin-lined. Well-levigated, hard-fired fabric. $\mathrm{Ld}: 17 \mathrm{~cm}$, wt: $0.5 \mathrm{~cm}$.

3. 2013.4.17.9. Grey. Band handle vertically smoothed. Above the belly carination - framed by a flat rib - a smoothed-in pattern begins (diagonal bands?, triangle?). There is a break in the pattern under the handle. Lattice pattern on the other side of the handle (thin-lined, shiny smoothed-in decoration). Horizontal smoothing on the belly. Well-levigated, medium-hard fired fabric. Ld: $21 \mathrm{~cm}$, handle width: $3.5 \mathrm{~cm}$, wt: $0.5 \mathrm{~cm}$.

4. 2013.14.1.37. Light grey. Smoothed-in lattice pattern on the shoulder (the pattern stops under the handle), bordered above by a groove. The smoothed-in decoration is shiny, matches the colour of the fabric, thick-lined. Well-levigated, micaceous, hard-fired fabric. Ld: $20 \mathrm{~cm}$, wt: $0.5 \mathrm{~cm}$.

Fig. 9. Smoothed and smoothed-in jug and mug/pot fragments

1. 2013.14.6.6. Reddish-brown, fired grey in places, with a barely shiny, contiguous smoothed surface on the outside. Well-levigated, hard-fired fabric. Neck diameter: $4.5 \mathrm{~cm}$, ld: $16.5 \mathrm{~cm}$, wt: $0.5 \mathrm{~cm}$, handle: $3 \times 1 \mathrm{~cm}$.

2. 2013.14.13.15. Grey. The vertical smoothed-in decoration on the neck is shiny and matches the colour of the fabric (it breaks at probably where the handle used to be). Well-levigated, hard-fired. Neck diameter: $12 \mathrm{~cm}$, wt: $0.5-0.6 \mathrm{~cm}$.

3. 2013.14.13.12. Dark grey. Rim horizontally smoothed on the inside, the handle vertically smoothed, with vertically smoothed-in bands on the neck. Between the bands in the beginning of smoothed-in pattern (wavy line?, triangle filled with diagonal lines?). Below the handle, on the jug's shoulder begin smoothed-in vertical and lattice pattern-like lines. The smoothed-in decoration is shiny, matches the colour of the fabric. Well-levigated, hard-fired fabric. Md: $16.8 \mathrm{~cm}$, wt: $0.6 \mathrm{~cm}$, handle: $3 \times 1.4 \mathrm{~cm}$.

4. 2013.14.20.11. + 28. (+34.). Reddish-brown. On the neck, between vertically smoothed bands is a smoothed-in vertical wavy line (Murga-type motif). Lattice pattern above the shoulder carination, with vertical smoothed-in lines in a band below. This is followed by a contiguous, horizontal smoothing on the belly. The smoothing and the smoothed-in decoration are shiny, matching the colour of the fabric. Welllevigated, medium-hard fired, almost soft-fired fabric. The surface of the vessel is partially torn off, of a very poor quality; the smoothing is worn, barely visible. Belly fragment no. 34 (not drawn), too, probably belongs to it. On that fragment traces of wheel emphasised by smoothed horizontal bands can be seen on the outside (the fragments do not fit together). Md: $13 \mathrm{~cm}, 1 \mathrm{~d}: 19 \mathrm{~cm}, \mathrm{wt}: 0.3-0.4 \mathrm{~cm}$.

5. 2018.1.13.22. Dark red, with shiny smoothed-in decoration matching the fabric's colour on the outside. Lattice pattern above, with vertical lines under the slightly protruding shoulder, bordered below by horizontal smoothing. Well-levigated, medium-hard fired. Size: $4 \times 3.2 \times 0.4 \mathrm{~cm}$

6. 2013.14.19.11. Brownish-red, with a darker, shiny, horizontally-smoothed surface on the outside. Well-levigated, hard-fired. Md: $11.4 \mathrm{~cm}$, wt: $0.3 \mathrm{~cm}$.

Fig. 10. Glazed (1-3) and smoothed-in pottery (4-6)

1. 2013.14.7.1. = Fig. 6.1.

2. 2013.14.1.10. Glazed cup fragment, with stitched (pastry wheel-like) decoration under a rib on the outside, on a light green glaze. Yellowish-grey, well-levigated, hard-fired. Size: $3 \times 2.5 \times 0.5 \mathrm{~cm}$.

2013.14.1.11. Jug fragment, with shiny, greenish-brown glaze and impressed decoration on the outside. Grey, well-levigated, medium-hard fired. Size: $3.5 \times 2 \times 0.5 \mathrm{~cm}$.

3. 2013.14.1.9. = Fig. 5.5.

4. 2013.14.22.5. =Fig. 6.3.

5. 2013.14.6.52. = Fig. 7.9

6. 2013.14.23.1. =Fig. 8.1.

${ }^{183}$ One vessel with vessels 2013.13.2.11-12. and 2013.13.9.2. and 2013.13.11.27. and 2013.13.16.91. and 2013.14.23.1.
${ }^{184}$ Except fragment 2013.13.2.11-12., which is brownishgrey with a shiny, darker smoothing. This was not fired black, but belongs to the same vessel. 
Fig. 11. Smoothed (1) and household pottery (2-6)

1. 2013.14.19.4. = Fig. 7.2.

2. 2013.14.1.17. Bowl fragment with a horizontally everted rim. On and under the rim runs an encircling incised wavy line. Light green, gritty, hard-fired fabric. Rim length: $6 \mathrm{~cm}, \mathrm{wt}: 1.4 \mathrm{~cm}$.

3. 2013.14.6.103. (Fig. 13.1). Whitish-yellow, fired grey in places. Several rows of incised wavy lines around the rim and shoulder, divided by grooves. Notches on the shoulder carination. Gritty, hard-fired fabric, household pottery. Md: $7 \mathrm{~cm}$, extant h: $15 \mathrm{~cm}, 1 \mathrm{~d}: 13 \mathrm{~cm}$.

4. 2018.1.13.23. Pot shoulder fragment. White on the outside, light grey on the inside, fired in layers. Incised wavy line on the neck, shoulder carination decorated with notches, followed by another row of wavy lines. Household pottery, gritty, fired 'ringing' hard. Size: $5 \times 6.5 \times 0.5 \mathrm{~cm}$

5. 2013.14.6.49. Twisted handle fragment. Household pottery of a yellow, gritty, hard-fired fabric. Size: $9.5 \times 3 \times 3.5 \mathrm{~cm}$.

6. (Fig. 13.5). Yellowish-white, decorated with dense traces of wheel outside on the shoulder. Fired greyish-black in places. In a large spot on the rim and inside and outside rust-coloured discolouration. Glued, intact vessel. Md: $8 \mathrm{~cm}, \mathrm{~h}: 9 \mathrm{~cm}, \mathrm{fd}: 4.5 \mathrm{~cm}$, wt: $0.4 \mathrm{~cm}$. Fs: floor, room built in the north wing, to the west and south of the gate (= room III/N), 1993. ${ }^{185}$

Fig. 12. Household pottery bowls (1-5), lids (6-8) and spindle whorls (9-11)

1. 2013.14.10.3. Grey, well-levigated, hard-fired fabric. Md: $23 \mathrm{~cm}, \mathrm{~h}: 4 \mathrm{~cm}$, wt: $0.5 \mathrm{~cm}$.

2. 2013.14.5.7. Blackish-grey, gritty, micaceous, hard-fired fabric. Wall lightly ribbed. Md: $22 \mathrm{~cm}, \mathrm{~h}: 4 \mathrm{~cm}, \mathrm{wt}: 0.3 \mathrm{~cm}$.

3. 2013.14.20.16. Blackish-grey, carination is lighter. Gritty, hard-fired fabric. Md: $15.7 \mathrm{~cm}$, wt: $0.5 \mathrm{~cm}$.

4. 2018.1.13.13. Dark grey, gritty, well-levigated household pottery, fired 'ringing' hard. Wall lightly ribbed. Md: $13 \mathrm{~cm}, \mathrm{wt}: 0.3 \mathrm{~cm}$.

5. 2013.14.6.50. Household pottery of a yellowish-white, gritty, hard-fired fabric. Fd: $7.5 \mathrm{~cm}$, wt: $0.4-0.6 \mathrm{~cm}$.

6. 2013.14.3.13. Dark grey, carination is lighter, secondarily fired. Gritty, hard-fired fabric. Md: $19 \mathrm{~cm}, \mathrm{wt}: 0.5 \mathrm{~cm}$.

7. 2013.14.6.93. Dark grey, gritty, hard-fired fabric. Md: $16.6 \mathrm{~cm}$, wt: $0.5 \mathrm{~cm}$.

8. 2013.14.13.4. Brownish-red, well-levigated, hard-fired fabric. Md: $12 \mathrm{~cm}$, wt: $0.7 \mathrm{~cm}$.

9. 2013.14.6.145. Reddish-brown, gravelly, hard-fired fabric. Spindle whorl drilled in the middle. Diameter: 2.8 and $4 \mathrm{~cm}, \mathrm{~h}: 3.5 \mathrm{~cm}$.

10. 2013.14.16.21. Light grey, well-levigated household pottery. Diameter: $3 \mathrm{~cm}, \mathrm{~h}: 1.5 \mathrm{~cm}$.

11. 2013.14.16.22. Reddish-grey, well-levigated household pottery. Diameter: $4 \mathrm{~cm}, \mathrm{~h}: 2 \mathrm{~cm}$.

Fig. 13. Household pottery jugs and mug

1. 2013.14.6.103. $=$ Fig. 11.3.

2. 2013.14.6.104. White, gritty, hard-fired fabric. Md: $9.2 \mathrm{~cm}$, wt: $0.4 \mathrm{~cm}$.

3. 2013.14.6.110. Dark red, fired grey in places. Body lightly ribbed with traces of wheel (ribbing starts at the handle start). Gravelly, hard-fired fabric. Fd: $4 \mathrm{~cm}$, handle: $8 \times 2 \times 0.7 \mathrm{~cm}$.

4. 2013.14.6.112. +2013.12 .1 .10 . Yellowish-white, one of the fragments was fired light grey. There are three rows of incised wavy lines, one above the other, around the vessel's rim, shoulder and belly, separated by grooves. Household pottery of a gritty, hard-fired fabric. Md: $9.5 \mathrm{~cm}, \mathrm{~h}: 28 \mathrm{~cm}$, fd: $10-11 \mathrm{~cm}$, wt: $0.3-0.5 \mathrm{~cm}$.

$$
\text { 5. = Fig. } 11.6 \text {. }
$$

Fig. 14. Household pottery jug, mug/pot

1. 2013.14.20.29. Reddish-brown, with incised wavy line decoration on the shoulder. Well-levigated, hard-fired fabric. Ld: $19.3 \mathrm{~cm}$, neck diameter: $6 \mathrm{~cm}$, wt: $0.4 \mathrm{~cm}$.

2. 2018.1.13.17. Brick-coloured, the carination is grey. A yellowish-brown glaze spot on the outside. Micaceous, medium-hard fired. Md: $12.2 \mathrm{~cm}$, wt: $0.7 \mathrm{~cm}$.

3. 2013.14.12.12. Deformed pot rim. Household pottery of a dark grey, gritty, gravelly, hard-fired fabric. Md: $13 \mathrm{~cm}, w t: 0.5 \mathrm{~cm}$.

4. 2013.14.3.26. Grey, fired black in places. Well-levigated, hard-fired fabric. Md: $12 \mathrm{~cm}$, wt: $0.3 \mathrm{~cm}$.

5. 2013.14.7.3. Reddish-brown, well-levigated, hard-fired household pottery. Md: $13.5 \mathrm{~cm}$, wt: $0.5 \mathrm{~cm}$.

6. 2013.14.5.4. Grey, with a smooth surface. Well-levigated, medium-hard fired. Md: $18 \mathrm{~cm}$, wt: $0.6 \mathrm{~cm}$.

${ }^{185}$ It does not have a catalogue number, as we drew and photographed it in 2000. Later on, it did not resurface during the cataloguing.

Acta Archaeologica Academiae Scientiarum Hungaricae 71, 2020 
Fig. 15. Leányfalu-type mug/pot

1. 2013.14.16.1. Brick-coloured, well-levigated, medium-hard fired fabric. Md: $12.5 \mathrm{~cm}$, wt: $0.5 \mathrm{~cm}$.

2. 2013.14.6.3. Pale red inside and outside, carination grey. Well-levigated, hard-fired. $\mathrm{Md}: 12 \mathrm{~cm}, \mathrm{wt}: 0.5 \mathrm{~cm}$.

3. 2013.14.20.10. Red on the inside, grey on the outside. Thin-walled with lines around the neck and a lightly-ribbed shoulder. Gritty, hard-fired fabric. Md: $10 \mathrm{~cm}$, wt: $0.2 \mathrm{~cm}$.

4-5. 2013.14.22.4. Red, fired grey in places. Neck, shoulder and entire wall ribbed. Household pottery of a gritty, hard-fired fabric. Md: $19.5 \mathrm{~cm}$, wt: $0.4 \mathrm{~cm}$.

6. 2013.14.6.98. Brown, with a furrowed rim and ribbed shoulder. Gritty, hard-fired fabric. Md: $13.5 \mathrm{~cm}, \mathrm{~h}: 6 \mathrm{~cm}, \mathrm{wt}: 0.3 \mathrm{~cm}$.

Fig. 16. Hand-made pottery

1. 2013.14.6.84. Brown, fired black in places and layers. Gravelly, poorly-levigated fabric. Md: $10.5 \mathrm{~cm}, \mathrm{wt}: 0.6 \mathrm{~cm}$.

2. 2013.14.2.42. Reddish-brown, fired black in places, gravelly fabric. The edge of the rim is notched. Md: $14 \mathrm{~cm}$, wt: $0.5 \mathrm{~cm}$.

3-4. 2018.1.19.1. Brown on the outside with blackish-grey spots (the inside, too, is blackish-grey). The rim and base were secondarily fired black. Micaceous fabric with large, colourful pebbles. The traces of the finish are visible on both the inside and outside surface of the vessel. Reconstructed. Md: $16 \mathrm{~cm}, \mathrm{~h}: 38 \mathrm{~cm}, \mathrm{fd}: 14 \mathrm{~cm}$.

\section{REFERENCES}

BIERBAUER 2015

BoCsI 2008

BoCsI 2011

Bocsi-GallinA-Somogyi 2016

BÓNA 1993

BÓNA 2000

BÓNIS 1991

BOTÁR 2011

CIGLENEČKI 1984

CigleneČKi 2000

CONRAD 2007

CVJETIĆANIN 2006

DROBERJAR-KNÁPEK-JARŮŠKOVÁ 2008
= V. BIERBAUER: Ethnische Interpretationsprobleme am Ende des 4. und in der ersten Hälfte des 5. Jahrhunderts. In: Romania Gothica. II.: The Frontier World. Romans, Barbarians and Military Culture. Ed.: T. Vida. Budapest 2015, 365-475.

= Zs. Bocsi: Die Keramik aus zwei spätantiken Siedlungen am Balaton: Ordacsehi Kis-töltés und Zamárdi-Kútvölgyi-dülő, Komitat Somogy, Ungarn. In: Kulturwandel in Mitteleuropa. Langobarden - Awaren - Slawen. Akten der Internationalen Tagung in Bonn vom 25. bis 28. Februar 2008. Hrsg.: J. Bemmann, M. Schmauder. Kolloquien zur Vor- und Frühgeschichte 11. Bonn 2008, 415-430.

= Zs. Bocsı: Néhány ritka és jellemző edényfajta Zamárdi-Kútvölgyi-dülöről [Late Roman settlement segment of Ordacsehi-Csereföld from the $5^{\text {th }}$ century]. In: Hadak útján. A Népvándorlás Kor Kutatóinak XIX. konferenciája, Xántus János Múzeum, Győr, 2008. október 20-22. Eds: Sz. Bíró, P. Tomka. Győr 2011, 11-123.

= Zs. Bocsi-Zs. Gallina-K. Somogyi: Késő római - V. századi településrészlet OrdacsehiCsereföldön [Late Roman $-5^{\text {th }}$ century - settlement segment of Ordacsehi-Csereföld]. In: Beatus homo qui invenit sapientiam. Ünnepi kötet Tomka Péter 75. születésnapjára. Eds: T. Csécs, M. Takács. Győr 2016, 93-132.

= I. BÓNA: A hunok és nagykirályaik (Das Hunnenreich). Budapest 1993.

= I. BóNA: A Pentelei Öreghegy és Intercisa erődjének története a későrómai időktől a török kiüzéséig (Die Geschichte von Öreghegy in Pentele und des Kastellum in Intercisa von der spätrömischen Zeit bis zur Vertreibung der Türken). In: Dunaújváros története (Die Geschichte von Dunaújváros). Hrsg.: F. Erdős, Zs. Pongrácz. Dunaújváros 2000, 69-78.

= É. BóNIs: Glasierte Keramik der Spätrömerzeit aus Tokod. ActaArchHung 43 (1991) 87-150.

= I. BotÁr: A Marosszentanna-Csernyahov kultúra emlékei a Csíki-medencében (Archaeological finds of the Sântana de Mureş-Cerneahov (4th century) culture in the Csík-Basin). In: Erdély és kapcsolatai a kora népvándorlás korában. Molnár István Múzeum kiadványai 3. Hrsg.: Zs. Körösföi. Székelykeresztúr 2010-2011, 15-38.

= S. CiglenEČKI: Die Keramik des 4-6. Jh. von Gradec, Tinje und Korinjski hrib Slowenien. ArchA 68 (1984) 313-328.

= S. CigleneČKI: Beziehung des Materials vom Tinje zum zeitgenössischen Vorkommen der Grobkeramik in Slowenien und im weiteren Ostalpenraum. In: S. Ciglenečki: Tinje oberhalb von Loka pri Žusmu: Spätantike und frühmittelalterliche Siedlung. Opera Instituti Archaeologici Sloveniae 4. Ljubljana 2000, 69-138.

= S. CoNRAD: Die Gefäßkeramik. In: Iatrus-Krivina: Spätantike Befestigung und frühmittelalterliche Siedlung an der unteren Donau. 6.: Ergebnisse der Ausgrabungen 1992-2000. Hrsg.: G. v. Bülow, B. Böttger, S. Conrad [u.a.]. Limesforschungen 28. Mainz am Rhein 2007, 209-265.

= T. Cvjetićanin: Late Roman Glazed Pottery. Glazed pottery from Moesia Prima, Dacia Ripensis, Dacia Mediterranea and Dardania. Archaeological monographies 19. Belgrad 2006.

= E. DROBERJAR-R. KNÁPEK-Z. JARŮŠKOVÁ: The importance of finds from the Migration Period in Malá Haná (Moravia). K významu nálezů z doby stěhování národů na Malé Hané (Morava). PV 60/1 (2019) 109-141. 
ELSCHEK 2017

FRIESINGER-KERCHLER 1981

GABLER 2016

GASSNER 2000

GATTRINGER-GRÜNEWALD 1981

GiNDELE-ISTVÁNOVITS 2009

GRÓF 2012

GRÓF 2016

GRÓF-GRÓH 1995

GRÓF-GróH-MRÁv 2001-2002

GRÓH 2000

GRÓH 2006

GROH-SEDLMAYER 2002

GROH-SEDLMAYER 2013

GRÜNEWALD 1979

HÁRSHEGYI-OTTOMÁNYI 2013

HEGEWISCH 2011

HoRVÁTH 2011a

HORVÁTH 2011b

HORVÁTH 2016

ISTVÁNOVITS-KULCSÁR 2005

JELINČIĆ 2015

JEREMIĆ 2012
= K. ElscheK: Bratislava-Dúbravka im 1. bis 4. Jahrhundert n. Chr. Germanischer Fürstensitz mit römischen Bauten und die germanische Besiedlung. Archaeologica Slovaca monographiae. Studia 29. Nitra 2017.

= H. FRIESINGER-H. KERCHLER: Töpferofen der Völkerwanderungszeit in Niederösterreich. Ein Beitrag zur völkerwanderungszeitlichen Keramik (2. Hälfte 4.- 6. Jahrhundert n. Chr.) in Niederösterreich, Oberösterreich und dem Burgenland. ArchA 65 (1981) 193-266.

= D. GABLER: Terra Sigillaten in der Siedlung Visegrád-Lepence. ZSNM Archeologia Suppl. 11. Bratislava 2016, 131-146.

= V. GASSNER: Die Keramik mit Ausnahme der Terra Sigillata. In: Das Kastell Mautern - Favianis Hrsg.: V. Gassner, S. Groh, S. Jilek, A. Kaltenberger, W. Pietsch, R. Sauer, H. Stieglitz, H. Zabehlicky. RLiÖ 39. Wien 2000, 184-314.

= A. GATTRINGER-M. GRÜNEWALD: Zur Typologie der „Horreumkeramik”. BVbl 46 (1981) 199-210.

= R. GINDELE-E. IsTVÁNOVITS: Die römerzeitliche Siedlung von Csengersima-Petea. Satu Mare 2009.

= P. GRóF: Népvándorlás kori vonatkozások egy késő római erőd és temető feltárásának kapcsán (Völkerwanderungszeitliche Bezüge im Zusammenhang mit der Erschlissung einer spätrömischen Festung und Gräberfeldes). JAMÉ (1992) 129-144.

= P. GRÓF: Hunkori aranytárgy a visegrád-gizellamajori késő római erődből (A gold finger-ring of the Hun period from the late Roman fort at Visegrád-Gizellamajor). In: Népek és kultúrák a Kárpátmedencében. Tanulmányok Mesterházy Károly tiszteletére. Szerk.: L. Kovács, L. Révész. Budapest 2016, 137-146.

= P. GRÓF-D. GRÓH: Római építészeti emlékek Visegrád térségében (The Roman monuments of Visegrád). Müemlékvédelem 39 (1995) 61-68.

= P. GRÓF-D. GRÓH-Zs. MRÁv: Sírépítményből átalakított küszöbkő a Visegrád-Gizella-majori későrómai erődből (Aus einem Grabbauelement umgeänderter Schwellenstein aus dem spätrömischen Kastell von Visegrád). FolArch 49-50 (2001-2002) 247-262.

= D. GRóH: A Visegrád-Gizellamajori római erőd rétegviszonyainak építéstörténeti vonatkozásai (Die baugeschichtlichen Beziehungen der schichtenreihende der römischen Festung von VisegrádGizellamajor). In: Hadak útján. A Népvándorlás Kor Fiatal Kutatóinak X. konferenciája, Domaszék, 1999. szeptember 27-30. Eds: L. Bende, G. Lörinczy, Cs. Szalontai. Szeged 2000, 27-33.

= D. GRóH: A Visegrád-Gizellamajori erőd és a Dunakanyar szerepe a késő római védelmi politikában. [PhD dissertation, The role of the Visegrád-Gizellamajor fort and the Danube Band in Late Roman defence policy]. Budapest, Eötvös Loránd Tudományegyetem, Bölcsészettudományi Kar 2006.

= S. GROH-H. SedLMAYER: Forschungen im Kastell Mautern-Favianis. Die Grabungen der Jahre 1996 und 1997. RLiÖ 42. Wien 2002.

= S. GROH-H. SEDLMAYER: Contextual archaeology: The late antique fort and vicus Favianis/Mautern. Methods and results. In: Field Methods and Post-Excavation Techniques in Late Antique Archaeology. Eds: L. Lavan, M. Mulryan. Late antique archaeology 9. Leiden 2013, 483-509.

= M. GRÜNEWALD: Die Gefäßkeramik des Legionslagers von Carnuntum. RLiÖ 29. Wien 1979.

= P. HÁRSHEGYI-K. OTTOMÁNYI: Imported and local pottery in late Roman Pannonia. In: Local Economies? Production and Exchange of Inland Regions in Late Antiquity. Late antique archaeology 10. Ed.: L. Lavan. Leiden-Boston 2013, 471-528.

= M. HegEwisch: Zur Drehscheibenkeramik im Westen der Germania Magna, Anfänge, Weiterentwicklung und Verbreitung. In: Drehscheibentöpferei im Barbaricum. Hrsg.: J. Bemmann, M. Hegewisch, M. Meyer, M. Schmauder. Bonn 2011, 119-174.

= F. HoRvÁtH: Das spätantike Keramikspektrum in Keszthely-Fenékpuszta - erste Ergebnisse. In: Keszthely-Fenékpuszta im Kontext spätantiker Kontinuitätsforschung zwischen Noricum und Moesia. Hrsg.: O. Heinrich-Tamáska. Castellum Pannonicum Pelsonense 2. Budapest-LeipzigKeszthely-Rahden 2011, 597-652.

= F. HoRvÁTH: Keramik. In: F. Teichner: Die Gräberfelder von Intercisa. 2.: Die Altfunde der Museumssammlungen in Berlin, Mainz und Wien. Bestandskatalog 11. Berlin 2011, 193-229.

= F. HoRVÁTH: Eine besondere Gruppe der spätrömischen Keramik mit polierter Oberfläche - Beiträge zu den römisch-barbarischen Beziehungen. Antaeus 34 (2016) 41-104.

= E. IsTVÁNOVITS-V. KulcSÁR: Gritty pots, a characteristic type of Roman provincial import and Barbarian pottery on the Barbarian settlements of the Great Hungarian Plan. In: Limes XIX. Proceedings of the XIXth International Congress of Roman Frontier Studies. Ed.: Zs. Visy. Pécs 2005, 987-997.

= K. Jelinčıć VučKović: Rimsko selo u Provinciji Gornjoj Pannoniji: Virovitica Kiškorija Jug Roman Village in the Province of Upper Pannonia: Virovitica Kiškorija South. MIA 7. Zagreb 2015. = G. JEREMIĆ: Late Roman and Early Byzantine pottery from Saldum. RCRF Acta 42 (2012) 81-88. 
KELEMEN 2012

KovÁCs 2004

KovÁCS 2016

KULCSÁR-MÉRAI 2011

LÁNYI 1972

LÁNYI 1981

MASEK 2011

MASEK 2013

MASEK 2018

MiKLÓSITY SzŐKE 2008

NÁDORFI 1992

OPREANU 2013

OTTOMÁNYI 1982

OTTOMÁNYI 1989

OTTOMÁNYI 1991

OTTOMÁNYI 1996

OTTOMÁNYI 1999

OTTOMÁNYI 2004

OTTOMÁNYI 2008

OTTOMÁNYi 2009

OTTOMÁNYI 2011

OTTOMÁNYI 2012

OTTOMÁNYI 2015 a
= M. H. KelEmen: Adatok egy új római objektumról Tokodon [Data of a new Roman settlement feature at Tokod]. In: Laudator temporis actis. Tanulmányok Horváth István 70 éves születésnapjára. Eds: E. Tóth, E. Tari. Esztergom-Budapest 2010 [2012] 69-93.

= P. KovÁcs: Hunkori sír Százhalombattán (A grave from the Hun-Period at Százhalombatta). ComArchHung 2004, 123-150.

$=$ P. KovÁcs: Notes on the Pannonian foederati. In: Les auxiliaires de l'armée romaine. Des alliés aux fédérés. Ed.: C. Wolff, P. Faure. Lyon 2016, 575-602.

= V. KULCSÁR-D. MÉRAI: Roman or Barbarian? Provincial models in a Sarmatian pottery. Center on the Danube frontier. In: The Roman Empire and Beyond: Archaeological and Historical Research on the Romans and Native Cultures in Central Europe. Eds: E. De Sena, H. Dobrzanska. BAR IntSer 2236. Oxford 2011, 61-80.

= V. LÁNYI: Die spätantiken Gräberfelder von Pannonien. ActaArchHung 24 (1972) 53-213.

= V. LÁNYI: Die graue spätrömische Keramik von Tokod. In: Die spätrömische Festung und das Gräberfeld von Tokod. Hrsg.: A. Mócsy. Budapest 1981, 73-120.

= Zs. MASEK: Adatok a Marosszentanna-Csernyahov-kultúra és az alföldi késő szarmata - hun kori kerámiaanyag kapcsolataihoz (Angaben zu den Beziehungen der Sîntana de Mureš-ČernjachovKultur und des spätsarmatisch-hunnenzeitlichen Keramikmaterials auf dem Ungarischen Tiefebene). In: Erdély és kapcsolatai a kora népvándorlás korában. Hrsg.: Zs. Körösföi. Molnár István Múzeum kiadványai 3. Székelykeresztúr 2011, 249-292.

$=$ Zs. MASEK: Die kulturellen Beziehungen der hunnenzeitlichen Eliten im östlichen Mitteldonaugebiet am Beispiel der einglättverzierten Drehscheibenkeramik. In: Macht des Goldes, Gold der Macht. Herrschafts- und Jenseitsrepresentation zwischen Antike und Frühmittelelter im mittleren Donauraum. Akten des 23. Internationalen Symposiums der Grundprobleme der frühgeschichtlichen Entwicklung im mittleren Donauraum, Tengelic, 16.-19.11.2011. Hrsg.: M. Hardt, O. Heinrich-Tamáska. Forschungen zu Spätantike und Mittelalter 2. Weinstadt 2013, 229-250.

= Zs. MASEK: A Közép-Tisza-vidék településtörténete a Kr. u. 4-6. században Rákóczifalva-Bagiföldek 5-8-8A. lelőhely értékelése alapján. $\mathrm{PhD}$ disszertáció [Settlement history of the MiddleTisza-Region in the $4^{\text {th }}-6^{\text {th }}$ century AD, as based of the evaluation of the findspot no. 5-8-8A at A Rákóczifalva-Bagi földek]. Eötvös Lóránd Tudományegyetem, Bölcsészettudományi Kar. Budapest 2018

= M. MiKLósiTy SzŐKE: Késő római mázas kerámia Brigetio legiotáborából (Spätrömische glasierte Keramik aus dem Legionslager von Brigetio). KEMMK 12 (2006-2008) 159-196.

= G. NÁDORFI: Glasierte Keramik in spätrömischen Gräberfeldern Pannoniens. In: Glasierte Keramik in Pannonien. Ausstellungskatalog. Hrsg.: Zs. Bánki, V. Cserményi. Székesfehérvár 1992, 45-51.

= C. H. OpREANU: Burnished pottery from the settlement at Suceag (County of Cluj, Romania). Evolution, chronology and cultural interferences. EphNapoc 23 (2013) 51-78.

= K. ОттомÁNYI: Fragen der spätrömischen eingeglätteten Keramik in Pannonien. DissArch II.10. Budapest 1982. [Univ. Diss]

= K. OtтомÁNYi: Late Roman pottery. In: The Roman Fort at Ács-Vaspuszta (Hungary) and the Danubian Limes. Ed: D. Gabler. BAR IntSer 531. Oxford 1989, 318-386, 492-570.

= K. OTTOMÁNYI: Későrómai kerámia a leányfalui őrtoronyból (Keramik aus dem Burgus von Leányfalu). StComit 22 (1991) 5-144.

= K. Оттоми́nYı: Eine Töpferwerkstatt der spätrömische Keramik mit Glättverzierung von Pilismarót-Malompatak. ActaArchHung 48 (1996) 71-134

= K. ОттомánYi: Late Roman pottery in the Dunabogdány camp. In: Antaeus 24 (1999) 333-373, $726-738$.

= K. ОттомÁnYi: A Budakalász-Luppacsárdai örtorony késő római kerámiája (Die spätrömischen Keramiken des Wachtturmes von Budakalász-Luppacsárda). StComit 28 (2004) 265-295.

= K. ОттомÁNYI: Késő római - kora népvándorlás kori település részlet Biatorbágyról (Ein Siedlungsteil von Biatorbágy aus der späten Römer- und frühen Völkerwanderungszeit). ArchÉrt 133 (2008) 133-197.

= K. Оттомányi: Eingeglättete Gefässe aus der letzten Periode der Siedlung von Budaörs. In: Ex officina... Studia in honorem Dénes Gabler. Hrsg.: Sz. Bíró. Győr 2009, 411-442.

= K. OтTомÁNYI: Késő római mázas kerámia a budaörsi telepen (Late Roman Age glazed pottery in the Budaörs settlement). Arrabona 49/1 (2011) 263-290.

= K. OTTOMÁNYI: A Visegrád-Gizellamajori erőd Ny/I. helyiségének késő római kerámiája (Veränderungen des Töpferhandwerks in der ersten Hälfte 5. Jhs. auf Grund des Keramik von Befestigung Visegrád-Gizellamajor). In: FiRkák II. Fiatal Római Koros Kutatók II. Konferenciakötete. Hrsg.: Sz. Bíró, P. Vámos. Győr 2012, 383-418.

= K. ОттомÁNYI: A Visegrád-Gizellamajorban feltárt késő római kiserőd keltezése a kerámia anyag alapján (Déli épületszárny) [Dating the Visegrád-Gizellamajor Late Roman fortress, based on its 
OTTOMÁNYI 2015b

OTTOMÁNYI 2018a

OTTOMÁNYI 2018b

OTTOMÁNYI 2018c

OTTOMÁNYI-SOSZTARITS 1998

PALÁGYI 2004

Petrauskas 2011

POLLAK 1980

RODRIGUEZ 1997

QUAST 2008

SOÓs-BÁRÁNY-KÖHLER-PUSZTAI 2017

SOPRONI 1985

STADLER et al. 2008

STUPPNER 2008

ŠVAŇA 2011

SZŐNYI 1984

TEJRAL 1982

TEJRAL 1985

TEJRAL 1988

ToMKA 2004

Tóтн 2005

UBL 1986

VADAY 1988-1989 pottery material - southern wing of the building]. Archaeologia - Altum Castrum online magazin. 2015 március, 1-93. http://archeologia.hu/ottomanyi-visegrad-gizellamajor-keramia-anyaga

= K. ОттомÁnYı: Veränderungen des Töpferhandwerks in der ersten Hälfte 5. Jhs. anhand der Keramik der Befestigung Visegrád-Gizellamajor. In: Romania Gothica. 2.: The Frontier World. Romans, Barbarians and Military Culture. Ed.: T. Vida. Budapest 2015, 691-740.

= K. OттомÁNYI: A Visegrád-Gizellamajorban feltárt kiserőd udvarának késő római kerámiája (Late Roman pottery from the courtyard of the fortress found in Visegrád-Gizellamajor). StComit 36 (2018) 94-132.

= K. OттомÁNYI: Késő római kerámia a visegrád-gizellamajori erőd északnyugati saroktornyából (Late Roman pottery from the north western tower of the Visegrád-Gizellamajor fort). In: „Hadak útján” A népvándorláskor fiatal kutatóinak XXVII. konferenciája, Debrecen 2017. október 27-28. Eds: P. Forisek, Á. Szabó, J. Szakács. Debrecen 2018, 128-152.

= K. ОттомÁNYI: Késő római kerámia Visegrád-Gizellamajor erődjének Északi I. helyiségében (Late Roman pottery from the North I. chamber of the fortress of Visegrád-Gizellamajor). Tisicum 26 (2018) 119-144.

= K. OTtOMÁnYI-O. SoszTARITS: Spätrömische Töpferofen in südlichen Stadteil von Savaria. Savaria 23/3 (1996-97) 1998, 145-216.

= Sz. PALÁGYI: Veszprém megyei leletmentések publikálatlan római kemencéi (Unpublished Roman Period kilns from Veszprém County find rescues). VMMK 23 (2004) 49-72.

$=$ O. V. Petrauskas: Scheibengedrehte Keramik als chronologischer Anzeiger nach den Materialien des Gräberfeldes der Černjachov-Kultur bei Velikaja Bugaevka, Kyivs'kaja obl., Ukraine. In: Drehscheibentöpferei im Barbaricum. Hrsg.: J. Bemmann, M. Hegewisch, M. Meyer, M. Schmauder. Bonn 2011, 399-416.

$=$ M. PollaK: Die germanischen Bodenfunde des I-IV. Jahrhunderts n. Chr. im nördlichen Niederösterreich. Wien 1980.

= H. RoDRIGUEZ: Die Zeit vor und nach der Schlacht am Fluvius Frigidus (394 n. Chr.) im Spiegel der südostalpinen Gebrauchskeramik. AV 48 (1997) 153-178.

= D. QuAST: Der Runde Berg bei Urach. Die alamannische Besiedlung im 4. und 5. Jahrhundert. In: Höhensiedlungen zwischen Antike und Mittelalter von den Ardennen bis zur Adria. Hrsg.: H. Steuer, V. Bierbrauer. RGA Ergänzundsband 58. Berlin-New York 2008, 261-322.

= E. Soós-A. BÁRÁNY-K. KöHLER-T. PusZTAI: Settlement and graves from Hernádvécse (NE-Hungary) from in 5th century and the relation between living space and burial place in the Hunnic Period. HOMÉ 56 (2017) 49-98.

= S. Soproni: Die letzten Jahrzehnte des pannonischen Limes. München 1985

= P. Stadler-H. Friesinger-W. Kutschera-E. Lauermann-Zs. RácZ-J. Tejral-E.-M. Wild-T. ZEMAN: Kann man die Zuordnung zu den verschiedenen (ethnischen) Gruppen der Völkerwanderungszeit mittels naturwissenschaftlicher Datierungsmethoden verbessern? In: Hunnen zwischen Asien und Europa. Aktuelle Forschungen zur Archäologie und Kultur der Hunnen. Langenweissbach 2008, 157-183.

= A. STUPPNER: Bemerkungen zu den vorlangobardischen Funden im mittleren Donauraum. In: Kulturwandel in Mitteleuropa. Langobarden - Awaren - Slawen. Akten der Internationalen Tagung in Bonn vom 25. bis 28. Februar 2008. Hrsg.: J. Bemmann, M. Schmauder. Kolloquien zur Vor- und Frühgeschichte 11. Bonn 2008, 286-297.

$=\mathrm{K}$. ŠVAŇA: Post-Valentinian and early 5th century finds of late Roman glazed pottery from the auxiliary fort at Iža, bridgehead of Brigetio. Anodos. Studies of the Ancient World 11 (2011) 269-281.

= E. SZŐNYI: Die Keramik des 4. und 5. Jahrhunderts n. Chr. aus Arrabona. ArchA 68 (1984) 345-350.

$=$ J. TEJRAL: Morava na Sklonku antiky [Moravia at the End of Antiquity]. Monumenta archaeologica 19. Praha 1982.

= J. Tejral: Spätrömische und völkerwanderungszeitliche Drehscheibenkeramik in Mähren. ArchA 69 (1985) 105-140.

= J. TEJRAL: Zur Chronologie der frühen Völkerwanderungszeit im mittleren Donauraum. ArchA 72 (1988) 223-304.

= P. TomKA: Kulturwechsel der spätantiken Bevölkerung eines Auxiliarkastells: Fallbeispiel Arrabona. In: Zentrum und Peripherie - Gesellschaftliche Phänomene in der Frühgeschichte. Hrsg.: H. Friesiger, A. Stuppner. Wien 2004, 389-409.

= Е. То́тн: Karpen in der Provinz Valeria. Zur Frage der spätrömischen eingeglätteten Keramik in Transdanubien. ComArchHung 2005, 363-391.

$=$ H. UBL: Tulln, Zeiselmauer, Klosterneuburg. Neue Forschungsergebnisse zu drei Hilfstruppenlagern im norischpannonischen Grenzbereich des österreichischen Limesabschnitts. RÖ 15-16 (1986) 293-332.

= A. VADAY: Die sarmatischen Denkmäler des Komitats Szolnok. Antaeus 17-18. Budapest 1989. 
VAŠIĆ 1982-1983

VIDA 2011

VISY 2003
= M. VAšIĆ: Čezava - Castrum Novae. Starinar 32-33 (1982-1983) 91-122.

= T. VIDA: Die Zeit zwischen dem 4. und dem 6. Jahrhundert im mittleren Donauraum aus archäologischer Sicht. In: Römische Legionslager in den Rhein- und Donauprovinzen - Nuclei spätantikfrühmittelalterlichen Lebens? Publ.: M. Konrad, Ch. Witschel. Abhandlungen/Bayerische Akademie der Wissenschaften, Philosophisch-historische Klasse N.F. 138. München 2011.

$=$ Zs. VISY (ed.): The Roman Army in Pannonia. AnArchaeological Guide of the Ripa Pannonica. Pécs 2003.

Open Access. This is an open-access article distributed under the terms of the Creative Commons Attribution 4.0 International License (https:// creativecommons.org/licenses/by/4.0), which permits unrestricted use, distribution, and reproduction in any medium, provided the original author and source are credited, a link to the CC License is provided, and changes - if any - are indicated. (SID_1) 
